\title{
The threatened brain : magnetic resonance imaging studies into fear and panic
}

Citation for published version (APA):

Goossens, L. (2009). The threatened brain : magnetic resonance imaging studies into fear and panic. [Doctoral Thesis, Maastricht University]. Maastricht University. https://doi.org/10.26481/dis.20090605ig

Document status and date:

Published: 01/01/2009

DOI:

10.26481/dis.20090605lg

Document Version:

Publisher's PDF, also known as Version of record

\section{Please check the document version of this publication:}

- A submitted manuscript is the version of the article upon submission and before peer-review. There can be important differences between the submitted version and the official published version of record.

People interested in the research are advised to contact the author for the final version of the publication, or visit the DOI to the publisher's website.

- The final author version and the galley proof are versions of the publication after peer review.

- The final published version features the final layout of the paper including the volume, issue and page numbers.

Link to publication

\footnotetext{
General rights rights.

- You may freely distribute the URL identifying the publication in the public portal. please follow below link for the End User Agreement:

www.umlib.nl/taverne-license

Take down policy

If you believe that this document breaches copyright please contact us at:

repository@maastrichtuniversity.nl

providing details and we will investigate your claim.
}

Copyright and moral rights for the publications made accessible in the public portal are retained by the authors and/or other copyright owners and it is a condition of accessing publications that users recognise and abide by the legal requirements associated with these

- Users may download and print one copy of any publication from the public portal for the purpose of private study or research.

- You may not further distribute the material or use it for any profit-making activity or commercial gain

If the publication is distributed under the terms of Article $25 \mathrm{fa}$ of the Dutch Copyright Act, indicated by the "Taverne" license above, 


\section{The Threatened Brain}

Magnetic Resonance I maging Studies into Fear and Panic 
The threatened Brain. Magnetic Resonance Imaging Studies into Fear and Panic Liesbet Goossens

ISBN: 978-90-9024302-3

Cover design by Liesbet Goossens

Printed by Van Gossum Printing bvba, Tessenderlo (België)

(c) Liesbet Goossens, Maastricht 2009 


\title{
The Threatened Brain \\ Magnetic Resonance I maging Studies into Fear and Panic
}

\author{
PROEFSCHRIFT \\ ter verkrijging van de graad van doctor aan de Universiteit Maastricht, \\ op gezag van de Rector Magnificus, Prof mr. G.P.M.F. Mols \\ volgens het besluit van het College van Decanen, \\ in het openbaar te verdedigen \\ op vrijdag 5 juni 2009 om 12.00 uur \\ door
}

Liesbet Goossens 


\section{Promotor}

Prof. dr. E.J.L. Griez

\section{Copromotores}

Dr. K.R.J. Schruers

Dr. S. Sunaert, Katholieke Universiteit Leuven

\section{Beoordelingscommissie}

Prof. dr. F.R.J. Verhey (voorzitter)

Dr. J. Prickaerts

Prof. dr. H.W.M. Steinbusch

Prof. dr. H.B.M. Uylings

Prof. dr. D.J. Veltman, Vrije Universiteit Amsterdam 


\section{CONTENTS}

Chapter Title

Page

I. Introduction

7

II. Visual presentation of phobic stimuli: amygdala activation via an extrageniculostriate pathway?

III. Amygdala hyperfunction in phobic fear normalizes after exposure

IV. Evidence for changes in brain connectivity following single session behavioural therapy

V. Selective processing of social stimuli in the superficial amygdala

VI. Triggering vital alarms: $7 \% \mathrm{CO} 2$ administration in panic disorder patients and healthy controls (pilot data)

VII. Summary and Concluding Remarks 

CHAPTER I

Introduction

7 


\section{Anxiety, fear and panic: terminology}

Distinction between the concepts of anxiety, fear and panic has often been unclear in the past. A clear example of this is found in current clinical classification of psychiatric disorders such as DSM IV. It groups disorders characterized by anxiety, phobia or panic in a single category, labelled "anxiety disorders". Thus, it is suggested that anxiety, fear and panic are variations of the same. Evidence from pharmacological and ethological studies, however, rather suggests the opposite.

Some drugs, such as most benzodiazepines, alleviate generalized as well as social anxiety but have no effect on panic or phobia at the same dosage. Other drugs, such as clomipramine, do alleviate panic but are relatively less efficacious in treating social or generalized anxiety. No drug produces a specific limited effect, but the variation in relative effectiveness across different aspects of DSM IV anxiety disorders argues in favour of a distinction between anxiety, fear and panic (McNaughton and Zangrossi, 2008).

Ethological experiments, on the other hand, use the defensive response of an animal or a human towards a threat to dissect anxiety from fear. Threats can be represented by predators, attack by conspecifics or dangerous features of the environment. It appears that the actual presence of a predator elicits behaviour that can be identified as fear. The specific type of behaviour is influenced by the distance to the threat (defensive distance): respectively flight, freezing or defensive attack with decreasing distance. The reaction to the potential, uncertain presence of a threat is named anxiety. Behaviour includes increased vigilance and risk assessment (Blanchard and Blanchard, 2008).

McNaughton and Corr have proposed a model that integrates these elements, based on the work by Gray (Gray and McNaughton, 2000; McNaughton and Corr, 2004). It is based on two behavioral dimensions: defensive distance and defensive direction. Fear and anxiety are seen as distinct, regarding defensive direction. Fear operates when leaving a dangerous situation (active avoidance), anxiety when entering it (risk assessment, approach behavior). The theory views the eventual defensive behavior as resulting from the superimposition of defensive distance on defensive direction (Fig. 1). Defensive distance controls the type of defensive behavior observed. Small defensive distances result in explosive attack, intermediate ones in freezing and flight and great distances result in normal, non-defensive behavior. 


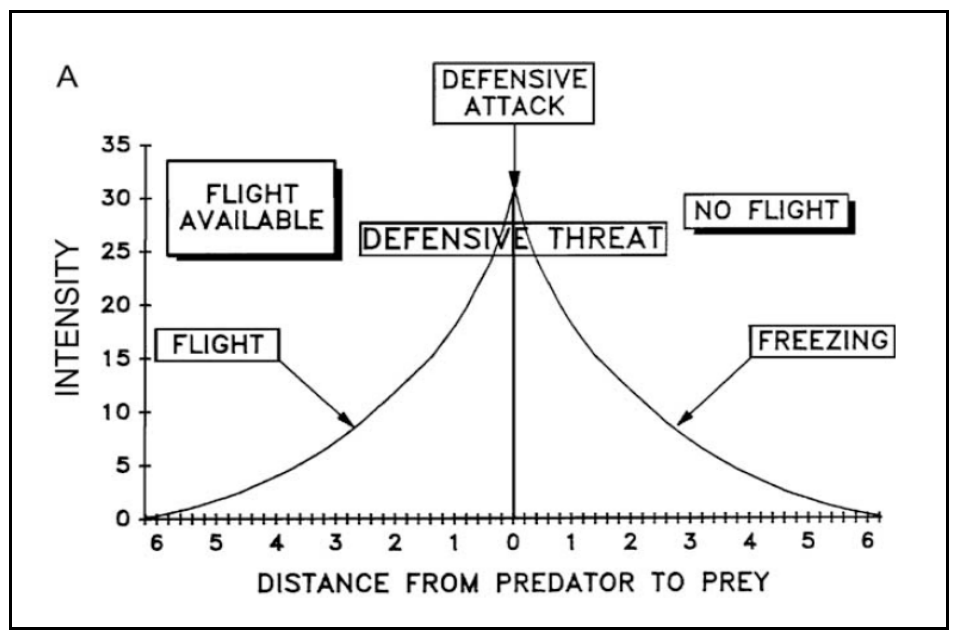

Fig. 1: The relationship between defensive distance and behaviour for defensive avoidance (Blanchard and Blanchard, 1990)

Defensive behaviours can become maladaptive, for example in case of elicitation of the system by a non-threatening stimulus or insufficiently intense threat. It is suspected that this maladaptiveness is embedded in most anxiety disorders. Extrapolating the theory to clinical settings, the internal state at very small distances would be labeled "panic", corresponding to the most proximal defensive distance with the threat coming from within the body itself. Intermediate defensive distances can be equated with phobic avoidance.

\section{Neural mapping of the defensive behaviour hierarchy}

In a next conceptual step, the hierarchy of defensive behaviours of increasing complexity can be mapped onto a neural hierarchy from caudal structures in the brainstem to rostral structures, including the prefrontal cortex (Fig. 2).

At the most basic level of the brain is the periaqueductal grey (PAG). It is associated with undirected escape and, in humans, panic. The medial hypothalamus $(\mathrm{MH})$ is situated directly above and controls directed escape/phobic escape. These conclusions are mainly drawn from results of stimulation studies in small animals (Graeff, 1994). Above the PAG and the $\mathrm{MH}$, the amygdala is thought to control active avoidance/phobic avoidance. Clues for the involvement of this structure came from 'fear-potentiated startle' and 'fear conditioning' studies (Davis, 1992; Davis, 1997; LeDoux, 1994). The amygdala has also an important role in autonomic arousal. It 
deals with threatening stimuli that are tightly linked in time with the actual threat.

One level higher, the anterior cingulate cortex (ACC) governs more complex avoidance behaviour, initiated by stimuli that are less tightly linked with the threat and require a greater degree of anticipation (Gray and McNaughton, 2000). The cingulate cortex can be divided in an anterior and a posterior part. The anterior part is involved in the resolution of conflicts and possibly also in selection for action. Different parts of it may be involved in more cognitive and more emotional processing respectively (Bush et al., 2000). The posterior cingulate has a role in passive avoidance but may also be involved in defensive approach and avoidance conflicts. The cingulate cortex has been proposed to act as the "limbic motor cortex" (Craig, 2003).

The more cortical a structure, the more complex its role and the larger the array of behavior it controls. At the pinnacle sits the prefrontal cortex, to which is assigned those expectations of threat that involve the most complex assessment and the greatest distance in the future.

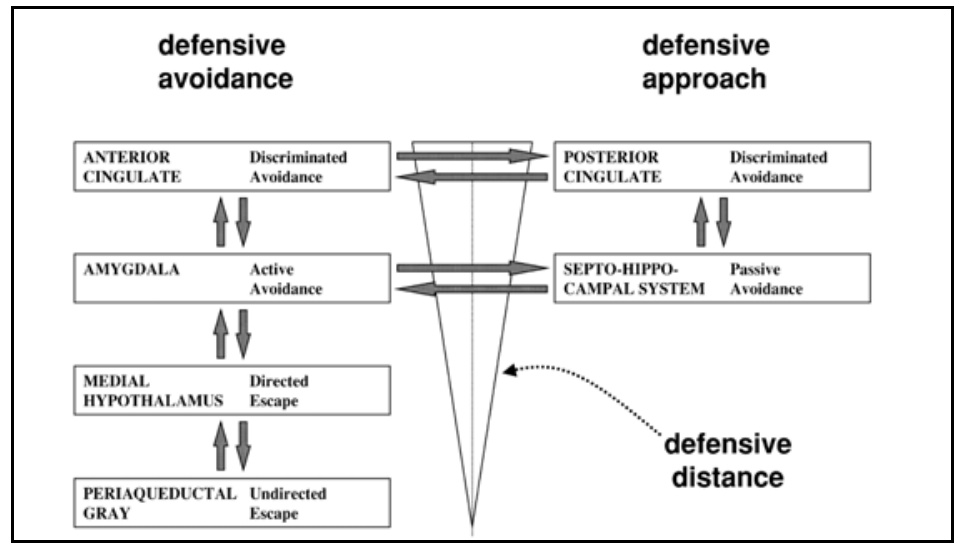

Fig. 2: Mapping of defensive behaviour to a neural hierarchy (McNaughton and Gray, 2000)

Somewhat aside from this, and not covered in the model by McNaughton and Corr is the insula. Craig $(2003,2004)$ convincingly shows that the insula acts as the limbic sensory cortex. It is the brain region where interoceptive signals from the body are represented. In humans, re-representations from this interoceptive cortex lead to a meta-representation of the state of the body in the right anterior insula that is associated with the subjective awareness of the "feeling self". Signals about the internal state of the body and the conscious awareness of these sensations are of eminent importance in emotions such as anxiety and fear but also disgust. In the case of panic 
disorder, the conscious awareness of the bodily signs of a panic attack typically leads to anticipatory anxiety for new attacks and phobic avoidance of situations that are linked to the attacks.

\section{Learning of fear and safety}

The previous paragraph primarily concerned the way the brain deals with actual threatening situations. However, besides stimuli that elicit fear innately, other stimuli can acquire the capacity to elicit fear. Classical or Pavlovian fear conditioning involves the generation of defensive reactions to a stimulus that predicts an aversive consequence. In a typical conditioning experiment, an animal or human is presented with an emotionally neutral stimulus (CS) that is paired in time with an aversive unconditioned stimulus (US). Mostly auditory or visually presented stimuli are used as CS, while the US is often a mild electrical shock. As mentioned in the former paragraph, studying the processing of learned fear in these kinds of studies contribute to our knowledge on the defense circuitry. Studies into fear learning mainly used classical and instrumental conditioning paradigms to model fear reactions and action patterns respectively.

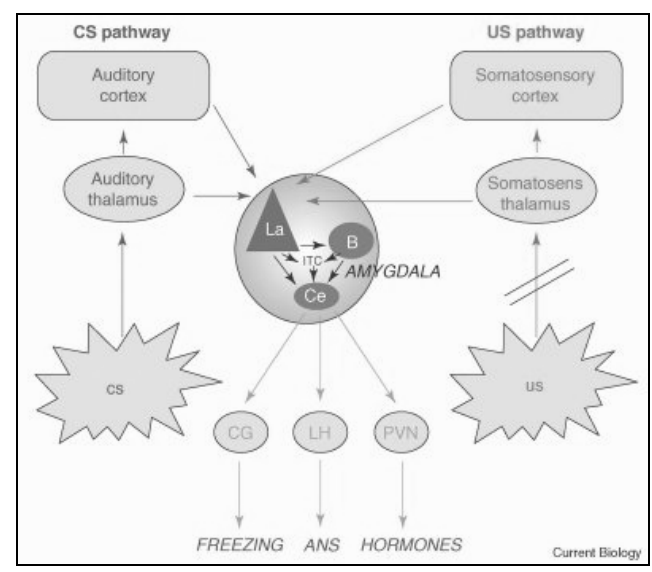

Fig. 3: Auditory fear conditioning pathways (LeDoux, 2007)

The neural circuitry for classical fear conditioning using auditory CS has been particularly well studied (Fig.3). It has lead to the conclusion that the amygdala is critical for the learning, storage and expression of fear conditioning (Cain and LeDoux, 2008). One has to bear in mind that the amygdala is not a single nucleus but rather an almond shaped cluster of 
nuclei in the temporal lobe. Of these, three have been shown to be of particular importance in fear conditioning: the lateral nucleus (LA), the central nucleus (CE) and the basal nucleus (B).

The same Neurons in the LA receive auditory (CS) and somatosensory shock (US) inputs from the thalamus. They connect to $C E$, both directly and indirectly via $B$. The LA is essential for acquisition as well as retention of fear conditioning. The $\mathrm{CE}$, on the other hand, is mainly important for the expression of fear conditioning. It is an "output" nucleus that projects to the hypothalamus and the brainstem which are responsible for the motor, autonomic and endocrine aspects of the fear response. The particular role of $B$ in classical conditioning is less clear-cut but at the least it has a part in fear expression (Cain and LeDoux, 2008; LeDoux, 2000).

Instrumental fear conditioning usually occurs as a part of an (active) avoidance learning protocol. In this case, an animal is presented with a pairing of a tone and an electric shock on one side of a chamber that is divided into two compartments. When the animal moves to the other side, the tone stops and the shock is prevented. Avoidance learning therefore consists of two parts: first learning of the association between the tone and the shock and then learning to escape the tone and prevent shock delivery. "Escape from fear" (EFF) learning (Mowrer 1947) has been proposed to explain how classical and instrumental conditioning interact to mediate active avoidance. It is proposed that first classical conditioning establishes fear of the CS. Subsequently, active responding is reinforced by the fear reduction that comes along with termination of the CS (Cain and LeDoux, 2008).

The amygdala plays an essential role in the neural circuitry of active avoidance learning. Recent studies into the specific role of amygdala subnuclei show that, as in classical conditioning, LA is important for the acquisition of CS-US associations and CE for mediating the output. In avoidance learning, B appears to have a specific role in using the conditioned incentive information to guide goal-directed action learning. This puts it in an ideal position to link brain processing of emotional learning with that of subsequent motivation to direct the organism away from aversive stimuli and towards safety or reward. Indeed, recent evidence shows that $B$ projects to the nucleus accumbens, where dopamine is released (Pezze and Feldon, 2004). Furthermore, the CE also projects to the accumbens, via the ventral tegmental area, thereby putatively also stimulating dopamine release (Cardinal et al., 2002).

In unravelling the mechanisms of defence, it is equally important, besides the mechanisms of fear learning, to study the underlying processes of safety learning in extinction after Pavlovian fear conditioning. Extinction is a form of inhibitory conditioning and refers to a decrement in the conditioned 
response, specifically as a result of the repeated presentation of the CS in the absence of the US. It is an active form of inhibitory learning that competes with excitatory fear conditioning. Given the pivotal role of the amygdala in fear acquisition, it is not surprising that one considers it to be related to extinction as well. Research previously conducted on extinction of learned fear alludes on the interaction between the medial prefrontal cortex (mPFC) and the amygdala (Morgan et al., 1993; Quirk and Gehlert, 2003).

\section{I maging of defensive systems in humans: outline of the present thesis}

\section{Functional magnetic resonance imaging and diffusion tensor imaging in short}

Basic principles of magnetic resonance imaging (MRI)

Magnetic resonance neuroimaging offers a technique to visualize the functional and structural brain in a non-invasive way. There is no need for Xradiation or the administration of contrast media or radioactive tracers.

Images are derived from the magnetic resonance properties of nuclear particles. When atomic nuclei are immersed in a strong and homogenous magnetic field, the protons will align with this field until thermal equilibrium, and will rotate about the applied field at a characteristic frequency given by the Larmor equation, but with a random phase. Protons will absorb energy when a brief radio frequency (RF) electromagnetic pulse, oscillating at the Larmor frequency, is applied. This disturbs the equilibrium and introduces a transient phase coherence. When switching off the RF-field, the protons will 'relax' and emit energy which can be reconstructed into an image.

Given the fact that the rotation frequency depends on the applied external field strength, it is possible to separate signals from different locations according to their frequency by forming a spatially varying magnetic field.

\section{Functional MRI (fMRI)}

Active brain areas increase the metabolism of their neuronal and glial cell populations and hence will need an adequate supply of oxygen. After an initial slight drop in the blood oxygen level, indicating an increase in cerebral metabolic rate of oxygen, a huge increase in oxygen concentration will take place due to a blood flow overcompensating the oxygen demand (Malonek et al., 1997; Malonek and Grinvald, 1996). This leads to a local increase of blood oxygenation during brain activation. The magnetic state of iron contained in hemoglobin, the oxygen-carrying molecule of the blood, is dependent on the amount of oxygen bound. In other words, deoxygenated blood has different magnetic properties than oxygenated hemoglobin. 
With functional MRI, one visualizes these physiological changes in oxy- and deoxyhemoglobin concentration. It measures the so-called blood oxygenation level dependent (BOLD) response (Howseman and Bowtell, 1999). The most common fMRI data acquisition method to visualize the working brain is echo-planar imaging (EPI) which makes it possible to form complete MR images within seconds (Mansfield and Maudsley, 1977).

\section{Diffusion Tensor Imaging (DTI)}

While fMRI tells us more about the functional grey matter of the brain, diffusion tensor imaging can contribute to our structural view of white matter. DTI is an MRI-based technique that can map white matter anatomical connections in the living human brain non-invasively.

DTI measures the diffusion of water in different regions of the brain. Diffusion is a three-dimensional process, and hence molecular mobility in tissues may not be the same in all directions, hence called anisotropic. The water molecules bounce, cross, or interact with many tissue components such as cell membranes, fibers, or macromolecules. As such, a diffusion MRI image reflects the displacement distribution of the water molecules on a statistical basis, which varies with tissue environment, in each imaging voxel. Subsequent processing calculates a principal direction of diffusion. White matter, for example, has an anisotropic diffusion due to its specific organization in bundles running in parallel. The diffusion in the direction of the fibers is faster than perpendicular to them.

\section{Outline of the present thesis}

The present thesis focuses on the neural substrate of fear and panic in humans using magnetic resonance imaging (MRI) techniques (explained in short in the next paragraph).

Chapter two describes the neural correlates of human fear by using the clinical condition of spider phobia as a model. Confronting phobic subjects with pictures of their feared animal can be seen as an intermediate threat level. Functional MRI data from spider phobics and healthy control subjects is compared when viewing pictures of spiders, snakes and neutral objects.

Phobia is a pathological form of fear involving exaggerated responses to stimuli that are not intrinsically dangerous. This could mean that these stimuli acquired their significance through a process of learning. As seen in the former paragraph, unlearning of fear, or safety learning, can be accomplished by an extinction process. Psychological therapies, such as exposure therapy, are based on this process. In this light, chapter three investigates the functional changes in spider phobic subjects following one single session of cognitive-behavioural exposure therapy.

To gain further insight into the neural correlates of fear, it is equally important not only to study functional changes but also structural changes in 
the pathways connecting the different brain structures. For example, the link between the amygdala and the nucleus accumbens might also be important in explaining the neural underpinnings of the effects of psychological therapies for anxiety and fear disorders. The nucleus accumbens dopamine is believed to play a central role in motivational processes. For this reason, white matter changes following therapy are explored in chapter four.

It is known that the amygdala is important in the processing of emotional stimuli, and not solely fear. As mentioned above, this structure consists of several subgroups of nuclei. It is plausible that different nuclei subserve different functions in emotion processing. Chapter five aims at differentiating the role of amygdala subgroups using probability maps in a paradigm wellknown to induce amygdala activation.

The last chapter is an attempt to shed light on the highest level of threat, namely: panic. The availability of experimental procedures to study the phenomenon of human panic attacks in the laboratory has greatly improved our understanding of the underlying mechanisms of panic. The best validated procedures involve the administration of a chemical substance such as lactate or carbon dioxide (Esquivel et al., 2008). A possible common underlying mechanism concerns changes in brain pH that are brought about by both lactate and carbon dioxide. Intracellular $\mathrm{pH}$ needs to be regulated between very narrow margins to ensure survival. Slight disturbances of $\mathrm{pH}$ would consist in a vital threat, originating from within the body (Esquivel et al., 2009). In the model by Gray and McNaughton, this would primarily lead to activation of brain structures such as the dPAG and consequently also of the hypothalamus and amygdala. Cortical representation of these bodily internal signals would be expected at the level of the insula. This is investigated in chapter seven which presents pilot data of a functional MRI study with 7\% CO2-administration in panic disorder patients and healthy subjects. 


\section{References}

Blanchard DC, Blanchard RJ. 2008. Defensive behaviors, fear, and anxiety. In: Blanchard RJ, Blanchard DC, Griebel G, Nutt DJ, editors. Handbook of anxiety and fear. Amsterdam: Elsevier Academic Press.

Blanchard RJ, Blanchard DC. 1990. An ethoexperimental analysis of defense, fear and anxiety. In: McNaughton N, Andrews G, editors. Anxiety. Dunedin: Otago University Press. p 124133.

Bush G, Luu P, Posner MI. 2000. Cognitive and emotional influences in anterior cingulate cortex. Trends Cogn Sci 4(6):215-222.

Cain CK, LeDoux JE. 2008. Brain mechanisms of Pavlovian and instrumental aversive conditioning. In: Blanchard RJ, Blanchard DC, Griebel G, Nutt DJ, editors. Handbook of anxiety and fear. Amsterdam: Elsevier Academic Press.

Cardinal RN, Parkinson JA, Hall J, Everitt BJ. 2002. Emotion and motivation: the role of the amygdala, ventral striatum, and prefrontal cortex. Neurosci Biobehav Rev 26(3):321-52.

Craig AD. 2003. Interoception: the sense of the physiological condition of the body. Current Opinion in Neurobiology 13(4):500-505.

Craig AD. 2004. Human feelings: why are some more aware than others? Trends in Cognitive Sciences 8(6):239-241.

Davis M. 1992. The role of the amygdala in conditioned fear. In: Aggleton JP, editor. The Amygdala: Neurobiological aspects of emotion, memory, and mental dysfunction. New York: Wiley-Liss. p 255-305.

Davis M. 1997. Neurobiology of fear responses: the role of the amygdala. J Neuropsychiatry Clin Neurosci 9(3):382-402.

Esquivel G, Schruers K, Griez E. 2008. Experimental models: panic and fear. In: Blanchard RJ, Blanchard DC, Griebel G, Nutt DJ, editors. Handbook of anxiety and fear. Amsterdam: Elsevier Academic Press.

Esquivel G, Schruers K, Maddock RJ, Colasanti A, Griez E. 2009. Acids in the brain: A factor in panic? Journal of Psychopharmacology.

Graeff FG. 1994. Neuroanatomy and neurotransmitter regulation of defensive behaviors and related emotions in mammals. Braz J Med Biol Res 27(4):811-29.

Gray JA, McNaughton N. 2000. The Neuropsychology of Fear. Oxford: Oxford University Press.

Howseman AM, Bowtell RW. 1999. Functional magnetic resonance imaging: imaging techniques and contrast mechanisms. Philos Trans R Soc Lond B Biol Sci 354(1387):1179-94.

LeDoux J. 2007. The amygdala. Current Biology 17(20):R868-R874.

LeDoux JE. 1994. Emotion, memory and the brain. Sci Am 270(6):50-7.

LeDoux JE. 2000. Emotion circuits in the brain. Annu Rev Neurosci 23:155-84.

Malonek D, Dirnagl U, Lindauer U, Yamada K, Kanno I, Grinvald A. 1997. Vascular imprints of neuronal activity: relationships between the dynamics of cortical blood flow, oxygenation, and volume changes following sensory stimulation. Proc Natl Acad Sci U S A 94(26):14826-31.

Malonek D, Grinvald A. 1996. Interactions between electrical activity and cortical microcirculation revealed by imaging spectroscopy: implications for functional brain mapping. Science 272(5261):551-4.

Mansfield P, Maudsley AA. 1977. Medical imaging by NMR. Br J Radiol 50(591):188-94.

McNaughton N, Corr PJ. 2004. A two-dimensional neuropsychology of defense: fear/anxiety and defensive distance. Neurosci Biobehav Rev 28(3):285-305.

McNaughton N, Gray JA. 2000. Anxiolytic action on the behavioural inhibition system implies multiple types of arousal contribute to anxiety. J Affect Disord 61(3):161-76.

McNaughton N, Zangrossi $\mathrm{HJ}$. 2008. Theoretical approaches to the modeling of anxiety in animals. In: Blanchard RJ, Blanchard DC, Griebel G, Nutt DJ, editors. Handbook of anxiety and fear. Amsterdam: Elsevier Academic Press.

Morgan MA, Romanski LM, LeDoux JE. 1993. Extinction of emotional learning: contribution of medial prefrontal cortex. Neurosci Lett 163(1):109-13. 
Pezze MA, Feldon J. 2004. Mesolimbic dopaminergic pathways in fear conditioning. Prog Neurobiol 74(5):301-20.

Quirk GJ, Gehlert DR. 2003. Inhibition of the amygdala: key to pathological states? Ann N Y Acad Sci 985:263-72. 



\section{CHAPTER I I}

\section{Visual Presentation of Phobic Stimuli: Amygdala Activation via an Extrageniculostriate Pathway?}

L. Goossens, K. Schruers, R. Peeters, E. Griez, S. Sunaert

Psychiatry Research: Neuroimaging 155 (2007) 113-120 


\section{Abstract}

In the present study, event-related functional magnetic resonance imaging (fMRI) was used to examine the neural correlates of phobic fear by exposing spider phobic subjects to a visual presentation of spiders. In contrast to control subjects, spider phobics showed significant increased activation in the amygdala and the pulvinar nucleus of the thalamus on the basis of region of interest (ROI) analysis. Furthermore, voxelwise analysis revealed increased activation related to phobia-specific pictures bilaterally in the anterior cingulate cortex, the left insular cortex and bilaterally in the supplementary motor area. These findings confirm the involvement of the amygdala in the processing of phobia-relevant stimuli as found earlier in a recent study. Moreover, the thalamus findings support the involvement of an extrageniculostriate pathway in the process of phobic fear. 


\section{Introduction}

Fear can be seen as an automatic response to danger that is essential for survival, a natural reaction seen in everyday life. When this reaction becomes more pronounced than acceptable in a given situation, or when it arises in an inappropriate situation, it becomes a fear or anxiety disorder (Marks, 1987; Öhman, 1992).

The amygdala is very often referred to in studies on fear (Davis and Whalen, 2001; Zald, 2003). Activation of the amygdala occurs in healthy individuals processing faces expressing fear compared to neutral faces, as well as other potentially threatening material. Fear conditioning studies also point to the importance of the amygdala in the acquisition of fear. Furthermore, previous studies with social phobic patients (Birbaumer et al., 1998) and individuals suffering from posttraumatic stress disorder (PTSD) (Gilboa et al., 2004) implicate the amygdala in symptom provocation paradigms.

Activation of the amygdala has been said to be mediated by a subcortical pathway passing through the pulvinar nucleus of the thalamus (LeDoux, 1996). This route bypasses the primary sensory cortices. Inputs from the thalamus to the amygdala would facilitate transmission of rough, but rapid, signals about fear-related stimuli, thus enabling one to respond reflexively and rapidly to danger. Evidence in favour of such a pathway comes from behavioural and functional studies of patients with selective brain lesions (Morris et al., 2001a; Ward et al., 2005). For example, 'blindsight' patients with striate lesions who are unable to consciously perceive visual stimuli, still show activity in the pulvinar region in response to fear-related stimuli (Morris et al., 2001b).

Despite the widely accepted central role of the amygdala in the cascade of fear processing, people suffering from specific phobia, known to typically display exaggerated fear towards a specific stimulus or even a picture of that stimulus (Cuthbert et al., 2003), fail to show amygdala activation in most of the imaging studies conducted up to date (Fredrikson et al., 1993; Johanson et al., 1998; Rauch et al., 1995). In 2003, Dilger et al. were the first to provide evidence of the involvement of the amygdala in phobic fear. By means of event-related functional magnetic resonance imaging (fMRI), they demonstrated increased amygdala activation in phobic subjects confronted with a picture of their feared object. It has been suggested that the negative outcomes from previous studies were due to the presentation of stimuli in blocks of a certain amount of time. This sustained presentation may have caused habituation of the rapid amygdala responses (see (Breiter et al., 1996; Buchel et al., 1998).

The present study seeks to replicate and provide further evidence for the involvement of the amygdala in phobic fear. Moreover, since the reaction of 
phobics to their feared stimulus has also been described as reflexive (LeDoux, 1996), it is conceivable that in such an automatic fear-reaction the amygdala will be rapidly activated via the subcortical pathway, in parallel to classic route via the primary visual cortex. If this is true, we hypothesize that there will also be increased thalamic activation during phobia-relevant picture processing.

\section{Methods}

\section{Subjects}

Participants were 13 female and 2 male subjects with spider phobia (mean age $=24$ years, $\mathrm{SD}=2$ ) and 12 female and 2 male control subjects (mean age $=23$ years, $S D=1$ ), all recruited by public advertisement. Subjects received a small financial compensation $(€ 15)$ for their participation.

Subjects were diagnosed as spider phobics prior to the experiment using a structured psychiatric interview [Mini International Neuropsychiatric Interview, MINI, (Sheehan et al., 1998)]. In addition, we used the selfadministered Spider Phobia Questionnaire [SPQ (Klorman et al., 1974)] (mean $=21, S D=2$ ). All spider phobic subjects were untreated. Control subjects did not reveal any signs of phobia $(S P Q$ mean $=2, S D=1)$. All subjects were free of additional psychopathology according to the MINI, including specific phobia for snakes. Right-handedness was assessed with the Edinburgh Handedness Inventory (Oldfield, 1971). Written informed consent was obtained from each participant prior to the experiment. The study was approved by the local ethics committee.

\section{Design}

We adopted a paradigm previously described by Dilger et al. (2003).

Subjects were exposed to a series of spider (phobia-relevant), snake (potentially fear-relevant), and neutral stimuli taken from the International Affective Picture System, and a fixation cross as a null event (27 pictures from each category). The snakes were introduced to control for possible hyperreactivity to threat-related stimuli in general. All stimuli were equated for visual content.

Pictures were presented in a random order for $1 \mathrm{~s}$ each with a variable interstimulus interval of $2.25 \mathrm{~s}$ to $9 \mathrm{~s}$ between succeeding stimuli. The pictures were viewed by means of a mirror attached to the head coil, and the instruction was given to look attentively at the stimuli.

\section{I maging}

Brain images were acquired using a 3.0 Tesla Philips Intera scanner. Structural image acquisition consisted of a $\mathrm{T}_{1}$-weighted 3D Turbo Field Echo 
(TFE) scan, with a resolution of $1 \mathrm{~mm}$ isotropically. For functional images a total of 450 (225 per time series) images were acquired for every subject using a $\mathrm{T}_{2}{ }^{*}$-weighted gradient echo echo planar imaging sequence (GE-EPI) with 28 axial slices (slice thickness $=4.5 \mathrm{~mm}$, gap $=0.5 \mathrm{~mm}$ ) covering the whole brain ( $T R=2 \mathrm{~s}, \mathrm{TE}=30 \mathrm{~ms}$, FOV $=230 \times 230$, matrix $=80 \times 80$, SENSitivity Encoding (SENSE) reduction factor $=2.5$ ).

For the preprocessing and statistical analyses, the statistical parametric mapping software package (SPM2, Wellcome Departement of Cognitive Neurology, London) implemented in Matlab (Mathworks, Natick, Mass., USA, release 13) was used.

The functional images were realigned to the first volume of the time series to correct for head movements, and slice timing was applied to correct for differences in acquisition time during scanning. After co-registering the functional images to the anatomical image, they were spatially normalized to the standard space of the Montreal Neurological Institute brain (MNI-brain). All functional images were subsampled to a voxel size of $2 \times 2 \times 2 \mathrm{~mm}$ and smoothed with a Gaussian kernel of $10 \mathrm{~mm}$ full width at half maximum (FWHM).

First-level statistical analysis was done for all subjects in the context of the General Linear Model. Each of the experimental conditions (spider, snake, neutral, and fixation) was modelled by a boxcar function convolved with a hemodynamic response function with its time derivatives and their parametric modulation over time in the general linear model (GLM). We calculated the t-contrasts "Spider $>$ Neutral", "Snake>Neutral", and "Spider>Snake" for each subject. The individual contrast images were used in a second-level random effects analysis, which accounts for both scan-toscan and subject-to-subject variability, to determine stimuli-specific regional responses for within- and between-group statistical comparisons (one-way ANOVA). The results of the voxelwise analysis are reported at $P<0.05$, corrected for multiple comparisons using the False Discovery Rate (FDR) (Genovese et al., 2002).

Because of a priori hypothesis regarding the response in the amygdala and thalamus, a region of interest (ROI) analysis was conducted in these brain areas. The ROIs have been defined by the anatomical parcellation of the normalized brain (single subject high-resolution T1 volume of the Montreal Neurological Institute) as described by (Tzourio-Mazoyer et al., 2002). The significance level was set at $P<0.05$, and corrected for the specific volume of interest.

\section{Results}

The ROI analysis (table I) for the contrast 'spider versus neutral' pictures between phobics and controls showed significant more increase in activation 
in our phobics in the left amygdala (figure $1 \mathrm{~A}$ ). As hypothesized, there was also a significant increase in thalamus activity, bilateral, for our spider phobic subjects looking at spider pictures compared to neutral ones (figure $1 B$ ). The voxelwise analysis (table I, figure 2) further confirmed the activation in the right thalamus. In addition, this analysis revealed significant increase bilaterally in the anterior cingulate cortex (ACC) and the left insula, bilateral in the supplementary motor area (SMA, superior frontal gyrus), the fusiform and the lingual gyrus. As well as in the voxelwise analysis as in the ROI analysis, there was no significant more increase in activation in the control subjects than in the spider phobic subjects for this contrast.

Table I. Significant activation to Spider vs. Neutral pictures for Phobics $>$ Controls

\begin{tabular}{|c|c|c|c|c|c|c|}
\hline \multicolumn{7}{|l|}{ Spiders > Neutral } \\
\hline \multirow[t]{2}{*}{ Brain area } & \multirow[t]{2}{*}{$\mathbf{L} / \mathbf{R}$} & \multirow[t]{2}{*}{$\boldsymbol{P}_{\mathrm{FDR}}$} & \multirow[t]{2}{*}{ t-value } & \multicolumn{3}{|c|}{ Talairach Coordinates } \\
\hline & & & & $\mathbf{x}$ & $\mathbf{y}$ & $\mathbf{z}$ \\
\hline \multicolumn{7}{|l|}{ Voxe/wise } \\
\hline Thalamus,Pulvinar & $\mathrm{R}$ & 0.000 & 7.91 & 2 & -29 & 1 \\
\hline Thalamus,medial dorsal nucleus & L & 0.000 & 5.51 & -4 & -15 & 10 \\
\hline Thalamus, ventral anterior nucleus & $\mathrm{R}$ & 0.002 & 4.69 & 14 & -1 & 11 \\
\hline Posterior Cingulate cortex & $\mathrm{L}$ & 0.006 & 4.01 & -2 & -40 & 20 \\
\hline Anterior cingulate gyrus & $\mathrm{R}$ & 0.000 & 6.66 & 6 & 23 & 25 \\
\hline Anterior cingulate gyrus & $\mathrm{L}$ & 0.000 & 5.86 & -4 & 26 & 24 \\
\hline Superior frontal gyrus (SMA) & $\mathrm{L}$ & 0.001 & 4.95 & -6 & 0 & 70 \\
\hline Superior frontal gyrus (SMA) & $\mathrm{R}$ & 0.002 & 4.48 & 12 & 9 & 66 \\
\hline Fusiform gyrus & $\mathrm{R}$ & 0.000 & 6.38 & 40 & -67 & -15 \\
\hline Lingual gyrus & $\mathrm{R}$ & 0.001 & 5.30 & 2 & -86 & -11 \\
\hline Fusiform gyrus & $\mathrm{L}$ & 0.001 & 5.02 & -18 & -77 & -16 \\
\hline Lingual gyrus & $\mathrm{L}$ & 0.001 & 4.96 & -16 & -90 & -14 \\
\hline Superior temporal gyrus & $\mathrm{R}$ & 0.001 & 5.02 & 59 & 13 & -7 \\
\hline Insula & L & 0.005 & 4.04 & -40 & 13 & -4 \\
\hline Parahippocampal gyrus & $L$ & 0.008 & 3.86 & -18 & 1 & -12 \\
\hline Precuneus & $\mathrm{L}$ & 0.031 & 3.18 & -6 & -57 & 64 \\
\hline \multicolumn{7}{|l|}{ ROI } \\
\hline Amygdala & L & 0.013 & 3.71 & -18 & -1 & -14 \\
\hline Thalamus, pulvinar & $\mathrm{R}$ & 0.000 & 7.18 & 6 & -29 & 3 \\
\hline Thalamus, pulvinar & L & 0.004 & 3.53 & -6 & -29 & 5 \\
\hline
\end{tabular}

SMA, supplementary motor cortex; $L$, left; $R$, right; Talairach coordinates of maximally activated voxel [Activation threshold: $P_{\mathrm{FDR}}$ corrected $<0$ ] 
The ROI analysis (table II) for the contrast 'spider minus snake' confirmed the involvement of the right thalamus. The voxelwise analysis (table II) revealed more activation bilaterally in the anterior cingulate and the left insula. Furthermore, the SMA, the fusiform and the lingual gyrus were bilaterally more active in phobic subjects than in control subjects when looking at spiders compared to snakes. Yet again, there was no significant more increase in activation in the control subjects than in the spider phobic subjects for this contrast.

Controls and phobics showed similar responses looking at snakes compared to neutral pictures.

Table II. Significant activation to Spider vs. Snake pictures for Phobics $>$ Controls

\begin{tabular}{|c|c|c|c|c|c|c|}
\hline \multicolumn{7}{|l|}{ Spiders > Snakes } \\
\hline \multirow[t]{2}{*}{ Brain area } & \multirow[t]{2}{*}{ L/ R } & \multirow[t]{2}{*}{$\boldsymbol{P}_{\mathrm{FDR}}$} & \multirow[t]{2}{*}{ t-value } & \multicolumn{3}{|c|}{ Talairach Coordinates } \\
\hline & & & & $\mathbf{x}$ & $\mathbf{y}$ & $\mathbf{z}$ \\
\hline \multicolumn{7}{|l|}{ Voxelwise } \\
\hline Fusiform gyrus & $\mathrm{R}$ & 0.001 & 6.54 & 24 & -82 & -11 \\
\hline Lingual gyrus & $\mathrm{R}$ & 0.003 & 5.11 & 20 & -95 & -5 \\
\hline Posterior cerebellum, declive & $\mathrm{R}$ & 0.003 & 5.09 & 32 & -67 & -12 \\
\hline Inferior occipital gyrus & $\mathrm{R}$ & 0.003 & 5.08 & 12 & -90 & -9 \\
\hline Posterior cerebellum, declive & L & 0.004 & 4.84 & -42 & -59 & -22 \\
\hline Anterior cerebellum, Culmen & $\mathrm{L}$ & 0.005 & 4.58 & -40 & -50 & -26 \\
\hline Fusiform gyrus & $\mathrm{L}$ & 0.006 & 4.38 & -24 & -90 & -12 \\
\hline Lingual gyrus & L & 0.007 & 4.29 & -2 & -70 & 0 \\
\hline Anterior Cingulate gyrus & $\mathrm{R}$ & 0.002 & 6.16 & 2 & 15 & 36 \\
\hline Anterior Cingulate gyrus & $\mathrm{L}$ & 0.002 & 5.77 & -4 & 23 & 28 \\
\hline Superior frontal gyrus (SMA) & $\mathrm{R}$ & 0.006 & 4.38 & 6 & 19 & 62 \\
\hline Superior frontal gyrus (SMA) & $\mathrm{L}$ & 0.018 & 3.74 & 0 & 6 & 49 \\
\hline Superior temporal gyrus & $\mathrm{R}$ & 0.003 & 5.03 & 61 & 10 & -2 \\
\hline Insula & L & 0.004 & 4.79 & -51 & 13 & -6 \\
\hline Superior frontal gyrus & $\mathrm{L}$ & 0.016 & 3.82 & -32 & 52 & 25 \\
\hline Cuneus & $\mathrm{R}$ & 0.024 & 3.57 & 20 & -68 & 9 \\
\hline Posterior cingulate gyrus & $\mathrm{L}$ & 0.026 & 3.54 & -2 & -32 & 24 \\
\hline Anterior cerebellum, Culmen & $\mathrm{R}$ & 0.029 & 3.46 & 32 & -46 & -23 \\
\hline Thalamus, medial dorsal nucleus & $\mathrm{R}$ & 0.036 & 3.34 & 4 & -15 & 10 \\
\hline \multicolumn{7}{|l|}{$\underline{R O I}$} \\
\hline Thalamus, Pulvinar & $\mathrm{R}$ & 0.023 & 3.29 & 6 & -29 & 3 \\
\hline
\end{tabular}

SMA, supplementary motor cortex; L, left; $R$, right; Talairach coordinates of maximally activated voxel [Activation threshold: $P_{\text {FDRcorrected }}<0$ ] 


\section{Discussion}

The present study explored the pathways of fear by exposing spider phobics to pictures of their feared animal in comparison with a healthy control group.

Consistent with Dilger et al. (2003), the involvement of the amygdala was replicated. Additionally, our findings implicate the pulvinar nucleus of the thalamus in the process of phobic fear. Furthermore, voxelwise analysis revealed increased activity in the ACC, the left insular cortex, and bilateral in the SMA.

\section{Amygdala}

The results of the current study replicate and confirm the amygdala activation in phobic fear as found by Dilger et al. (2003). The amygdala activity observed in the present study is identical to the amygdala cluster found by the latter authors. In contrast, a PET study on spider phobia (Veltman et al., 2004) found increased activation in the right amygdalar region in response to spider pictures in their phobic group compared to the control group. On the other hand, while studying contamination fear in patients with obsessive compulsive disorder, the same group (van den Heuvel et al., 2004) demonstrated enhanced activity in the left amygdala in response to contamination stimuli compared to neutral pictures. The found amygdala cluster is also similar to the one found in this study. Furthermore some studies associate the amygdala with social phobia (Birbaumer et al., 1998; Lorberbaum et al., 2004; Tillfors et al., 2002), although the implication of this structure in social phobia is not always found (Van Ameringen et al., 2004). These mixed results concerning the amygdala in fear and anxiety research may be due to methodological differences, for instance: imaging modality (PET vs fMRI), timing issues (sustained vs rapid presentation) or analysis methods (voxelwise vs ROI, differences in thresholding). However, the present left-sided amygdala activation is consistent with the majority of neuroimaging studies on emotion in general (Baas et al., 2004; Wager et al., 2003). A possible explanation for the lateralized amygdala activation, is the rate at which the left and right amygdala habituate. As found by (Wright et al., 2001), the right amygdala habituates faster than the left. Studies investigating the habituation of the amygdala (Morris et al., 1996; Phillips et al., 2001; Whalen et al., 1998), together with lesion studies (Glascher and Adolphs, 2003), raise the hypothesis that the right amygdala may be involved in rapid, and relatively undifferentiated, emotional stimulus detection, which may be needed for all visual stimuli. In contrast, the left amygdala may be associated with sustained stimulus evaluation that discriminates differences in arousal magnitude. Thus, by making a contrast 'spider more than neutral', it is possible to yield only the left amygdala, assuming that the spider pictures 
need more evaluation than a neutral stimulus due to their arousing nature for a phobic individual.

It is noteworthy to mention that we were not able to demonstrate a significantly different level of amygdala activation between control and phobic subjects for the contrast 'spider-snake'. This is probably due to the selection criteria which allowed for a certain variation in the degree of fear for snakes. In the case of snakes, only the categorical question "phobia or not" was assessed, while the fear for spiders was assessed in a categorical as well as in a dimensional way (SPQ). This might have led to a slight activation of the amygdala in response to snake pictures in some of our subjects, introducing a high variability in the direct comparison between spiders versus snakes. This may explain the amygdala activation being just below the threshold.

It is also worth mentioning that a link between amygdala activity and negative affect in general is a prevalent view in the literature (LeDoux, 2000). Recent evidence from human studies, along with other studies in animals, is even converging on a broader view of the amygdala's role in directing attention to affectively salient stimuli that have major significance for the individual (Davidson, 2003).

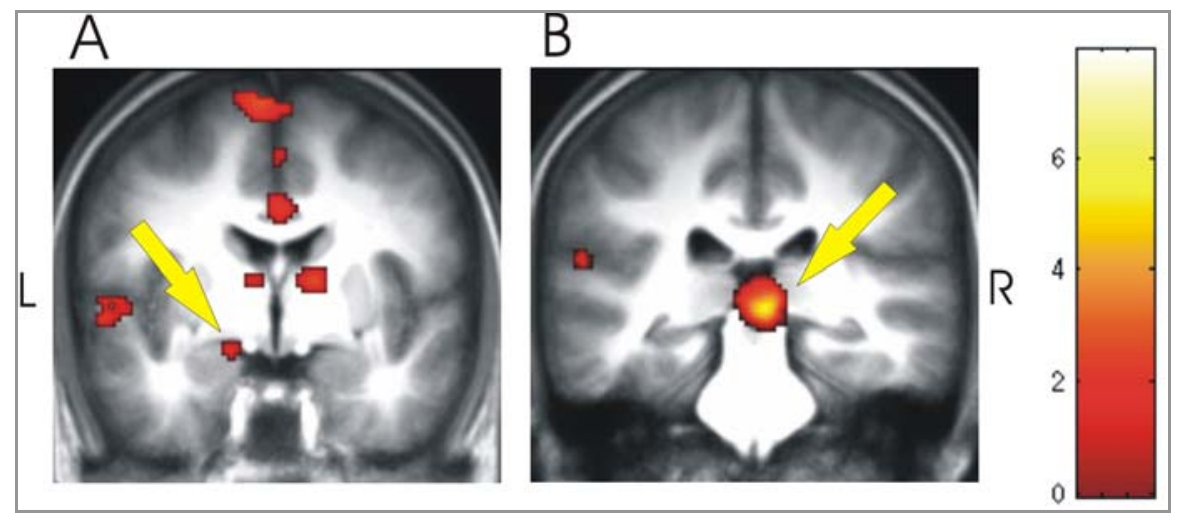

Fig.1: Activation maps showing significant $(P F D R<0.05)$ more BOLD signal in the phobics compared to the controls in the (A) left amygdala and the (B) pulvinar nucleus of the thalamus for the contrast 'Spider $>$ Neutral'

\section{Pulvinar}

The second aim of our study was to find increased thalamic activation during phobia-relevant picture processing. The thalamic pulvinar activation we found is indeed in agreement with the subcortical pathway encompassing the superior colliculus and the thalamic pulvinar proposed by LeDoux (1996). 
As mentioned in the introduction, this route enables both humans and animals to respond to danger rapidly and reflexively.

It should be noted that we used visual fear evoking stimuli. Evidence suggest that the majority of the pulvinar nucleus is involved in vision (Robinson and Petersen, 1992). The most widely accepted theory is that the pulvinar is implicated in visual 'salience' or 'attention' (Grieve et al., 2000). This view is compatible with the proposal of pulvinar involvement in the subcortical visual pathway by which simple, fear-relevant signals are able to reach the amygdala. It is not surprising that a picture of a spider is a highly salient stimulus for phobic subjects, one that demands their full attention. Hence, the spider picture will need rapid processing.

\section{Anterior Cingulate Cortex}

The greater activation within the ACC to spider pictures in phobics than in control subjects may be related to the modulation of emotional responses. The ACC is the region where attentional and emotional functions are integrated (Damasio, 1994; Yamasaki et al., 2002). Earlier evidence highlighted the role of the ACC in autonomic control. Projections from the ACC to brainstem sites arise throughout the ventral and dorsal extent (An et al., 1998; Ongur et al., 1998; Vilensky and van Hoesen, 1981). Critchley (Critchley et al., 2005) suggests that the ACC provides an interface between low-level visceral systems that may influence behavioural adaptation. Damage to this structure in humans is associated with a reduction in spontaneous, compulsive, and emotional motor responses (Cohen et al., 1999). Thus, the ACC seems important in the selection of the appropriate response. Furthermore, ACC activation is increased when healthy subjects process a negative facial expression and evaluate emotional response (Blair et al., 1999; Phan et al., 2003). ACC activation is also seen in other studies on specific phobia (Rauch et al., 1995).

\section{I nsula}

Usually in concert with the ACC, the insular cortex is activated during states of autonomic arousal (Aziz et al., 2000; Buchel et al., 1998; Cameron and Minoshima, 2002; Craig et al., 2000; Critchley et al., 2000; Critchley et al., 2001; Critchley et al., 2003; Critchley et al., 2002; Harper et al., 2000; Peyron et al., 2002). As such, activation is induced by visceral stimulation (Aziz et al., 2000), pain (Peyron et al., 2002), temperature (Craig et al., 2000), emotional processing (Buchel et al., 1998; Phillips et al., 1998), and a variety of aversive stimuli (Phillips et al., 1997; Schienle et al., 2002; Williams et al., 2005). Activation in the anterior insula has also been reported in other simple phobia studies (Dilger et al., 2003; Rauch et al., 1995; Reiman, 1997). 
This part of the cortex seems to be implicated in the representation of internal bodily states. The insular cortex is positioned to exert control over visceral and autonomic functions via its connections to the brain stem, diencephalons, and amygdala (Mesulam, 1985; Mufson et al., 1981). Moreover, it has a unique position in mediating between sensory input, the autonomic/visceral systems, and other regions of the brain involved in higher order processing (Wright et al., 2003).

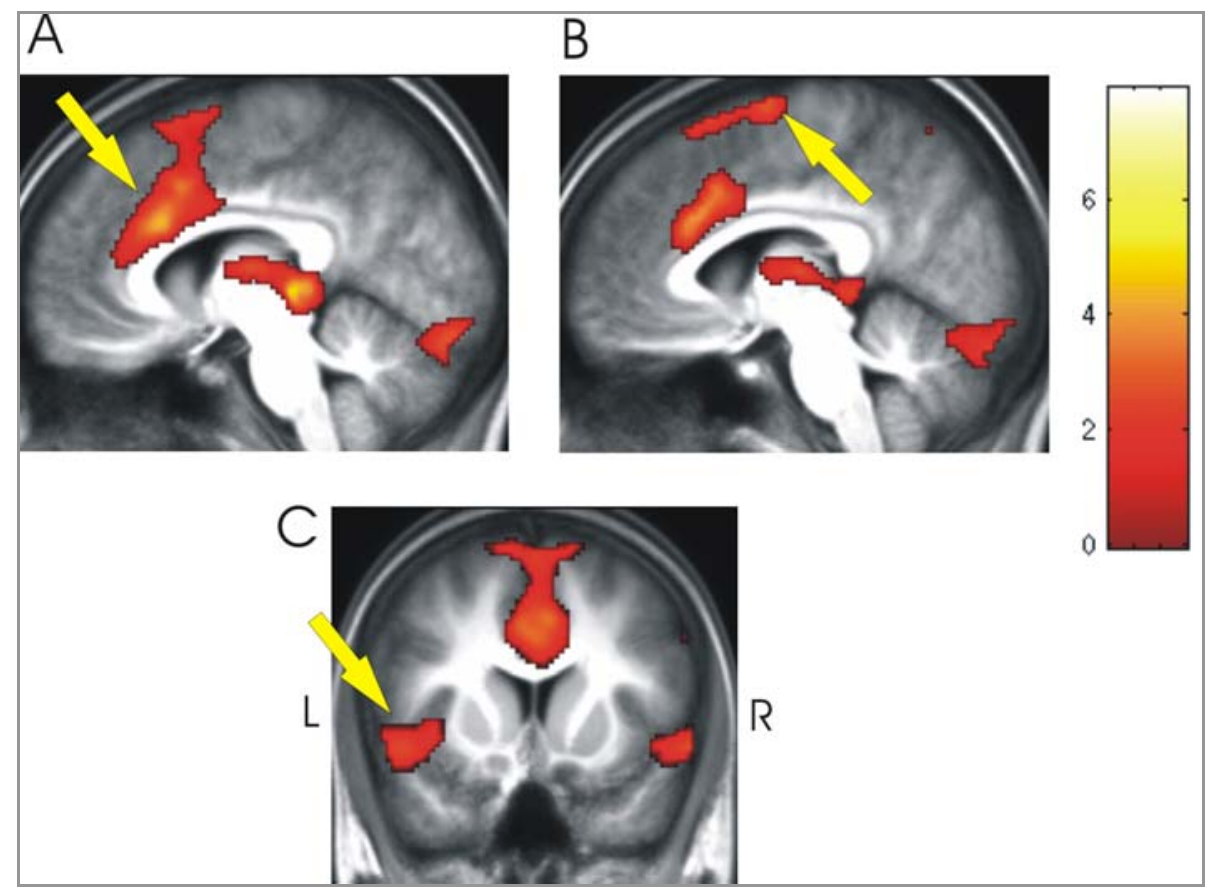

Fig. 2: Activation maps showing significant $\left(P_{\mathrm{FDR}}<0.05\right)$ more BOLD signal in the phobics compared to the controls in the $(A)$ anterior cingulate cortex, the (B) supplementary motor cortex, and the $(\mathrm{C})$ insula for the contrast 'Spider>Neutral'. (color bar indicating t-value)

\section{Supplementary motor area}

The supplementary motor area (SMA) was more active in spider phobic subjects than in controls when they were confronted with the object of their phobia. Such activation may be related to the urge to flee. Similar effects have been reported in social phobics during a public speaking task (Reiman, 1997) and in fear conditioning studies by (Buchel et al., 1998) and LaBar et al. (LaBar et al., 1998). 


\section{Limitation and Conclusion}

The main limitation of this study is that we did not include on-line measurements of emotional response such as rating scales or psychophysiological assessment. However, there is little doubt that our phobic subjects had a true phobic reaction. Severe selection criteria were used to recruit our phobic subjects. All of them were carefully diagnosed by an experienced psychiatrist using strict DSM-IV criteria. Mean SPQ-score was 21 for our spider phobic subjects contrasting with a mean score of 2 for the healthy controls. As a matter of fact, retrospective evaluation immediately after the scanning procedure revealed that all our phobic subjects had felt "uncomfortable" during the presentation of spider pictures.

To conclude, using an event-related paradigm, we replicated the result of Dilger et al. (2003), confirming the involvement of the amygdala in phobic fear.

The findings of the present study also implicate the pulvinar nucleus of the thalamus. This nucleus is part of the subcortical 'quick and dirty route' which was earlier proposed by LeDoux (1996). 


\section{References}

An X, Bandler R, Ongur D, Price JL. 1998. Prefrontal cortical projections to longitudinal columns in the midbrain periaqueductal gray in macaque monkeys. J Comp Neurol 401(4):455-79.

Aziz Q, Schnitzler A, Enck P. 2000. Functional neuroimaging of visceral sensation. J Clin Neurophysiol 17(6):604-12.

Baas D, Aleman A, Kahn RS. 2004. Lateralization of amygdala activation: a systematic review of functional neuroimaging studies. Brain Res Brain Res Rev 45(2):96-103.

Birbaumer N, Grodd W, Diedrich O, Klose U, Erb M, Lotze M, Schneider F, Weiss U, Flor H. 1998. fMRI reveals amygdala activation to human faces in social phobics. Neuroreport 9(6):1223-6.

Blair RJ, Morris JS, Frith CD, Perrett DI, Dolan RJ. 1999. Dissociable neural responses to facial expressions of sadness and anger. Brain 122 ( Pt 5):883-93.

Breiter HC, Etcoff NL, Whalen PJ, Kennedy WA, Rauch SL, Buckner RL, Strauss MM, Hyman SE, Rosen BR. 1996. Response and habituation of the human amygdala during visual processing of facial expression. Neuron 17(5):875-87.

Buchel C, Morris J, Dolan RJ, Friston KJ. 1998. Brain systems mediating aversive conditioning: an event-related fMRI study. Neuron 20(5):947-57.

Cameron OG, Minoshima S. 2002. Regional brain activation due to pharmacologically induced adrenergic interoceptive stimulation in humans. Psychosom Med 64(6):851-61.

Cohen RA, Kaplan RF, Zuffante P, Moser DJ, Jenkins MA, Salloway S, Wilkinson H. 1999. Alteration of intention and self-initiated action associated with bilateral anterior cingulotomy. J Neuropsychiatry Clin Neurosci 11(4):444-53.

Craig AD, Chen K, Bandy D, Reiman EM. 2000. Thermosensory activation of insular cortex. Nat Neurosci 3(2):184-90.

Critchley HD, Corfield DR, Chandler MP, Mathias CJ, Dolan RJ. 2000. Cerebral correlates of autonomic cardiovascular arousal: a functional neuroimaging investigation in humans. J Physiol 523 Pt 1:259-70.

Critchley HD, Mathias CJ, Dolan RJ. 2001. Neural activity in the human brain relating to uncertainty and arousal during anticipation. Neuron 29(2):537-45.

Critchley HD, Mathias CJ, Josephs O, O'Doherty J, Zanini S, Dewar BK, Cipolotti L, Shallice T, Dolan RJ. 2003. Human cingulate cortex and autonomic control: converging neuroimaging and clinical evidence. Brain 126(Pt 10):2139-52.

Critchley HD, Melmed RN, Featherstone E, Mathias CJ, Dolan RJ. 2002. Volitional control of autonomic arousal: a functional magnetic resonance study. Neuroimage 16(4):909-19.

Critchley HD, Tang J, Glaser D, Butterworth B, Dolan RJ. 2005. Anterior cingulate activity during error and autonomic response. Neuroimage.

Cuthbert BN, Lang PJ, Strauss C, Drobes D, Patrick CJ, Bradley MM. 2003. The psychophysiology of anxiety disorder: fear memory imagery. Psychophysiology 40(3):40722.

Damasio AR. 1994. Descartes' error: emotion, reason and the human brain. New York: Grosset/Putnam.

Davidson RJ. 2003. Darwin and the neural bases of emotion and affective style. Ann N Y Acad Sci 1000:316-36.

Davis M, Whalen PJ. 2001. The amygdala: vigilance and emotion. Mol Psychiatry 6(1):13-34.

Dilger S, Straube T, Mentzel HJ, Fitzek C, Reichenbach JR, Hecht H, Krieschel S, Gutberlet I, Miltner WH. 2003. Brain activation to phobia-related pictures in spider phobic humans: an event-related functional magnetic resonance imaging study. Neurosci Lett 348(1):29-32.

Fredrikson M, Wik G, Greitz T, Eriksson L, Stone-Elander S, Ericson K, Sedvall G. 1993. Regional cerebral blood flow during experimental phobic fear. Psychophysiology 30(1):126-30.

Genovese CR, Lazar NA, Nichols T. 2002. Thresholding of statistical maps in functional neuroimaging using the false discovery rate. Neuroimage 15(4):870-8.

Gilboa A, Shalev AY, Laor L, Lester H, Louzoun Y, Chisin R, Bonne O. 2004. Functional connectivity of the prefrontal cortex and the amygdala in posttraumatic stress disorder. Biol Psychiatry 55(3):263-72. 
Glascher J, Adolphs R. 2003. Processing of the arousal of subliminal and supraliminal emotional stimuli by the human amygdala. J Neurosci 23(32):10274-82.

Grieve KL, Acuna C, Cudeiro J. 2000. The primate pulvinar nuclei: vision and action. Trends Neurosci 23(1):35-9.

Harper RM, Bandler R, Spriggs D, Alger JR. 2000. Lateralized and widespread brain activation during transient blood pressure elevation revealed by magnetic resonance imaging. J Comp Neurol 417(2):195-204.

Johanson A, Gustafson L, Passant U, Risberg J, Smith G, Warkentin S, Tucker D. 1998. Brain function in spider phobia. Psychiatry Res 84(2-3):101-11.

Klorman R, Weerts TC, Hastings JE, Melamed BG, Lang PJ. 1974. Psychometric description of some specific-fear questionnaires. Behavior therapy 5:401-409.

LaBar KS, Gatenby JC, Gore JC, LeDoux JE, Phelps EA. 1998. Human amygdala activation during conditioned fear acquisition and extinction: a mixed-trial fMRI study. Neuron 20(5):937-45.

LeDoux JE. 1996. The Emotional Brain. New York: Simon and Schuster.

LeDoux JE. 2000. Emotion circuits in the brain. Annu Rev Neurosci 23:155-84.

Lorberbaum JP, Kose S, Johnson MR, Arana GW, Sullivan LK, Hamner MB, Ballenger JC, Lydiard RB, Brodrick PS, Bohning DE and others. 2004. Neural correlates of speech anticipatory anxiety in generalized social phobia. Neuroreport 15(18):2701-5.

Marks I. 1987. Fears, Phobias, and Rituals: Panic, Anxiety and their disorders. New York: Oxford University Press.

Mesulam MM. 1985. The insula of Reil in man and monkey. In: Jones EG, Peters AA, editors. Cerebral Cortex. New York: Plenum Press.

Morris JS, Buchel C, Dolan RJ. 2001a. Parallel neural responses in amygdala subregions and sensory cortex during implicit fear conditioning. Neuroimage 13(6 Pt 1):1044-52.

Morris JS, DeGelder B, Weiskrantz L, Dolan RJ. 2001b. Differential extrageniculostriate and amygdala responses to presentation of emotional faces in a cortically blind field. Brain 124(Pt 6):1241-52.

Morris JS, Frith CD, Perrett DI, Rowland D, Young AW, Calder AJ, Dolan RJ. 1996. A differential neural response in the human amygdala to fearful and happy facial expressions. Nature 383(6603):812-5.

Mufson EJ, Mesulam MM, Pandya DN. 1981. Insular interconnections with the amygdala in the rhesus monkey. Neuroscience 6(7):1231-48.

Öhman A. 1992. Fear and anxiety as emotional phenomena: Clinical, phenomenological, evolutionary perspectives, and information-processing mechanisms. In: Lewis M, Haviland JM, editors. Handbook of the Emotions. New York: Guilford. p 511-536.

Oldfield RC. 1971. The assessment and analysis of handedness: the Edinburgh inventory. Neuropsychologia 9:97-113.

Ongur D, An X, Price JL. 1998. Prefrontal cortical projections to the hypothalamus in macaque monkeys. J Comp Neurol 401(4):480-505.

Peyron R, Frot M, Schneider F, Garcia-Larrea L, Mertens P, Barral FG, Sindou M, Laurent B, Mauguiere F. 2002. Role of operculoinsular cortices in human pain processing: converging evidence from PET, fMRI, dipole modeling, and intracerebral recordings of evoked potentials. Neuroimage 17(3):1336-46.

Phan KL, Liberzon I, Welsh RC, Britton JC, Taylor SF. 2003. Habituation of rostral anterior cingulate cortex to repeated emotionally salient pictures. Neuropsychopharmacology 28(7):1344-50.

Phillips ML, Medford N, Young AW, Williams L, Williams SC, Bullmore ET, Gray JA, Brammer MJ. 2001. Time courses of left and right amygdalar responses to fearful facial expressions. Hum Brain Mapp 12(4):193-202.

Phillips ML, Young AW, Scott SK, Calder AJ, Andrew C, Giampietro V, Williams SC, Bullmore ET, Brammer M, Gray JA. 1998. Neural responses to facial and vocal expressions of fear and disgust. Proc Biol Sci 265(1408):1809-17. 
Phillips ML, Young AW, Senior C, Brammer M, Andrew C, Calder AJ, Bullmore ET, Perrett DI, Rowland D, Williams SC and others. 1997. A specific neural substrate for perceiving facial expressions of disgust. Nature 389(6650):495-8.

Rauch SL, Savage CR, Alpert NM, Miguel EC, Baer L, Breiter HC, Fischman AJ, Manzo PA, Moretti C, Jenike MA. 1995. A positron emission tomographic study of simple phobic symptom provocation. Arch Gen Psychiatry 52(1):20-8.

Reiman EM. 1997. The application of positron emission tomography to the study of normal and pathologic emotions. J Clin Psychiatry 58 Suppl 16:4-12.

Robinson DL, Petersen SE. 1992. The pulvinar and visual salience. Trends Neurosci 15(4):12732.

Schienle A, Stark R, Walter B, Blecker C, Ott U, Kirsch P, Sammer G, Vaitl D. 2002. The insula is not specifically involved in disgust processing: an fMRI study. Neuroreport 13(16):2023-6.

Sheehan DV, Lecrubier Y, Sheehan KH, Amorim P, Janavs J, Weiller E, Hergueta T, Baker R, Dunbar GC. 1998. The Mini-International Neuropsychiatric Interview (M.I.N.I.): the development and validation of a structured diagnostic psychiatric interview for DSM-IV and ICD-10. J Clin Psychiatry 59 Suppl 20:22-33;quiz 34-57.

Tillfors M, Furmark T, Marteinsdottir I, Fredrikson M. 2002. Cerebral blood flow during anticipation of public speaking in social phobia: a PET study. Biol Psychiatry 52(11):11139.

Tzourio-Mazoyer N, Landeau B, Papathanassiou D, Crivello F, Etard O, Delcroix N, Mazoyer B, Joliot M. 2002. Automated anatomical labeling of activations in SPM using a macroscopic anatomical parcellation of the MNI MRI single-subject brain. Neuroimage 15(1):273-89.

Van Ameringen M, Mancini C, Szechtman H, Nahmias C, Oakman JM, Hall GB, Pipe B, Farvolden P. 2004. A PET provocation study of generalized social phobia. Psychiatry Res 132(1):138.

van den Heuvel OA, Veltman DJ, Groenewegen $\mathrm{HJ}$, Dolan RJ, Cath DC, Boellaard R, Mesina CT, van Balkom AJ, van Oppen P, Witter MP and others. 2004. Amygdala activity in obsessivecompulsive disorder with contamination fear: a study with oxygen-15 water positron emission tomography. Psychiatry Res 132(3):225-37.

Veltman DJ, Tuinebreijer WE, Winkelman D, Lammertsma AA, Witter MP, Dolan RJ, Emmelkamp PM. 2004. Neurophysiological correlates of habituation during exposure in spider phobia. Psychiatry Res 132(2):149-58.

Vilensky JA, van Hoesen GW. 1981. Corticopontine projections from the cingulate cortex in the rhesus monkey. Brain Res 205(2):391-5.

Wager TD, Phan KL, Liberzon I, Taylor SF. 2003. Valence, gender, and lateralization of functional brain anatomy in emotion: a meta-analysis of findings from neuroimaging. Neuroimage 19(3):513-31.

Ward R, Danziger S, Bamford S. 2005. Response to visual threat following damage to the pulvinar. Curr Biol 15(6):571-3.

Whalen PJ, Bush G, McNally RJ, Wilhelm S, McInerney SC, Jenike MA, Rauch SL. 1998. The emotional counting Stroop paradigm: a functional magnetic resonance imaging probe of the anterior cingulate affective division. Biol Psychiatry 44(12):1219-28.

Williams LM, Das P, Liddell B, Olivieri G, Peduto A, Brammer MJ, Gordon E. 2005. BOLD, sweat and fears: fMRI and skin conductance distinguish facial fear signals. Neuroreport $16(1): 49-52$.

Wright CI, Fischer H, Whalen PJ, McInerney SC, Shin LM, Rauch SL. 2001. Differential prefrontal cortex and amygdala habituation to repeatedly presented emotional stimuli. Neuroreport 12(2):379-83.

Wright CI, Martis B, McMullin K, Shin LM, Rauch SL. 2003. Amygdala and insular responses to emotionally valenced human faces in small animal specific phobia. Biol Psychiatry 54(10):1067-76.

Yamasaki H, LaBar KS, McCarthy G. 2002. Dissociable prefrontal brain systems for attention and emotion. Proc Natl Acad Sci U S A 99(17):11447-51.

Zald DH. 2003. The human amygdala and the emotional evaluation of sensory stimuli. Brain Res Brain Res Rev 41(1):88-123. 



\section{CHAPTER II I}

\section{Amygdala hyperfunction in phobic fear normalizes after exposure}

L. Goossens, S. Sunaert, R. Peeters, E. Griez, K. Schruers

Biological Psychiatry 62 (2007) 1119-1125 


\section{Abstract}

Background: The amygdala is implicated as a key brain structure in fear processing. Studies exploring this process using the paradigm of fear conditioning have implicated the amygdala in fear acquisition and in generating behavioral fear responses. As such, fear extinction could be expected to induce a reduction in amygdala activity. However, exposure in specific phobia has never shown to persistently reduce amygdala activity. Methods: By means of event-related functional magnetic resonance imaging, responses to phobia-related, general threat and neutral pictures were measured before and two weeks after an intensive exposure session in 20 subjects with specific phobia for spiders and compared to healthy controls. Results: Phobics showed increased amygdala activity at baseline. This hyperactivity was significantly reduced two weeks after exposure therapy. Furthermore, a significant reduction of hyperactivity in anterior cingulate cortex and insula was found post-exposure. Conclusions: To our knowledge, this is the first study demonstrating the effect of exposure on the amygdala in specific phobia. Our findings suggest that exposure therapy can have an effect on subcortical structures. 


\section{Introduction}

Studies on the neural correlates of fear implicate the amygdala as a key brain structure. As early as 1939, Kluver and Bucy (Kluver and Bucy, 1939) showed that bilateral removal of the temporal lobe in monkeys resulted in a marked change in emotional behavior, especially the absence of emotional, motor, and vocal reactions normally associated with fear and anger. In subsequent years, other animal lesions studies showed that these deficits could be attributed to the ablation of the amygdala (Horel, et al., 1975; Mishkin and Pribram, 1954; Pribram and Bagshaw, 1953; Schwartzbaum and Poulos, 1965; Weiskrantz, 1956). In humans, damage to the amygdala is associated with loss of the ability to recognize fear in others (Adolphs, et al., 1995).

The amygdala is in an ideal position to regulate the fear response, with its afferent connections converging from all sensory modalities and efferent links to various subcortical structures controlling autonomic reactions (Amaral, et al., 1992). Over the years, fear conditioning studies in rodents have established that the basolateral complex and the central nucleus of the amygdala play an important role in both acquisition and expression of fear (LeDoux, 2000). Neurons in these regions show an increased responsiveness to stimuli after being paired with an aversive stimulus (Applegate, et al., 1982; Quirk, et al., 1995). Human neuroimaging studies have revealed amygdala activation in response to visual and vocal expressions of fear (Morris, et al., 1996; Whalen, et al., 1998). In addition, fear conditioning studies have confirmed the role of the amygdala in fear acquisition using functional magnetic resonance imaging (fMRI) (Cheng, et al., 2003; LaBar, et al., 1998). Other brain structures linked to threat processing are the insula, the anterior cingulate and the fusiform cortex.

It is interesting not only to study the mechanisms of the brain underlying fear acquisition, but also to establish which areas of the brain are involved in the alleviation of fear. Given the pivotal role it plays in the acquisition of fear, it is not surprising that the amygdala is thought to be involved in extinction of fear as well; however, its role there is less clear. Previous research on extinction of learned fear in animals alludes to the interaction between the medial prefrontal cortex (MPFC) and the amygdala. It has been proposed that the MPFC regulates the communication between the lateral and central nucleus of the amygdala, inhibiting the amygdala from sending output signals to regions of the brain necessary for the physiological expression of conditioned fear (Morgan, et al., 1993; Quirk and Gehlert, 2003; Rosenkranz, et al., 2003). There are only a few studies on the extinction process in humans. One important study by Phelps et al. (Phelps, et al., 2004) assessed the involvement of the amygdala and the mPFC during extinction learning in humans using fMRI. The amygdala response in 
this study was characterized by an increase in activation to the paired stimulus $\left(\mathrm{CS}^{+}\right)$relative to a stimulus which was never paired (CS) only during acquisition. The ventromedial PFC (VmPFC) was active during all stages of learning, but its activity seemed to be primarily linked to the conditioned response during the retention of extinction learning.

A naturalistic and realistic model to study fear alleviation in humans is exposure therapy in the clinical condition 'specific phobia'. People suffering from specific phobia show an exaggerated fear response to a well-defined stimulus. During exposure therapy, patients are gradually exposed to the phobic stimulus until fear eventually subsides. However, little is known about the neural mechanisms of this beneficial effect. Studying the neural correlates of fear alleviation in this model may therefore provide useful insights into the mechanisms of action of fear extinction in humans.

To our knowledge, there are only two studies on specific phobia that explore the changes in the brain after successful treatment. Paquette and colleagues (Paquette, et al., 2003) found that hyperactivity, in response to phobicrelevant stimuli seen in the dorsolateral PFC (dIPFC) and the parahippocampal gyrus decreased after treatment. The most recent study by Straube et al. (Straube, et al., 2006) showed reduced activation in the anterior cingulate cortex (ACC), the insula and the thalamus. These regions were more active in phobics before treatment compared to controls.

Surprisingly, despite the widely accepted role of the amygdala in fear, the abovementioned studies do not report on hyperactivity of this brain area before treatment, or on reduced activation after treatment. This is at odds with most studies of affective stimulus processing and Pavlovian fear conditioning, both in humans and animals. This incongruence may be linked to the use of a block design and the rapid habituation of the amygdala. It has been suggested that presentation of stimuli in blocks of a certain amount of time may cause habituation of rapid amygdala responses (see (Breiter, et al., 1996; Buchel, et al., 1998).

The present study examines the neurofunctional changes associated with fear alleviation in phobic subjects treated with behavioral exposure therapy using event-related fMRI (er-fMRI). Data analysis is focused on the amygdala, given its previously established involvement in fear. Moreover, this study explores the effect of reduced fear on those brain regions found to be active in a symptom provocation study performed earlier by our group (Goossens, et al., 2007), namely: the ACC, the insula and the dorsal thalamus. 


\section{Methods and Materials}

\section{Subjects}

Participants were 20 right-handed female subjects with spider phobia (mean age: $24 \pm 3.02$ ), as well as 12 female and 2 male right-handed control subjects. Right-handedness was assessed with the Edinburgh Handedness Inventory (Oldfield, 1971).

All participants were recruited by public advertisement at the Leuven University and Academic Hospital. Phobic subjects were diagnosed prior to the experiment using a structured psychiatric interview [Mini International Neuropsychiatric Interview, MINI, (Sheehan, et al., 1998)]. In addition, they had a high score (mean $=23.05, \mathrm{SD}=2.88$ ) on the self-administered Spider Phobia Questionnaire [SPQ (Klorman, et al., 1974)]. None of the spider phobics had ever received treatment for their phobia. Control subjects did not show any signs of phobia (SPQ mean $=2, \mathrm{SD}=1$ ). The control subjects were taken from our previous study (24) and were matched for age. Both controls and phobics were free of medication and of additional lifetime psychopathology according to the MINI.

Four spider phobic subjects had to be excluded for the following reasons: no participation in the second scanning session, snake phobia, image corruption, and non-involvement in therapy leading to early discontinuation. A sample of 16 spider phobic subjects was used in the analysis. Written informed consent was obtained from each participant prior to the experiment. The study was approved by the local ethics committee.

\section{Stimuli and tasks}

During scanning, all subjects were exposed to a series of spider (phobiarelevant), snake (potentially fear-relevant), and neutral stimuli, taken from the International Affective Picture System, and to a fixation cross as a null event (27 pictures from each category). The snakes were introduced to control for possible hyperreactivity to general threat-related stimuli. All stimuli were equated for visual content.

Pictures were presented in a random order for $1 \mathrm{~s}$ each with a variable interstimulus interval of $2.25 \mathrm{~s}$ to $9 \mathrm{~s}$ between succeeding stimuli. The pictures were viewed by means of a mirror attached to the head coil. The instruction was given to look attentively at the stimuli.

Spider phobic subjects underwent two scanning sessions: approximately one week before and two weeks after the therapy session; controls subjects had only one fMRI session (fig.1). Before the scanning sessions, spider phobic participants rated the fear induction of the spider and snake pictures on the Visual Analogue Anxiety Scale (VAAS; $0=$ no fear at all to $100=$ worst fear), and the valence and arousal on a scale ranging from -100 to $100(-100=$ most unpleasant $/$ not arousing, $100=$ most pleasant $/$ most arousing). $A$ 
repeated measures analysis of variance (ANOVA) in SPSS was used to analyze the behavioral data. A Bonferroni correction was applied for the post-hoc comparisons. A probability level of $P<0.05$ was considered statistically significant.

\section{Therapy and therapy outcome measurements}

The cognitive behavioral therapy was based on the one-session treatment by Öst (Ost, 1989) consisting of a combination of exposure in vivo and modeling. Therapy sessions were conducted one week after the first scanning procedure and two weeks before the second. All therapy sessions lasted 4-5 $\mathrm{h}$ and were given by an experienced psychiatrist/cognitive behavioral therapist (KS.) in small groups ( 3 to 5 persons).

Sessions always started with a problem analysis for each subject, general education of the types of misbelieves about the danger of spiders, and the main psychological reasons for the maintenance of fear reactions. Every hierarchical step in the exposure therapy was explained explicitly beforehand. Therapy only progressed to the next level of difficulty after consent of all participants. Subjects were exposed to spider-related material in a hierarchical fashion, beginning with their own drawings and pictures. At the end of each exposure step, the anxiety level on the VAAS (anxiety scale ranging from 0 to 100) had to be lowered by $30 \%$ before continuing on to the next step, meaning that all subjects were able to perform that part of the treatment without strong feelings of anxiety. Last steps included handling living domestic spiders. In the end, all subjects were able to touch their phobic object.

Additional outcome measures included the SPQ, as well as fear, arousal and valence ratings immediately before the second scanning session.

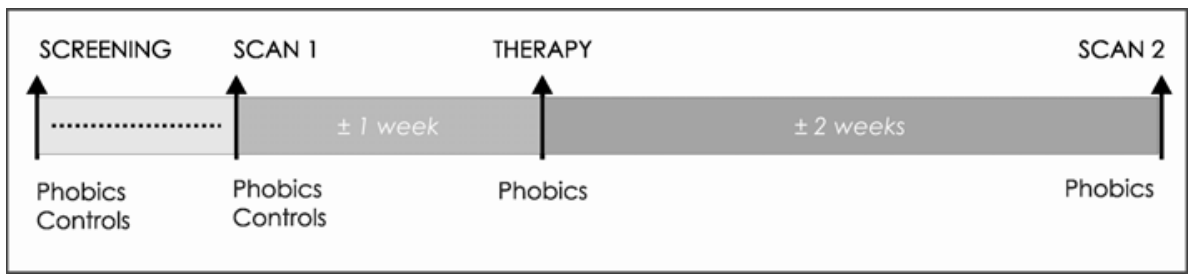

Fig. 1: Schematic overview of the study design

\section{fMRI}

Brain images were acquired using a 3.0 Tesla Philips Intera scanner. Structural image acquisition consisted of a $\mathrm{T}_{1}$-weighted 3D TFE scan with a resolution of $1 \mathrm{~mm}$ isotropically. For functional images, 225 images were acquired per time series for every subject using a $\mathrm{T}_{2}{ }^{*}$-weighted gradient echo echo planar imaging sequence (GE-EPI) with 28 axial slices (slice 
thickness $=4.5 \mathrm{~mm}$, gap $=0.5 \mathrm{~mm})$ covering the whole brain $(\mathrm{TR}=2 \mathrm{~s}$, TE $=30 \mathrm{~ms}, \mathrm{FOV}=230 \times 230$, matrix $=80 \times 80$, SENSE reduction factor $=2.5$ ). Three time series were recorded for each subject.

For the preprocessing and statistical analyses, the statistical parametric mapping software package (SPM2, Wellcome Departement of Cognitive Neurology, London) implemented in Matlab (Mathworks, Natick, Mass., USA, release 13) was used. The functional images were realigned to the first volume of time series to correct for head movements (four dummy images at the beginning of each time series were discarded for further analysis), and slice timing was applied to correct for differences in acquisition time during scanning. After co-registering the functional images to the anatomical image, they were spatially normalized to the standard space of the Montreal Neurological Institute brain (MNI-brain). All functional images were subsampled to a voxel size of $2 \times 2 \times 2 \mathrm{~mm}$ and smoothed with a Gaussian kernel of $10 \mathrm{~mm}$ full width at half maximum (FWHM).

First-level statistical analysis was done for all subjects in the context of the General Linear Model. Each of the experimental conditions (spider, snake, neutral, and fixation) was modeled by a boxcar function convolved with a hemodynamic response function with its time derivatives and their parametric modulation over time in the general linear model (GLM). Tcontrasts for "Spider>Neutral", "Snake>Neutral", and "Spider>Snake" were calculated for each subject. The individual contrast images were used in a second-level random effects analysis, which accounts for both scan-to-scan and subject-to-subject variability, to determine stimuli-specific regional responses for within- and between-group statistical comparisons. Further, second-level correlation analyses were carried out in SPM2 on pre and post images with the SPQ and the VAAS. The results of the exploratory analysis are reported at $P<0.05$, corrected for multiple comparisons using the False Discovery Rate (FDR) (Genovese, et al., 2002).

Because of an a priori hypothesis regarding the response in the amygdala, a region of interest (ROI) analysis was conducted in this area of the brain. ROIs were also drawn for the anterior cingulate cortex and the insula based on the results of a previous study (24). The ROIs were defined by the anatomical parcellation of the normalised brain (single subject highresolution T1 volume of the Montreal Neurological Institute) as described by (Tzourio-Mazoyer, et al., 2002). The significance level was set at $P<0.05$, and corrected for the specific volume of interest.

\section{Results}

\section{Behavioral data}

Descriptive data of the rating scales are depicted in table I. There was a main effect of treatment (pre-post) and stimulus (spider-snake) for the fear 
[treatment: $F(1,15)=65.89 ;$ stimulus: $F(1,15)=115.89$ ] and valence [treatment: $F(1,15)=20.23$; stimulus: $F(1,15)=74.71$ ] ratings. There was also a significant interaction of treatment by stimulus [Fear: $F(1,15)=48.00$; Valence: $F(1,15)=11.93)$. Post-hoc comparisons revealed that the spiders were perceived as more fearful and negative than the snakes. This difference was still present after treatment. Nonetheless, fear $(t=8.87)$ and valence $(t=-8.18)$ scores for the spider pictures were significantly lower two weeks after the exposure session.

Table I. Descriptive behavioral data

\begin{tabular}{lllllll}
\hline Variable & Scan 1 & \multicolumn{3}{c}{ Scan 2 } & \multicolumn{3}{c}{ Controls $(\mathbf{n = 5 )}$} \\
\cline { 2 - 7 } & Mean & SEM & Mean & SEM & Mean & SEM \\
\hline SPQ & 23.31 & $(0.74)$ & 12.63 & $(1.34)$ & 1.43 & $(0.29)$
\end{tabular}

$\begin{array}{lllllll}\text { Fear } & & & & & & \\ \text { Spider } & 73.75 & (4.11) & 37.63 & (6.19) & 13.20 & \text { (3.72) } \\ \text { Snake } & 13.69 & (3.46) & 7.90 & (2.39) & 18.85 & \text { (6.28) }\end{array}$

Valence

$\begin{array}{lllllll}\text { Spider } & -70.19 & (45.32) & -31.79 & (6.08) & -1.95 & \text { (11.02) } \\ \text { Snake } & 5.53 & (4.92) & 20.31 & (8.79) & 5 & (9.81)\end{array}$

Arousal

\begin{tabular}{lllllll} 
Spider & 58.21 & $(5.88)$ & -1.85 & $(10.31)$ & -8.95 & $(8.86)$ \\
Snake & -24.50 & $(8.79)$ & -55.35 & $(9.99)$ & -3.55 & $(8.80)$ \\
\hline
\end{tabular}

\section{I maging data}

Left amygdala between-group ROI analysis for the contrast 'spider > neutral' revealed higher brain activation in the phobic subjects before treatment than in the controls. However, this differential brain response disappeared after treatment, meaning that the phobics showed no significantly higher left amygdala activity than controls during their second scanning session two weeks after treatment (fig. 2).

A paired t-test comparing the fMRI data of the phobic subjects before and after treatment session confirmed a significant reduction in activation in the left amygdala following exposure therapy (Talairach coordinates and statistical values of peak activation: $-18,-1,-10 ; \mathrm{t}=4.35)$. Furthermore, the percentage of change in BOLD-response for 'spider-neutral' in the amygdala positively correlated with the SPQ-score as well as with the VAAS scores for 
the spider pictures (fig. 3), meaning that a higher SPQ or VAAS score corresponds to a higher BOLD signal for spiders than for neutral pictures.

Compared to the control group, phobics exhibited significantly greater responses bilaterally in the ACC and the insular cortex. As was the case with the amygdala, the increased responses in phobics at the ACC and insula had normalized by the second scanning session (fig. 4). A paired t-test directly comparing the pre and post scanning data of the phobic group demonstrated a significantly lower activation of these areas of the brain during the second scanning session.

The contrast 'spider>snake' confirmed that the activation in phobic subjects at the anterior ACC and the left insula was phobia-specific (table II).

Contrasting the imaging data of post-treatment scans with controls only showed significant increased activation in secondary visual areas. The control group did not show any significant increases for the contrast 'spiderneutral', compared to either the pre-treatment, or post-treatment scanning session of the phobic group.

Table II. p- and t-values for the contrast 'spider>snake'

\begin{tabular}{lcccc}
\hline Analysis: & \multicolumn{2}{c}{ Pre>Controls } & \multicolumn{2}{c}{ Pre>Post } \\
\cline { 2 - 5 } & $t$-value & $p$-value & $t$-value & $p$-value \\
\hline ACC & 3.44 & 0.00 & 3.34 & 0.00 \\
Left I nsula & 1.76 & 0.04 & 3.08 & 0.00 \\
Left Amygdala & 0.98 & 0.42 & 1.38 & 0.24
\end{tabular}

\section{Discussion}

The present study revealed a decrease in amygdala activity in spider phobics after behavioral exposure therapy compared to pre-treatment. In the phobic group, left amygdala activation was positively correlated with the anxiety scores for the specific phobic stimuli as well as with the severity of spider phobia in general. In addition, the current findings confirmed the normalization of the insula and ACC response found by Straube et al. (2006).

The left amygdala hyperactivity in the phobic group at baseline was consistent with activation found in a previous study performed by our group (Goossens et al., 2007). As hypothesized, differential amygdala activation was revealed before and after the treatment session. The activation of the amygdala cluster was normalized by the second scanning session. To our knowledge, this is the first study demonstrating a normalization of amygdala hyperactivity after exposure therapy in specific phobia. However, it is noteworthy to mention that amygdala activation after therapy for the 
contrast 'spider-snake' did not reach significance. This is probably due to the selection criteria allowing for a certain variation in the degree of fear for snakes. In the case of snakes, only the categorical question "phobia or not" was assessed, while fear for spiders was assessed in a categorical as well as in a dimensional way (SPQ). This might have led to a slight activation of the amygdala in response to snake pictures in some subjects, introducing a somewhat higher variability in the direct comparison between spiders versus snakes. This may explain the amygdala activation being just below the threshold.

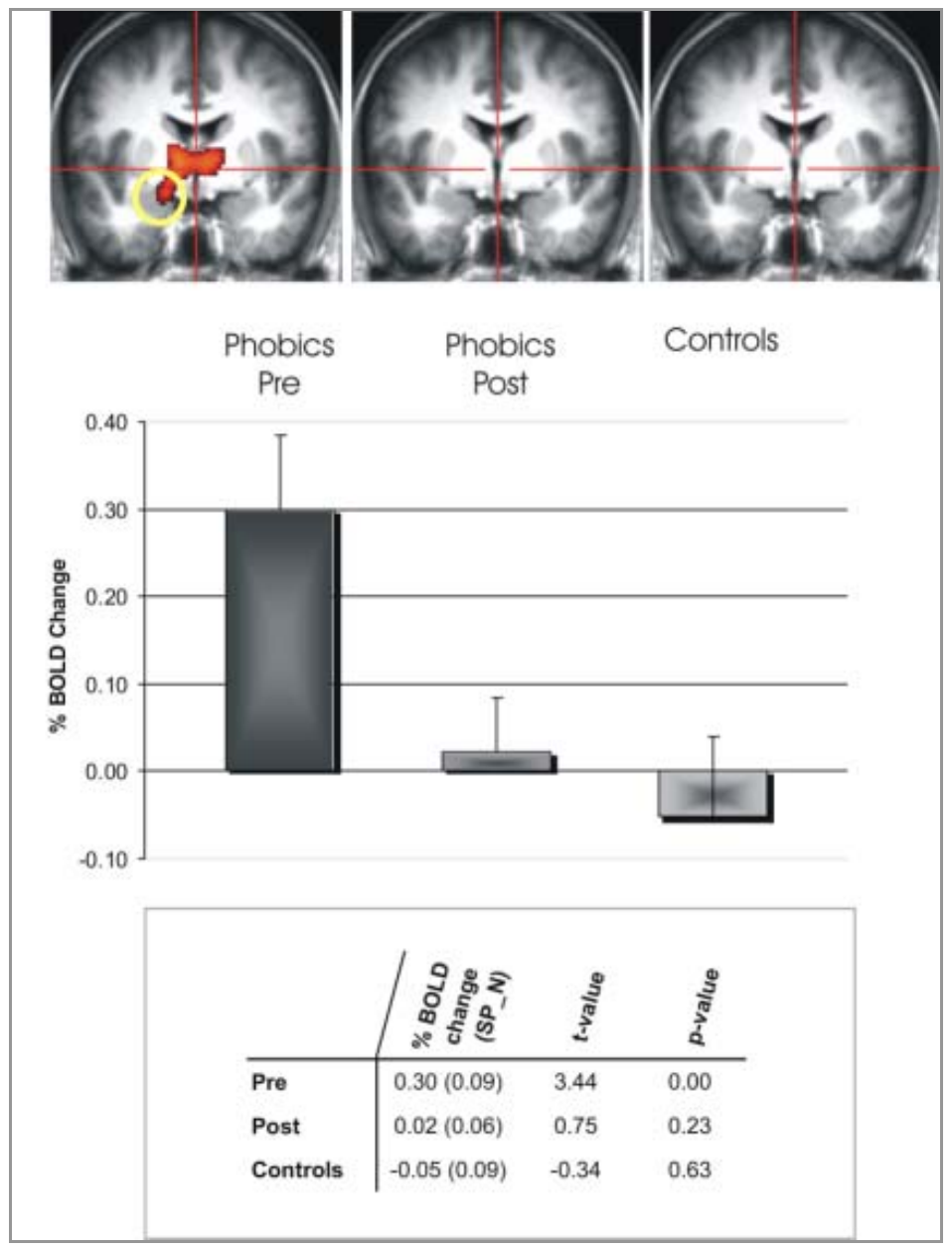

Fig. 2: Top: Activation maps showing significantly more BOLD signal to spiders than to neutral pictures at baseline, post treatment, and in controls. Middle: Plots showing the percentage of increase in BOLD signal to spiders compared to neutral pictures. Bottom: Descriptive data of the ROI analysis at the amygdala 
Previously conducted neuroimaging studies on exposure therapy in specific phobia did not report on amygdala hyperactivity before treatment or on reduced activation after treatment (Paquette et al., 2003; Straube et al., 2006). This may be due to the difference in stimulus paradigm. Both studies applied a prolonged stimulus presentation by means of film clips. It has been demonstrated that the amygdala shows habituation over conditioning trials or presentations of affective stimuli (Buchel et al., 1998; LaBar et al., 1998; Wright et al., 2001). The amygdala has even shown within-trial habituation to threat cues (Phelps et al., 2001). Hence, the design of prolonged stimulus presentation may have caused habituation; therefore, this type of design may be less appropriate to capture amygdala activation. Recently, event-related fMRI stimulus designs (Dilger et al., 2003; Goossens, et al., 2007) and PET designs with very brief stimuli (Carlsson et al., 2004) were able to reveal amygdala activation in specific phobia. In addition, another recent study suggests that the difference in amygdala activation between phobics and controls to spider pictures is due to a faster time in onset and time to peak in the phobic subjects (Larson et al., 2006). To detect the rapid amygdala signal, an event-related paradigm was used in the present study. Furthermore, it is worth mentioning that a treatment study in social phobia (Furmark et al., 2002) also reported reduced cerebral blood flow in the left amygdala during a public speaking task after cognitive behavioral therapy compared to pre-treatment. The therapy included simulated exposures to feared situations.

As stated earlier, the amygdala has been implicated in fear acquisition in both animal and human studies (Buchel et al., 1998; Knight et al., 2004; LaBar et al., 1998; Morris, et al., 2001). Animal (rodent) studies point to the basolateral nucleus as an ideal place for the convergence of the conditioned and the paired aversive stimulus.

The role of the amygdala in fear extinction is less clear. Animal studies have demonstrated that neuronal firing at the lateral amygdala in response to a conditioned stimulus diminishes over time when no longer paired with the unconditioned stimulus (Quirk et al., 1995; Repa et al., 2001). Human fear conditioning studies exploring amygdala activation during acquisition and extinction support the above animal studies. When comparing activity during acquisition phase to that in the extinction phase, Knight et al. (2004) found an increase in left amygdala activation. Phelps and colleagues (2004) looked at activation for the contrast ' $\mathrm{CS}^{+}>\mathrm{CS}^{-1}$ during both phases. They showed an increase in amygdala activity during acquisition, but not during extinction. The decreased amygdala activity after exposure therapy in the present study is, therefore, consistent with the abovementioned results in human fear conditioning studies. This kind of therapy can be seen as a naturalistic and clinically relevant approach to the extinction procedure.

Further research has suggested that the amygdala does not only play a role in fear acquisition, but also in generating behavioral fear responses. Angrilli 
and colleagues (Angrilli et al., 1996) described a man with right amygdala damage showing a reduced startle response to a sudden burst of noise. Several fear conditioning studies also point out that the amygdala is correlated with conditioned skin conductance responses (Cheng et al., 2003; Phelps et al., 2004). Therefore, the decrease in the present study can be linked to a decrease in the fear response evoked by a spider. All treated phobic volunteers subjectively reported experiencing a diminished fear reaction to spiders. This is reflected in the reduced fear and SPQ scores two weeks after the treatment session.

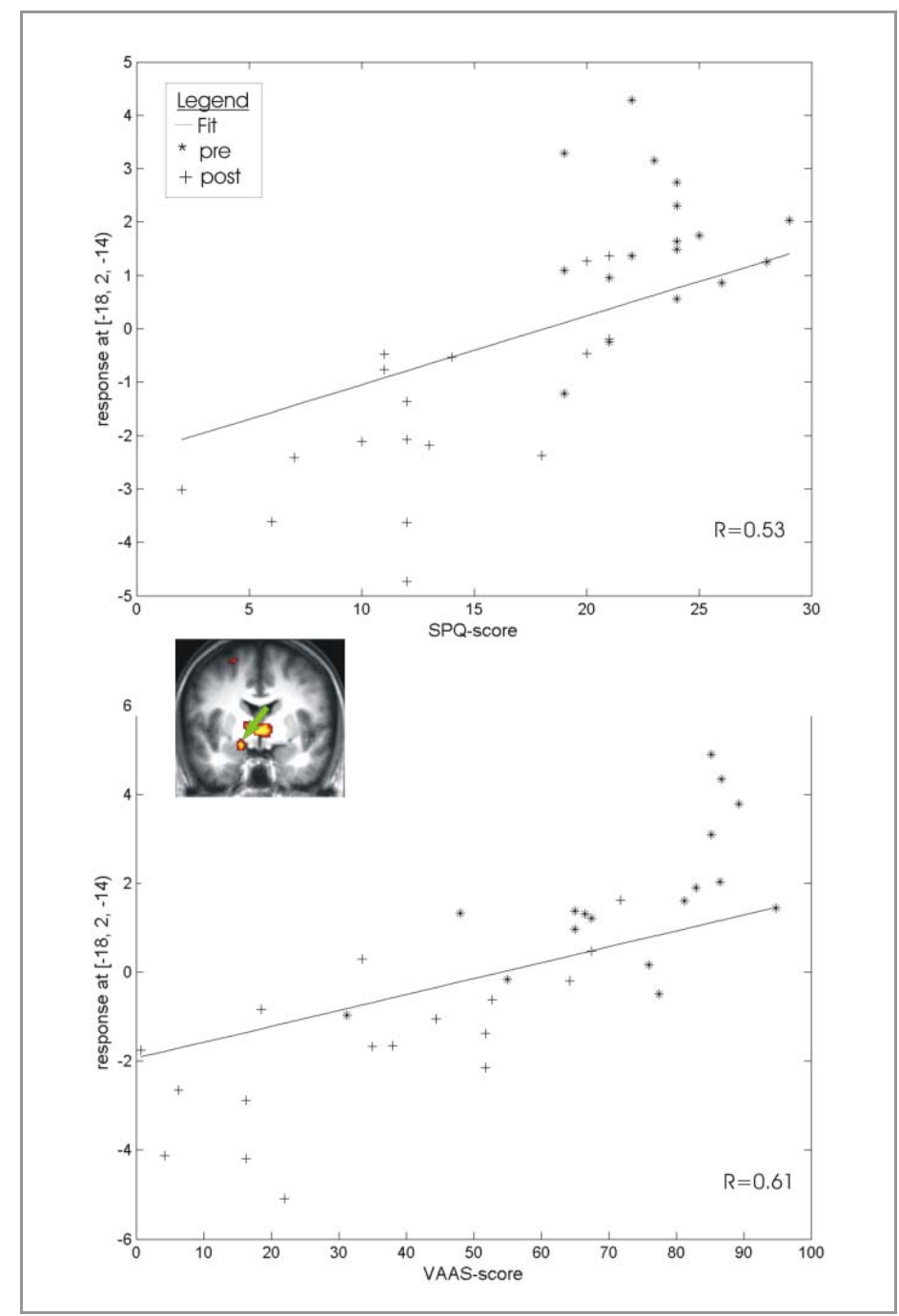

Fig. 3: Positive correlation at the amygdala with SPQ and the VAAS scores for pre and post images 
The amygdala has direct connections with the ACC and the insula. Both areas were involved in the network showing hyperactivation before treatment which was normalized during the second scan two weeks after the intensive exposure session.

In the present study, the ACC activation was located in the dorsal part, comparable to the cluster found by Straube et al. (2006). This region projects to brainstem autonomic centers (An et al., 1998; Ongur et al., 1998; Vilensky and van Hoesen, 1981) and has strong connectivity with primary and supplementary motor areas (Paus, 2001; Picard and Strick, 1996). Over the years, a function of 'conflict monitoring' has been ascribed to this area of the brain. Evidence for this evolved from studies with tasks involving response override, undetermined responding and error commission (e.g., stroop and flanker tasks) (for review see (Botvinick, et al., 2004). Furthermore, the dorsal ACC (dACC) has been implicated in the elicitation and control of sympathetic autonomic arousal. As such, activity in the dACC is correlated with alterations in cardiovascular en electrodermal responses to a range of cognitive, emotional and motivational tasks (Critchley et al., 2004; Gianaros et al., 2005). From the above, the dACC can be seen as an integration cortex to detect external events and internal states and to adjust behavioral response accordingly.

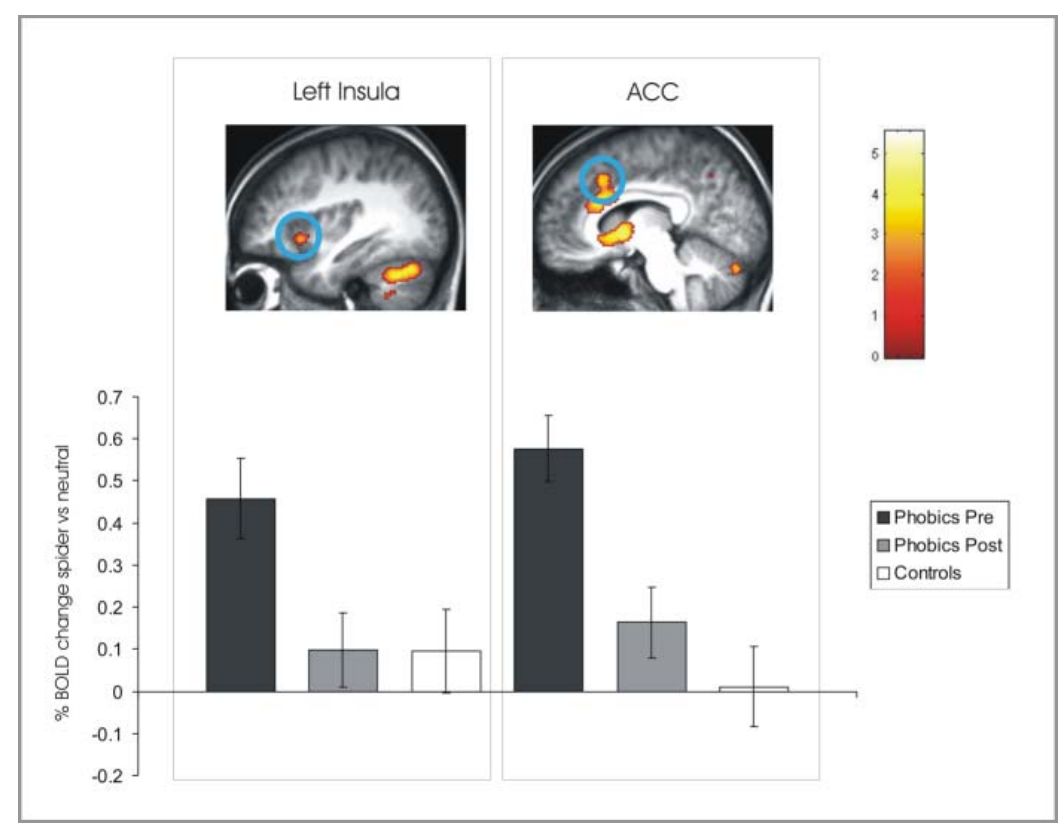

Fig. 4: Activation maps showing significantly more BOLD signal in the phobics at baseline than at post treatment for the contrast 'spider-neutral'. The plots display the percentage of increase in BOLD signal to spiders compared to neutral pictures. 
The insular cortex is also activated during states of autonomic arousal (Aziz et al., 2000; Buchel et al., 1998; Craig et al., 2000; Critchley et al., 2003), usually in concert with the ACC. This structure has a unique position in mediating between sensory input, the autonomic/visceral systems, and other regions of the brain involved in higher order processing (Wright et al., 2003). This part of the cortex seems to be implicated in the representation of internal bodily states. Information about the interoceptive state is relayed to the ACC which can generate the appropriate response (Carter et al., 1999).

Taken together, this suggests that both the reduced ACC and insula activity may be due to a decreased state of arousal upon confrontation with spider stimuli after therapy.

The lack of a control group of untreated phobics is the main limitation of the present study. However, it is worth mentioning that the present study included three spider phobics who participated in a previous study on spider phobia conducted by our group using the same event related paradigm. The scanning sessions of these two studies were separated by approximately 8 months. The overall activation maps of these subjects for the contrast 'Spider-Neutral' did not differ between the scan of the previous and that of the present study. Future studies including a waiting group or a sham therapy group would be useful to further clarify whether the observed effect is due to the intervention or to spontaneous improvement of the clinical condition of the participants. The positive correlation between the severity of spider phobia in general, reflected in the SPQ score, and the amygdala activity favors the intervention effect.

To a lesser extent, the study is also limited by the single scan of the control group. This could account for test-retest effects. Given the fact that controls were taken from a former study, behavioral ratings can not be reported for this group. However, effort was done to reinvite controls to rate the stimuli. Only five of them responded (see table 1).

The absence of vmPFC activation is somewhat unexpected. Rodent studies point to inhibitory top-down control of the vmPFC in the extinction process. The design of these studies mostly involves lesions or inactivations of the PFC which result in an impairment in extinction recall 24 hours after training (Quirk et al., 2000; Sierra-Mercado et al., 2006). In human studies, prefrontal involvement in top-down control is demonstrated in so called "suppression" and "reappraisal" paradigms (see overview in (Quirk and Beer, 2006). However, these designs are not completely comparable to the design of the present study: In reappraisal and suppression paradigms, the subjects are asked to actively control their thoughts or behavior, whereas in the present study they were only asked to passively view pictures. Human studies examining the extinction of conditioned fear are more closely related 
to exposure therapy as applied in the current study. One such study by Phelps (2004) found a positive correlation between vmPFC signal during recall and success during extinction training. A very recent study (Milad, et al., 2007) compared an extinguished versus a non-extinguished stimulus. A positive correlation between the percentage signal change in the vMPFC and extinction retention was found. From the above findings, one could hypothesize that increased activation in the vmPFC was to be expected in the post treatment images. However, this was not the case in the present study, nor was it in the study conducted by Straube et al. (2006). It is known that the vmPFC is a very difficult area to image at 3T. However, a reanalysis of the present data with 12 subjects having good signal at the vmPFC, did not change the results. Furthermore, we have to take into account that the above mentioned studies only tested extinction in a 24 hours interval. A recent study (Myers et al., 2006) shows evidence for different mechanisms of fear extinction dependent on the length of time since fear acquisition. It is also worth mentioning that inactivation of the vmPFC after extinction training does not impair extinction recall (Wright et al., 2003). This finding implies that other areas could be involved in extinction expression.

In the present study, subjects are scanned two weeks after the exposure session. It is conceivable that the mPFC reflects ongoing suppression of the amygdala that may subside later on. Hence, long-term extinction could be supported elsewhere in the brain.

Further studies focusing on short-term and long-term effects of extinction should clarify this. 


\section{References}

Adolphs R, Tranel D, Damasio H, Damasio AR. 1995. Fear and the human amygdala. J Neurosci 15(9):5879-91.

Amaral DG, Price JL, Pitkanen A, Carmichael ST. 1992. Anatomical organization of the primate amygdaloid complex. In: Aggleton JP, editor. The amygdala: Neurobiological aspects of emotion, memory, and mental dysfunction. New York: Wiley-Liss. p 1-66.

An X, Bandler R, Ongur D, Price JL. 1998. Prefrontal cortical projections to longitudinal columns in the midbrain periaqueductal gray in macaque monkeys. J Comp Neurol 401(4):455-79.

Angrilli A, Mauri A, Palomba D, Flor H, Birbaumer N, Sartori G, di Paola F. 1996. Startle reflex and emotion modulation impairment after a right amygdala lesion. Brain 119 ( Pt 6):1991-2000.

Applegate CD, Frysinger RC, Kapp BS, Gallagher M. 1982. Multiple unit activity recorded from amygdala central nucleus during Pavlovian heart rate conditioning in rabbit. Brain Res 238(2):457-62.

Aziz Q, Schnitzler A, Enck P. 2000. Functional neuroimaging of visceral sensation. J Clin Neurophysiol 17(6):604-12.

Botvinick MM, Cohen JD, Carter CS. 2004. Conflict monitoring and anterior cingulate cortex: an update. Trends Cogn Sci 8(12):539-46.

Breiter HC, Etcoff NL, Whalen PJ, Kennedy WA, Rauch SL, Buckner RL, Strauss MM, Hyman SE, Rosen BR. 1996. Response and habituation of the human amygdala during visual processing of facial expression. Neuron 17(5):875-87.

Buchel C, Morris J, Dolan RJ, Friston KJ. 1998. Brain systems mediating aversive conditioning: an event-related fMRI study. Neuron 20(5):947-57.

Carlsson K, Petersson KM, Lundqvist D, Karlsson A, Ingvar M, Ohman A. 2004. Fear and the amygdala: manipulation of awareness generates differential cerebral responses to phobic and fear-relevant (but nonfeared) stimuli. Emotion 4(4):340-53.

Carter CS, Botvinick MM, Cohen JD. 1999. The contribution of the anterior cingulate cortex to executive processes in cognition. Rev Neurosci 10(1):49-57.

Cheng DT, Knight DC, Smith CN, Stein EA, Helmstetter FJ. 2003. Functional MRI of human amygdala activity during Pavlovian fear conditioning: stimulus processing versus response expression. Behav Neurosci 117(1):3-10.

Craig AD, Chen K, Bandy D, Reiman EM. 2000. Thermosensory activation of insular cortex. Nat Neurosci 3(2):184-90.

Critchley HD, Mathias CJ, Josephs O, O'Doherty J, Zanini S, Dewar BK, Cipolotti L, Shallice T, Dolan RJ. 2003. Human cingulate cortex and autonomic control: converging neuroimaging and clinical evidence. Brain 126(Pt 10):2139-52.

Critchley HD, Wiens S, Rotshtein P, Ohman A, Dolan RJ. 2004. Neural systems supporting interoceptive awareness. Nat Neurosci 7(2):189-95.

Dilger S, Straube T, Mentzel HJ, Fitzek C, Reichenbach JR, Hecht H, Krieschel S, Gutberlet I, Miltner WH. 2003. Brain activation to phobia-related pictures in spider phobic humans: an event-related functional magnetic resonance imaging study. Neurosci Lett 348(1):29-32.

Furmark T, Tillfors M, Marteinsdottir I, Fischer H, Pissiota A, Langstrom B, Fredrikson M. 2002. Common changes in cerebral blood flow in patients with social phobia treated with citalopram or cognitive-behavioral therapy. Arch Gen Psychiatry 59(5):425-33.

Genovese CR, Lazar NA, Nichols T. 2002. Thresholding of statistical maps in functional neuroimaging using the false discovery rate. Neuroimage 15(4):870-8.

Gianaros PJ, May JC, Siegle GJ, Jennings JR. 2005. Is there a functional neural correlate of individual differences in cardiovascular reactivity? Psychosom Med 67(1):31-9.

Goossens L, Schruers K, Peeters R, Griez E, Sunaert S. 2007. Visual presentation of phobic stimuli: amygdala activation via an extrageniculostriate pathway? Psychiatry Research: Neuroimaging In press.

Horel JA, Keating EG, Misantone LJ. 1975. Partial Kluver-Bucy syndrome produced by destroying temporal neocortex or amygdala. Brain Res 94(2):347-59. 
Klorman R, Weerts TC, Hastings JE, Melamed BG, Lang PJ. 1974. Psychometric description of some specific-fear questionnaires. Behavior therapy 5:401-409.

Kluver H, Bucy PC. 1939. Preliminary analysis of function of the temporal lobes in monkeys. Archives of Neurology 42:979-1000.

Knight DC, Smith CN, Cheng DT, Stein EA, Helmstetter FJ. 2004. Amygdala and hippocampal activity during acquisition and extinction of human fear conditioning. Cogn Affect Behav Neurosci 4(3):317-25.

LaBar KS, Gatenby JC, Gore JC, LeDoux JE, Phelps EA. 1998. Human amygdala activation during conditioned fear acquisition and extinction: a mixed-trial fMRI study. Neuron 20(5):937-45.

Larson CL, Schaefer HS, Siegle GJ, Jackson CA, Anderle MJ, Davidson RJ. 2006. Fear is fast in phobic individuals: amygdala activation in response to fear-relevant stimuli. Biol Psychiatry 60(4):410-7.

LeDoux JE. 2000. Emotion circuits in the brain. Annu Rev Neurosci 23:155-84.

Milad MR, Wright CI, Orr SP, Pitman RK, Quirk GJ, Rauch SL. 2007. Recall of Fear Extinction in Humans Activates the Ventromedial Prefrontal Cortex and Hippocampus in Concert. Biol Psychiatry.

Mishkin M, Pribram KH. 1954. Visual discrimination performance following partial ablations of the temporal lobe. I. Ventral vs. lateral. J Comp Physiol Psychol 47(1):14-20.

Morgan MA, Romanski LM, LeDoux JE. 1993. Extinction of emotional learning: contribution of medial prefrontal cortex. Neurosci Lett 163(1):109-13.

Morris JS, Buchel C, Dolan RJ. 2001. Parallel neural responses in amygdala subregions and sensory cortex during implicit fear conditioning. Neuroimage 13(6 Pt 1):1044-52.

Morris JS, Frith CD, Perrett DI, Rowland D, Young AW, Calder AJ, Dolan RJ. 1996. A differential neural response in the human amygdala to fearful and happy facial expressions. Nature 383(6603):812-5.

Myers KM, Ressler KJ, Davis M. 2006. Different mechanisms of fear extinction dependent on length of time since fear acquisition. Learn Mem 13(2):216-23.

Oldfield RC. 1971. The assessment and analysis of handedness: the Edinburgh inventory. Neuropsychologia 9:97-113.

Ongur D, An X, Price JL. 1998. Prefrontal cortical projections to the hypothalamus in macaque monkeys. J Comp Neurol 401(4):480-505.

Ost LG. 1989. One-session treatment for specific phobias. Behav Res Ther 27(1):1-7.

Paquette V, Levesque J, Mensour B, Leroux JM, Beaudoin G, Bourgouin P, Beauregard M. 2003. "Change the mind and you change the brain": effects of cognitive-behavioral therapy on the neural correlates of spider phobia. Neuroimage 18(2):401-9.

Paus T. 2001. Primate anterior cingulate cortex: where motor control, drive and cognition interface. Nat Rev Neurosci 2(6):417-24.

Phelps EA, Delgado MR, Nearing KI, LeDoux JE. 2004. Extinction learning in humans: role of the amygdala and vmPFC. Neuron 43(6):897-905.

Phelps EA, O'Connor KJ, Gatenby JC, Gore JC, Grillon C, Davis M. 2001. Activation of the left amygdala to a cognitive representation of fear. Nat Neurosci 4(4):437-41.

Picard N, Strick PL. 1996. Motor areas of the medial wall: a review of their location and functional activation. Cereb Cortex 6(3):342-53.

Pribram KH, Bagshaw M. 1953. Further analysis of the temporal lobe syndrome utilizing frontotemporal ablations. J Comp Neurol 99(2):347-75.

Quirk GJ, Beer JS. 2006. Prefrontal involvement in the regulation of emotion: convergence of rat and human studies. Curr Opin Neurobiol 16(6):723-7.

Quirk GJ, Gehlert DR. 2003. Inhibition of the amygdala: key to pathological states? Ann N Y Acad Sci 985:263-72.

Quirk GJ, Repa C, LeDoux JE. 1995. Fear conditioning enhances short-latency auditory responses of lateral amygdala neurons: parallel recordings in the freely behaving rat. Neuron 15(5):1029-39.

Quirk GJ, Russo GK, Barron JL, Lebron K. 2000. The role of ventromedial prefrontal cortex in the recovery of extinguished fear. J Neurosci 20(16):6225-31. 
Repa JC, Muller J, Apergis J, Desrochers TM, Zhou Y, LeDoux JE. 2001. Two different lateral amygdala cell populations contribute to the initiation and storage of memory. Nat Neurosci 4(7):724-31.

Rosenkranz JA, Moore $H$, Grace AA. 2003. The prefrontal cortex regulates lateral amygdala neuronal plasticity and responses to previously conditioned stimuli. J Neurosci 23(35):11054-64.

Schwartzbaum JS, Poulos DA. 1965. Discrimination behavior after amygdalectomy in monkeys: learning set and discrimination reversals. J Comp Physiol Psychol 60(3):320-8.

Sheehan DV, Lecrubier Y, Sheehan KH, Amorim P, Janavs J, Weiller E, Hergueta T, Baker R, Dunbar GC. 1998. The Mini-International Neuropsychiatric Interview (M.I.N.I.): the development and validation of a structured diagnostic psychiatric interview for DSM-IV and ICD-10. J Clin Psychiatry 59 Suppl 20:22-33;quiz 34-57.

Sierra-Mercado D, Jr., Corcoran KA, Lebron-Milad K, Quirk GJ. 2006. Inactivation of the ventromedial prefrontal cortex reduces expression of conditioned fear and impairs subsequent recall of extinction. Eur J Neurosci 24(6):1751-8.

Straube T, Glauer M, Dilger S, Mentzel HJ, Miltner WH. 2006. Effects of cognitive-behavioral therapy on brain activation in specific phobia. Neuroimage 29(1):125-35.

Tzourio-Mazoyer N, Landeau B, Papathanassiou D, Crivello F, Etard O, Delcroix N, Mazoyer B, Joliot M. 2002. Automated anatomical labeling of activations in SPM using a macroscopic anatomical parcellation of the MNI MRI single-subject brain. Neuroimage 15(1):273-89.

Vilensky JA, van Hoesen GW. 1981. Corticopontine projections from the cingulate cortex in the rhesus monkey. Brain Res 205(2):391-5.

Weiskrantz L. 1956. Behavioral changes associated with ablation of the amygdaloid complex in monkeys. J Comp Physiol Psychol 49(4):381-91.

Whalen PJ, Rauch SL, Etcoff NL, McInerney SC, Lee MB, Jenike MA. 1998. Masked presentations of emotional facial expressions modulate amygdala activity without explicit knowledge. J Neurosci 18(1):411-8.

Wright CI, Fischer H, Whalen PJ, McInerney SC, Shin LM, Rauch SL. 2001. Differential prefrontal cortex and amygdala habituation to repeatedly presented emotional stimuli. Neuroreport 12(2):379-83.

Wright CI, Martis B, McMullin K, Shin LM, Rauch SL. 2003. Amygdala and insular responses to emotionally valenced human faces in small animal specific phobia. Biol Psychiatry 54(10):1067-76. 


\section{CHAPTER IV}

\section{Evidence for changes in brain connectivity following single session behavioural therapy}

L. Goossens, S. Sunaert, R. Peeters, E. Griez, K. Schruers Submitted 


\section{Abstract}

Learning experiences in daily life shape our brain. Exposure therapy, an effective treatment in anxiety disorders, can be seen as a behaviourally controlled learning experience. The neurobiological underpinnings of such psychological interventions remain elusive.

We used diffusion tensor imaging to examine the influence of exposure therapy on white matter connections in the brain. Our results indicate that a brief psychological intervention causes alterations in neural pathways. Changes were observed in amygdalofugal fibres following exposure treatment. These fibres form one of the main output pathways of the amygdala by which this structure can directly influence several aspects of emotional behaviour.

Thus, behavioural exposure treatment may bring about its beneficial effect via changes in brain connectivity. 


\section{Introduction}

Experience shapes the brain and the notion of brain plasticity is now well documented.

Voluntarily controlled use of the hand remodels cortical function (Jenkins et al., 1990). Animals exposed to complex environment display an upregulation of neurogenesis in the hippocampus, which in turn improves performance in memory and spatial learning (Brown et al., 2003; Nilsson et al., 1999). And recent evidence in musicians has shown a correlation between the practice of piano playing and the organisation of white matter fibre tracts (Bengtsson et al., 2005).

Exposure treatment, one of the most effective psychological interventions for anxiety disorders, essentially relies on carefully controlled behavioural experiences.

In short, patients are instructed to gradually confront, rather than avoid the fear-eliciting objects or situations. Such therapeutic experiments are known to be followed by metabolic changes in the brain (Baxter et al., 1992; Furmark et al., 2002; Goossens et al., 2007). After behavioural therapy, Baxter et al (Baxter et al., 1992) found decreases in neuronal activity of the caudate nucleus in patients with OCD. Metabolic changes following behavioural therapy of social phobia have been similarly observed (Furmark et al., 2002). It is worth noting that in both cases, changes related to psychological interventions and those induced by effective pharmacotherapy were comparable.

However, structural fibre tract reorganisation, as mentioned above in the case of musicians practicing piano, has never been reported in subjects experiencing behavioural therapy.

Here we document white matter changes following exposure treatment in subjects with an exaggerated fear of spiders, meeting the diagnostic criteria for specific phobia.

\section{Methods}

To examine the changes in brain white matter associated with psychological interventions we collected diffusion tensor imaging (DTI) data from fifteen right-handed female spider phobic subjects without any further psychopathology (mean age: 24.1, SD: 3.3) one week before (mean number of days $=7.9$, range $=6-10$ ) and 2 weeks (mean number of days $=13.4$, range $=10-20$ ) following exposure therapy (Fig 1). The therapy consisted of one 4 to 5 hour intensive sessions (Ost, 1989)in which participants were gradually exposed to spiders. They were confronted with drawings and 
pictures at the start, steadily moving towards the living animal. At the end of the session, all subjects were able to touch a living domestic spider.

The diagnosis of specific phobia was made by an experienced psychiatrist based on DSM-IV criteria. Any further psychopathology was excluded by means of a structured psychiatric interview (Mini International Neuropsychiatric Interview [MINI]) (Sheehan et al., 1998).

In addition, the spider phobia questionnaire [SPQ, (Klorman et al., 1974)] was taken to assess spider fear severity by self-report, as well at the pre as at the post therapy scanning session. Inference about significance of changes in SPQ before and after treatment were assessed using paired ttest $(p<0.05)$.

Written informed consent was obtained from each participant before the experiment. The study was approved by the local ethics committee.

A diffusion weighted single shot spin-echo echoplanar imaging (DTI SE-EPI) sequence (data acquisition matrix: 112x112, field of view (FOV): $220 \times 220$ $\mathrm{mm}$, TR: $12638 \mathrm{~ms}$, TE: $48 \mathrm{~ms}$, parallel imaging factor: 2) with 68 sagital slices (slice thickness: $2.2 \mathrm{~mm}$, voxel size: $1.96 \times 196 \mathrm{~mm}$ ) covering the whole brain was used on a $3 T$ MR scanner. Diffusion gradients were applied along 32 non-collinear directions with a b-value of $800 \mathrm{~s} / \mathrm{mm} 2$, and one set of images without diffusion was acquired. Consequently, a T1-weighted threedimensional turbo field echo scan with $1 \mathrm{~mm}$ isotropic resolution was taken. The DTI-images were post-processed using FSL software (FMRIB Software Library, Release 3, 2004, The university of Oxford) (Smith et al., 2004). Images were corrected for motion and eddy current distortions. The six elements of the diffusion tensor were calculated for each voxel with multivariate linear fitting and fractional anisotropy (FA) maps were generated using FSL-dtifit. The structural T1-images were coregistered affinely to the FA maps (FSL-flirt). The coregistered T1-images were standardized individually onto the MNI T1 template supplied within SPM2 (SPM2, Wellcome Department of Cognitive Neurology, London). The parameter of the normalization was applied to the FA-map for each individual. The normalized FA-maps were smoothed with a 6-mm FWHM isotropic Gaussian kernel.

Statistical significance between pre and post therapy FA-values was tested with a paired t-test in SPM2. The analysis was masked at an FA cut off of 0.2 to reduce partial volume effect from the CSF and gray matter in SPM2. Clusters of thirty voxels or greater surviving a false discovery rate [FDR, (Genovese et al., 2002)] corrected threshold of $p<0.05$ were considered significant. This combination of a level and cluster size was introduced to provide protection against type I error. 


\section{Results}

As shown in fig $1, \mathrm{SPQ}$-scores scores were significantly reduced after therapy (SPQpre: $\left.23.5 \pm 2.9, \mathrm{SPQ}_{\text {post }}: 12.9 \pm 5.9, \mathrm{t}=8.0, \mathrm{P}<0.001\right)$.

Fractional anisotropy (FA) maps were computed from the DTI-data for each subject. This measure is sensitive to developmental changes and pathological differences in axonal density, size, myelination, axonal transport and coherence of organization of fibres within a voxel, and thus provides an index of the structural integrity of white matter \{Basser, 1994 \#497\}. A paired t-test comparison between pre and post exposure FA-maps revealed a significant reduction in FA-value at the white matter junction of the basal ganglia and the amygdala (peak at MNI coordinate [32 -8 -10] mm, 34 voxels, $t=8.39$ ) as displayed in Fig. 2.

The significant cluster was warped to the native DTI space of each subject to extract the mean FA values. A visual inspection controlled that the inversed-normalized cluster was located at the junction of the amygdala and the basal ganglia. A statistically significant reduction in FA-value after therapy was confirmed $(p=0.001)$.

A
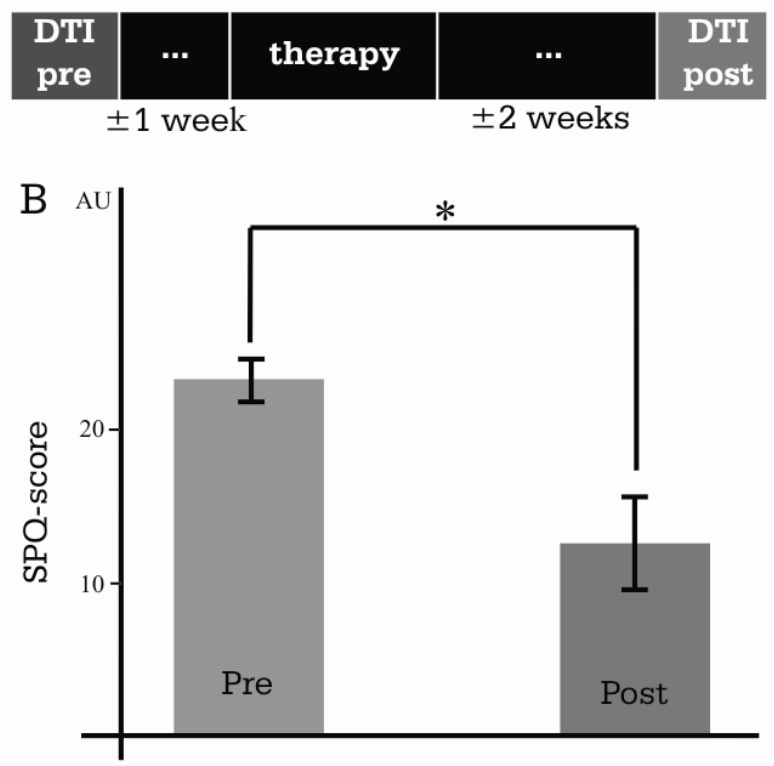

Fig. 1: Significantly reduced SPQ-score after the exposure session.

(A) Study design. (B) Mean SPQ-scores taken at the first scanning session one week before therapy, and at the second scanning session two weeks after therapy. The error bars indicate the standard deviation. (AU: arbitrary units) 


\section{Discussion}

This study demonstrates a reduction in FA values in the white matter surrounding the amygdala, two weeks after a single session of behavioural exposure therapy.

FA values are thought to represent the directionality of freely moving water, imposed by the degree of myelination and the integrity of axons. A reduction in anisotropy can be due to a decreased density of axons, reduced coherence of fibres, or a decrease in myelination (Guo et al., 2002). These are relatively stable properties of brain tissue. At present, it is not clear how a short-term psychological intervention as behavioural exposure therapy can bring about such changes. To our knowledge, this is the first study to show changes in brain connectivity following psychological therapy.

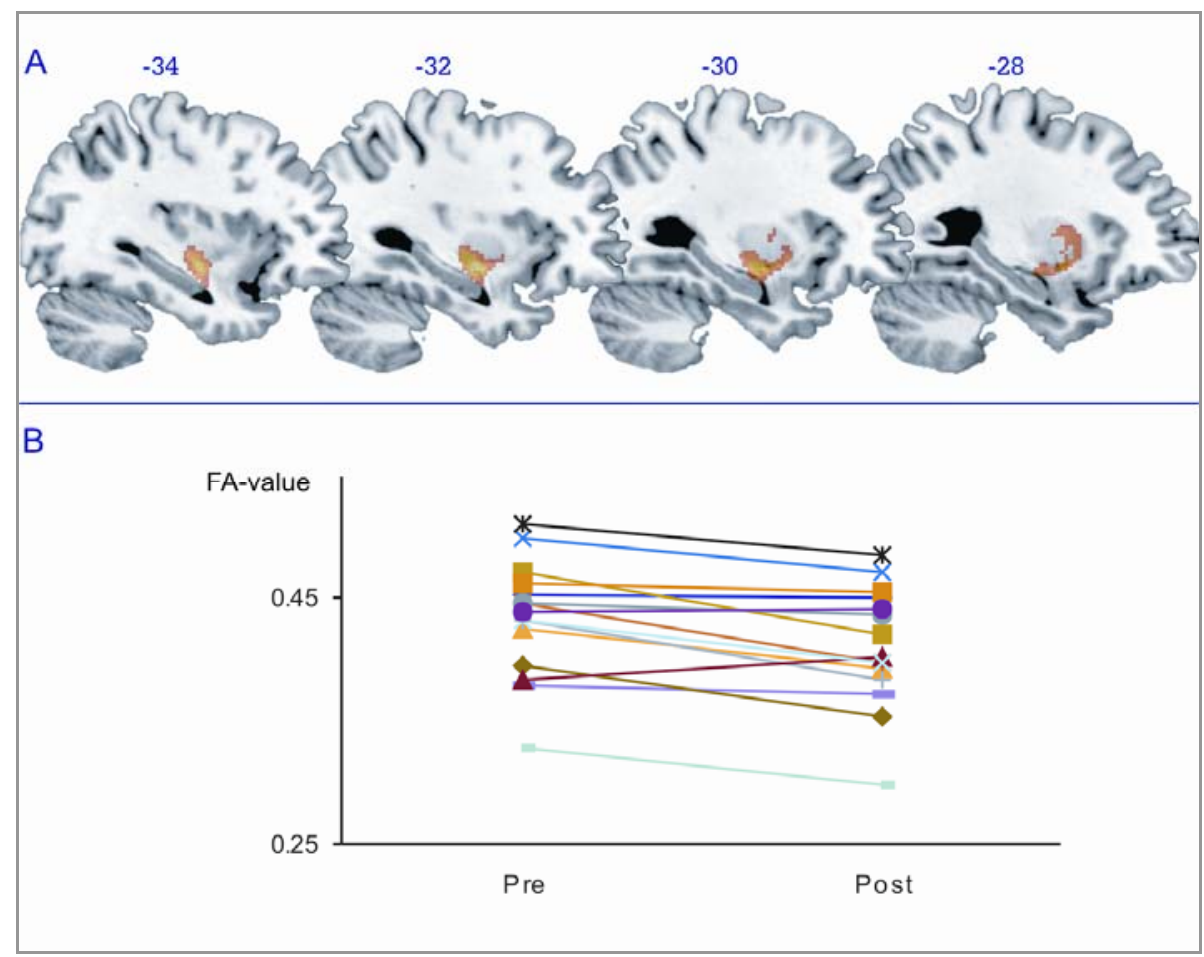

Fig. 2: Reduced FA-values in amygdalofugal fibers.

(A) Statistial parametric maps of the voxel based analysis showing significant reduction in FAvalues on sagital slices. Voxels in green are thresholded at $\mathrm{p}_{\mathrm{FDR}}<0.05$. Voxels in orange are thresholded at $p_{\text {uncorrected }}<0.001$. (B) The reduction in mean FA-value for the significant cluster for each individual is displayed in the graph. 
It has been proven that the brain is remarkably responsive to its interactions with the environment. Past research has revealed that changes associated with learning are stable and longstanding. These brain alterations consist of changes in synapse number and morphology, and responses of oligodendrocytes and axonal myelination (Markham and Greenough, 2004), which in turn could contribute to alterations in FA-value.

Noteworthy, our data shows changes in FA to be localized in amygdalofugal fibres connecting the amygdala and the basal ganglia. Both these structures are implicated in emotional learning and memory (Davis and Whalen, 2001; Graybiel, 1995) and in governing instinctive action patterns (Berridge et al., 2005; Graybiel, 1995).

Fear reactions observed in phobic individuals when confronted with their dreaded object are a form of such an instinctive action pattern The response includes sympathetic activations, a significant potentiation of the startle reflex and the urge to flee. This type of behaviour is dependent on amygdala and basal ganglia function. Especially connections from the basal amygdala to the striatum are involved in controlling actions like flight (LeDoux, 2007).

Psychological therapies involve a form of emotional learning. It has been shown that existing pathological associations are not removed, but are rather superseded by learning of new associations, leading to changes in emotional non declarative memory (Bouton, 2004).. The amygdala has a central role in emotional learning and more specifically in forming an association between a previously neutral stimulus and aversive outcome (for review see (Davis and Whalen, 2001; LeDoux, 2000). Learning of the concomitant non-conscious skills or habits is supported by the basal ganglia (Butler et al., 2007). Both new associations and action patterns are consequently stored, leading to changes in memory.

Learning and subsequent memory can function explicitly or implicitly. Explicit learning gives rise to conscious and declarative memory, while implicit learning involves automatic processes that lead to procedural memory of non-conscious skills or habits. Studies have identified separate systems underlying these functions. The former involves the hippocampus, while the latter, subserving habit memory, is dependent on the basal ganglia (Cohen and Eichenbaum, 1993; Squire, 1992). Habit memory, as seen in phobia, is thought to be a phylogenetically older kind of memory (Broadbent et al., 2007).

The amygdala can modulate memory processes in other brain structures, including the basal ganglia. From animal studies it appears that the amygdala mediates the influence of drugs on memory consolidation (McGaugh, 2002). Data from the present study suggest that the amygdala also mediates the effects of psychological therapy on basal ganglia function. 
The area of reduced FA values coincides with the location of ventral amygdalofugal fibres that carry signals from the amygdala to ventral parts of the basal ganglia. This suggests that the found reduction may represent a change in the modulatory influence of the amygdala on the basal ganglia, responsible for the reduced fear reaction towards spiders.

The present study offers insight into the neural mechanisms of psychological therapy. It complements the findings of functional imaging studies by pointing to the importance of connections between brain structures. Further DTI-fMRI studies should explore whether the effects are long-lasting, and whether they can be extended to other types of psychopathology. 


\section{References}

Baxter LR, Jr., Schwartz JM, Bergman KS, Szuba MP, Guze BH, Mazziotta JC, Alazraki A, Selin $\mathrm{CE}$, Ferng HK, Munford $\mathrm{P}$ and others. 1992. Caudate glucose metabolic rate changes with both drug and behavior therapy for obsessive-compulsive disorder. Arch Gen Psychiatry 49(9):681-9.

Bengtsson SL, Nagy Z, Skare S, Forsman L, Forssberg H, Ullen F. 2005. Extensive piano practicing has regionally specific effects on white matter development. Nat Neurosci 8(9):1148-50.

Berridge KC, Aldridge JW, Houchard KR, Zhuang X. 2005. Sequential super-stereotypy of an instinctive fixed action pattern in hyper-dopaminergic mutant mice: a model of obsessive compulsive disorder and Tourette's. BMC Biol 3:4.

Bouton ME. 2004. Context and behavioral processes in extinction. Learn Mem 11(5):485-94.

Broadbent NJ, Squire LR, Clark RE. 2007. Rats depend on habit memory for discrimination learning and retention. Learn Mem 14(3):145-51.

Brown J, Cooper-Kuhn CM, Kempermann G, Van Praag H, Winkler J, Gage FH, Kuhn HG. 2003. Enriched environment and physical activity stimulate hippocampal but not olfactory bulb neurogenesis. Eur J Neurosci 17(10):2042-6.

Butler T, Pan H, Tuescher O, Engelien A, Goldstein M, Epstein J, Weisholtz D, Root JC, Protopopescu X, Cunningham-Bussel AC and others. 2007. Human fear-related motor neurocircuitry. Neuroscience 150(1):1-7.

Cohen N, Eichenbaum H. 1993. Memory, amnesia, and the hippocampal system. Cambridge (MA): MIT Press.

Davis M, Whalen PJ. 2001. The amygdala: vigilance and emotion. Mol Psychiatry 6(1):13-34.

Furmark T, Tillfors M, Marteinsdottir I, Fischer H, Pissiota A, Langstrom B, Fredrikson M. 2002. Common changes in cerebral blood flow in patients with social phobia treated with citalopram or cognitive-behavioral therapy. Arch Gen Psychiatry 59(5):425-33.

Genovese CR, Lazar NA, Nichols T. 2002. Thresholding of statistical maps in functional neuroimaging using the false discovery rate. Neuroimage 15(4):870-8.

Goossens L, Sunaert S, Peeters R, Griez EJ, Schruers KR. 2007. Amygdala hyperfunction in phobic fear normalizes after exposure. Biol Psychiatry 62(10):1119-25.

Graybiel AM. 1995. Building action repertoires: memory and learning functions of the basal ganglia. Curr Opin Neurobiol 5(6):733-41.

Guo AC, MacFall JR, Provenzale JM. 2002. Multiple sclerosis: diffusion tensor MR imaging for evaluation of normal-appearing white matter. Radiology 222(3):729-36.

Jenkins WM, Merzenich MM, Ochs MT, Allard T, Guic-Robles E. 1990. Functional reorganization of primary somatosensory cortex in adult owl monkeys after behaviorally controlled tactile stimulation. J Neurophysiol 63(1):82-104.

Klorman R, Weerts TC, Hastings JE, Melamed BG, Lang PJ. 1974. Psychometric description of some specific-fear questionnaires. Behavior therapy 5:401-409.

LeDoux J. 2007. The amygdala. Current Biology 17(20):R868-R874.

LeDoux JE. 2000. Emotion circuits in the brain. Annu Rev Neurosci 23:155-84.

Markham JA, Greenough WT. 2004. Experience-driven brain plasticity: beyond the synapse. Neuron Glia Biol 1(4):351-363.

McGaugh JL. 2002. Memory consolidation and the amygdala: a systems perspective. Trends Neurosci 25(9):456.

Nilsson M, Perfilieva E, Johansson U, Orwar O, Eriksson PS. 1999. Enriched environment increases neurogenesis in the adult rat dentate gyrus and improves spatial memory. J Neurobiol 39(4):569-78.

Ost LG. 1989. One-session treatment for specific phobias. Behav Res Ther 27(1):1-7.

Sheehan DV, Lecrubier Y, Sheehan KH, Amorim P, Janavs J, Weiller E, Hergueta T, Baker R, Dunbar GC. 1998. The Mini-International Neuropsychiatric Interview (M.I.N.I.): the development and validation of a structured diagnostic psychiatric interview for DSM-IV and ICD-10. J Clin Psychiatry 59 Suppl 20:22-33;quiz 34-57. 
White Matter Changes following Behavioural Therapy

Smith SM, Jenkinson M, Woolrich MW, Beckmann CF, Behrens TE, Johansen-Berg H, Bannister PR, De Luca M, Drobnjak I, Flitney DE and others. 2004. Advances in functional and structural MR image analysis and implementation as FSL. Neuroimage 23 Suppl 1:S20819.

Squire LR. 1992. Memory and the hippocampus: a synthesis from findings with rats, monkeys, and humans. Psychol Rev 99(2):195-231. 


\section{CHAPTER V}

\section{Selective processing of social stimuli in the superficial amygdala}

L. Goossens, J. Kukolja, O.A. Onur, G.R. Fink, W. Maier, E.J.L. Griez, K.R. Schruers, R. Hurlemann

Human Brain Mapping (2009) 


\section{Abstract}

The human amygdala plays a pivotal role in the processing of socially significant information. Anatomical studies show that the human amygdala is not a single homogeneous structure but is composed of segregable subregions. These have recently been functionally delineated by using the combination of functional magnetic resonance imaging (fMRI) and cytoarchitectonically defined probabilistic maps. However, the response characteristics and individual contribution of these subregions to the processing of social-emotional stimuli are little understood. Here, we used this novel technique to segregate intra-amygdalar responses to facial expressions and nonsocial control stimuli. We localized facial expressionevoked signal changes bilaterally in the superficial amygdala, suggesting that this subregion selectively extracts the social value of incoming sensory information. 


\section{Introduction}

Human facial expressions serve a critical communicatory role in guiding social interactions (Blair, 2003) and in mediating the social transmission of emotion (Olsson and Phelps, 2007). The biological importance of socialemotional communication via facial expressions is supported by evidence from cross-cultural studies demonstrating a cultural invariance in face recognition (Izard, 1994) and from affective neuroscience, which has revealed dedicated neural substrates for face perception, with electrophysiological, lesion, and functional imaging evidence converging on a central role of the amygdaloid complex (henceforth referred to as the amygdala) (Adolphs and Spezio, 2006).

The amygdala has been conceptualized as a 'relevance detector' (Sander et al., 2003), primarily responding to environmental stimuli which are of central importance to the organism and its survival. A recent quantitative metaanalysis of the role of the amygdala in social-emotional processing documented more robust amygdala responses to faces compared to other types of pictorial stimuli (Hariri et al., 2002; Sergerie et al., 2008). Moreover, faces show an enhanced pop-out in a visual dynamic environment, an effect mediated by the amygdala (Reinders et al., 2005). Even in nonhuman primates, neuronal recording studies have identified face-sensitive neurons in the amygdala (Gothard et al., 2007; Leonard et al., 1985).

Like most brain regions, the amygdala is not a single homogenous structure but is composed of distinct subareas or nuclei (LeDoux, 2007). These nuclei differ cytoarchitectonically, chemoarchitectonally, and in their connectivity (Pitkanen, 2000). In addition, it has been proposed that the amygdala consists of phylogenetically older and newer subdivisions (Johnston, 1923; Laberge et al., 2006). Consequently, the amygdala can be regarded as neither an anatomical nor a functional unit (Swanson and Petrovich, 1998). For a better understanding of amygdala functions, it is crucial to determine the individual contribution of distinct amygdala subareas to social-emotional information processing. However, data on the intrinsic functional architecture of the amygdala are mainly derived from studies in animals (LeDoux, 2007) . Due to current limits in spatial resolution of standard MRI protocols, it is not possible to functionally dissociate human amygdala nuclei in vivo. However, on the basis of microscopic cytoarchitectonic parcellations in ten human postmortem brains, probabilistic maps of the human amygdala and its major subregions have been developed and warped to a common reference brain (Amunts et al., 2005). These maps distinguish the superficial subregion from the centromedial and laterobasal subregions (Heimer et al., 1999) and take into account the stereotaxic position of these subregions as well as intersubject variability. Recently, proof of concept studies combined cytoarchitectonic probabilistic maps of the human amygdala and functional 
magnetic resonance imaging (FMRI) to investigate intra-amygdalar response characteristics (Ball et al., 2007; Hurlemann et al., 2008; Kukolja et al., 2008). Given this background, the aim of the present study was to disentangle intra-amygdalar responses to different facial expressions and nonsocial control stimuli by using fMRI in combination with cytoarchitectonic probability maps as regions of interest (ROIs).

\section{Methods}

\section{Subjects}

Twenty healthy, right-handed adults (10 females; mean age, 26 years old; age range 20-32 years old) volunteered and were paid for their participation. All subjects gave written, informed consent in accordance with the latest revision of the 1964 Declaration of Helsinki. Subjects were screened for MR compatibility as well as neurological and medical illness. Any psychopathology was excluded using a structured psychiatric interview (Sheehan et al., 1998) assessed by an experienced clinician (J.K.). The study had full ethics approval.

\section{Stimulus design and presentation}

Stimuli consisted of photographs depicting 40 individuals showing three kinds of emotional expressions: neutral, fearful and happy. The faces were taken from the validated Karolinska Directed Emotional Face database (Goeleven et al., 2008). Photographs of houses [taken from (Reinders et al., 2005)] were used as non-facial control stimuli. Houses can be used as control stimuli for faces because they share similar spatial and visual features (Vuilleumier et al., 2001; Wojciulik et al., 1998; Yovel and Kanwisher, 2004) In addition, houses are static non-arousing everyday objects which are familiar to all subjects. All stimuli were grey-scaled, and equated for size and luminance.

Using Presentation11 (Neurobehavioral Systems, Inc., Albany, CA, USA), the stimuli were presented in a block-wise fashion on a TFT screen behind the MRI scanner via a mirror system (viewing distance approx. $254 \mathrm{~cm}$ ). Blocks consisted of four different stimuli of the same kind (neutral, fearful or happy faces, or houses). Stimuli were presented for $2625 \mathrm{~ms}$, with a variable interstimulus interval ranging between $250 \mathrm{~ms}$ and $1500 \mathrm{~ms}$, amounting to a block length of $14.5 \mathrm{sec}$. The sequence of house and face blocks was randomized. Blocks were separated by a baseline condition (lasting $14.5 \mathrm{sec}$ ) showing a white fixation cross in the center of a black screen. Subjects were asked to look attentively at the stimuli. A button press whenever a new stimulus occurred was recorded to assure proper stimulus processing. The variable interstimulus interval assured the non-predictability of stimulus 
occurrence. After scanning, participants were asked to rate all stimuli on a 9point scale for emotional arousal (ranging from 0 - not arousing - to 9 most arousing) and valence (ranging from 0 - most unpleasant - to 9 most pleasant).

\section{fMRI acquisition}

Brain images were acquired using a TRIO 3T scanner (Siemens Medical Solutions, Erlangen, Germany) equipped with a standard head coil for radiofrequency transmission and signal reception. T2*-weighted echoplanar images (EPI) with blood-oxygenation level-dependent (BOLD) contrast, echo time $(T E)=31 \mathrm{~ms}$, repetition time $(T R)=2000 \mathrm{~ms}$, flip angle $=90^{\circ}$, slice thickness $2.0 \mathrm{~mm}$, interslice gap $1.0 \mathrm{~mm}$, field of view (FoV) $=200 \mathrm{~mm}$, matrix size $88 \times 88$, in-plane resolution $=2.273 \mathrm{~mm} \times 2.273 \mathrm{~mm}$. Twentyeight axial slices per volume were positioned at an angle between the line crossing the anterior and posterior commissure (AC-PC line) and a line paralleling the medial tentorium cerebelli in order to reduce susceptibility artefacts. In addition, a high-resolution T1 anatomical image was obtained for each subject using a standard 3D MP-RAGE sequence.

\section{fMRI data analysis}

Spatial pre-processing and statistical analysis of the functional MR data were performed using Matlab7 (The MathWorks Inc., Natick, MA, USA) and SPM5 (http://www.fil.ion.ucl.ac.uk/spm). The EPI images were spatially realigned to the first image in the series to correct for head movements. Five dummy images at the beginning of each time series were discarded from further analysis. After co-registering the functional images to the anatomical image, they were spatially normalized to the MNI single subject template provided by SPM5. All functional images were sub-sampled to a voxel size of $2 \times 2 \times$ $2 \mathrm{~mm} 3$ and smoothed with a Gaussian kernel of $4 \mathrm{~mm}$ full width at half maximum (FWHM). First level statistical analysis was done for all subjects in the context of the general linear model (GLM). Each of the experimental condition (fearful, happy, neutral, house) was modeled by a boxcar function convolved with a hemodynamic response function and its temporal derivative. Baseline contrasts for the four conditions were entered into a second level $4 \times 1$ ANOVA analysis. The present study sought to segregate responses of the different amygdala subregions to facial expressions compared to house stimuli, and the specific influences of positive and negative facial emotion. Hence, pair-wise t-statistics were calculated for the events of interest: i.e., Faces > Houses; (happy + fear) > neutral; fear > neutral; happy > neutral. The 'anatomy toolbox' (Eickhoff et al., 2006; Eickhoff et al., 2005) was used to generate a ROI for the amygdala bilaterally by use of cytoarchitectonic probability maps. These maps denote the most likely anatomical area at each voxel of the MNI single subject 
template based on probabilistic cytoarchitectonic maps derived from a sample of 10 human post-mortem brains. The amygdala ROIs used in the present study covered the centromedial (CM, including the central and medial nuclei), superficial (SF, including the anterior amygdala area, ventral, and posterior cortical nuclei) (Fig. 1), and laterobasal groups (LB, including the lateral, basolateral, basomedial, and paralaminar nuclei) of nuclei [Amunts et al., 2005]. Activations are reported at a significance level of $p<$ .05 , family-wise error corrected, and an extent threshold of $k>3$ voxels. Voxels coordinates are expressed in MNI (Montreal Neurological Institute)space. For every cluster, the 'anatomy toolbox' returns the relative contribution of voxels located within specific amygdala subregions quantified in percentage $(\%)$.

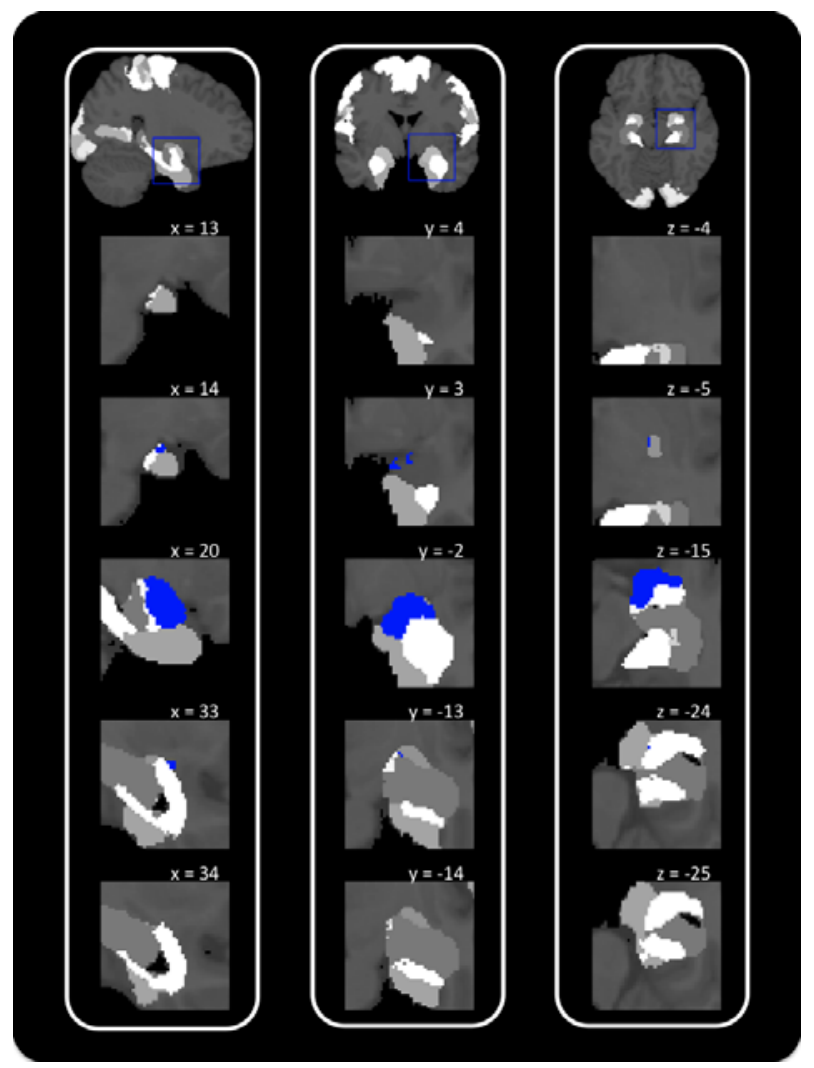

Fig. 1: Presented are sections through the cytoarchitectonic probability map of the superficial subregion of the amygdala (blue) in anatomical MNI (Montreal Neurological Institute) space (xyz-coordinates indicate distances from the anterior commissure in $\mathrm{mm}$ in the mediolateral, rostrocaudal and dorsoventral directions, respectively) [Amunts et al., 2005; Eickhoff et al., 2006; Eickhoff et al., 2005]. The first column (sagittal sections) lists the x-coordinates, the second column (coronal sections) the y-coordinates, and the third column (horizontal sections) the $z$-coordinates of the smallest (borders) and largest areas covered by the map. 


\section{Results}

\section{Behavioral data}

Emotional arousal and valence ratings are listed in Table 1. A repeated measures ANOVA revealed a main effect of stimulus type (i.e., fear, happy, neutral, and house stimuli) for both dimensions (Arousal: $F[3,10]=28.7, p$ $<.001$; valence: $\mathrm{F}[3,10]=26.7, \mathrm{p}<.001$ ). Posthoc bonferroni-corrected testing showed no difference in arousal ratings between fearful and happy faces. They were rated as more arousing than neutral faces $(p<.001)$ and pictures of houses $(p<.001)$. Neutral faces were more arousing then houses $(p<.002)$. Neutral faces and houses were not rated differently on the valence scale. As expected, happy faces were perceived more pleasant than neutral faces and houses $(p<.001)$, while fearful faces evoked a more negative valence rating $(p<.001)$.

Table I. Behavioural ratings

\begin{tabular}{|c|c|c|c|c|c|c|c|c|}
\hline & \multicolumn{2}{|c|}{ Fear } & \multicolumn{2}{|c|}{ Happy } & \multicolumn{2}{|c|}{ Neutral } & \multicolumn{2}{|c|}{ House } \\
\hline & mean & (SEM) & mean & (SEM) & mean & (SEM) & mean & (SEM) \\
\hline arousal & 4.97 & $(0.45)$ & 4.80 & $(0.52)$ & 2.71 & $(0.24)$ & 1.67 & $(0.32)$ \\
\hline valence & 2.74 & $(0.20)$ & 5.69 & $(0.44)$ & 3.86 & $(0.27)$ & 4.18 & $(0.35)$ \\
\hline
\end{tabular}

\section{I maging data}

The ROI analysis with the probability maps for the main contrast of interest 'faces > houses' revealed significant clusters bilaterally in the amygdala. The first cluster contained 11 voxels and was $100 \%$ situated in the right superficial amygdala (local maximum: $x=22, y=-2, z=-15$ ). A second cluster containing eight voxels (local maximum: $x=-18, y=-2, z=-19$ ) in the left amygdala was allocated to the superficial subregion as well (Fig. 2). The reverse contrast (houses $>$ faces) yielded no significant results. The ROI analysis comparing the emotional faces with the neutral faces did not show significantly activated voxels in the amygdala (Fig. 3). Moreover, there was no difference in activation between the emotional faces. 


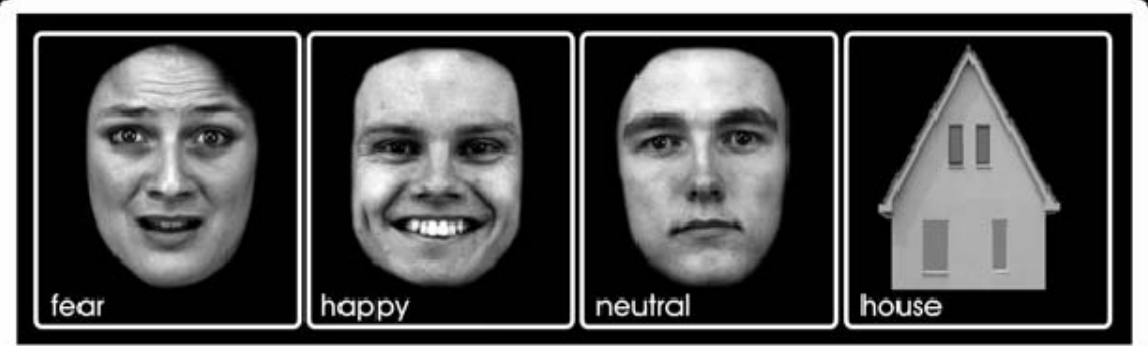

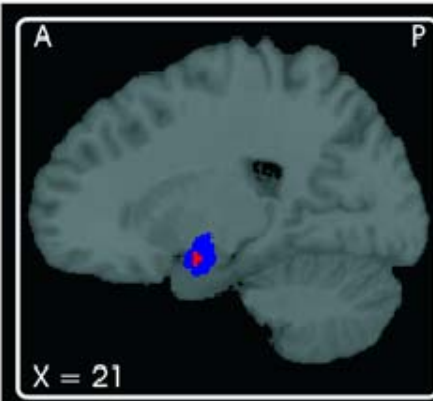

$\square$ superficial amygdala

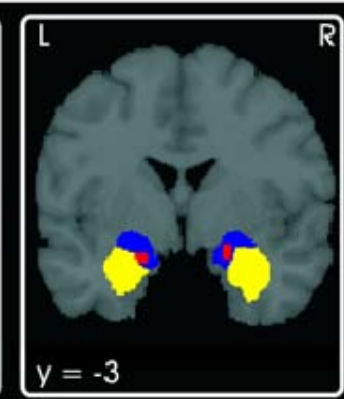

laterobasal amygdala

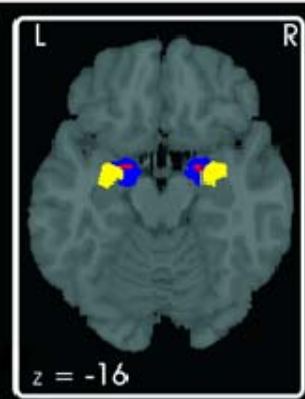

significant clusters

Fig. 2: The top panel displays examples of the face (fear, happy, and neutral) and house stimuli used in this study. The bottom panel shows a sagittal, a coronal, and a transversal activation map with significantly more robust blood-oxygenation level-dependent BOLD signal for faces than houses in the superficial subregion of the amygdala

\section{Discussion}

This fMRI study is the first to demonstrate the specific involvement of the superficial amygdala in the processing of facial expressions versus house stimuli. Superficial amygdala responses to fearful, happy, and neutral facial expressions did not significantly differ from each other, suggesting that this subregion selectively extracts the social value of incoming stimuli.

Electrophysiological, lesion, and functional imaging studies converge on a key role of the amygdala in social-emotional information processing. The intrinsic functional organization of amygdala nuclei in humans, however, until present has remained unclear. In primates, face-selective amygdalar neurons have been located in the basolateral complex (Gothard et al., 2007; Hoffman et al., 2007; Kuraoka and Nakamura, 2007). Although this seems in contrast with our results, one has to take into consideration that the neuronal recordings were often placed in the centromedial and basolateral subareas of the amygdala, motivated, to a large extent, by studies in rodents, which have identified these subareas as key anatomical substrates 
of emotional learning (LeDoux, 2007). The basolateral amygdala appears to be the main input terminal for information ascending from unimodal sensory and polysensory cortices, and therefore in an ideal strategic position for emotional learning (Amaral et al., 1992; LeDoux, 2007). Processed information is then channeled to the centromedial amygdala, which constitutes the main output centre for the appropriate behavioral response (LeDoux, 2007).

Studies of the functional architecture of the human amygdala are scarce due to the technical limitations mentioned before. The cytoarchitectonic probabilistic mapping technique, although perhaps not as precise as neuronal recordings in animals, offers an elegant solution in humans. Ball et al. (Ball et al., 2007) used cytoarchitectonic probabilistic maps in order to analyze intra-amygdalar responses to auditory stimuli. Amygdala activations to pleasant and unpleasant melodies were mainly located in the laterobasal subregion. More closely related to the present study, Hurlemann et al. (Hurlemann et al., 2008) used virtual facial emotion stimuli to investigate intra-amygdalar response characteristics. The ROI analysis resulted in significant activation clusters mainly located in the superficial amygdala. Kukolja et al. (Kukolja et al., 2008) demonstrated that pharmacological enhancement of the stress-related neuromodulators noradrenaline and cortisol induces a negative response bias of the superficial amygdala, which does not exist at placebo baseline.

In lower nonprimate animals, the superficial amygdala (including the olfactorial and vomeronasal amygdala) has been functionally linked with intraspecies communication via olfactory stimuli (Moreno and Gonzalez, 2007). In primates, successful social interactions also depend on subtle visual information, including rapid information transfer amonst conspecifics via facial expressions. It might therefore be reasonable to hypothesize that throughout phylogeny there has been an expansion of superficial amygdala function in relation to the increasing complexity of social behavior. Further insights into the functional role of the superficial subregion may result from ontogenetic and phylogenetic studies. Amygdala nuclei stem from different embryological origin. According to studies in the early 20th century, the centromedial and superficial amygdala have developed from the subpallium, whereas the basolateral amygdala has its origin in the pallial primordium (Holmgren, 1925; Källén, 1951). However, recent histogenetic studies assign the superficial amygdala to the pallial amygdala (Puelles et al., 2000; Puelles and Rubenstein, 2002). Phylogenetically, this basic organization seems to hold for tetrapods in general, although the nonmammalian amniotes and the anurans do not share all anatomical characteristics that have been reported for mammals. The central amygdala and the superficial amygdala (including the olfactorial and vomeronasal amygdala) thus seem to be the most 
conserved amygdala subareas throughout evolution (Moreno and Gonzalez, 2007). The preservation of these subareas might again point to a critical role in social communication. Furthermore, both the superficial and basolateral amygdala show strong tendencies of enlargement in an ascending primate scale (Stephan and Andy, 1977), which we speculate might also be related to the evolution of complex social behavior.

Our findings reveal no difference in intra-amygdalar responses to fearful, happy, and neutral faces. This is consistent with the current turn in the literature that the amygdala not only responds to social signals of threat, as previously thought, but has a broader role in processing stimulus relevance (Sander et al., 2003). Specifically, recent fMRI studies showed similar amygdala activations in response to fearful, angry, disgusted, sad, happy, and neutral facial expressions, which argues against a selective role of the amygdala as a threat module (Fitzgerald et al., 2006; van der Gaag et al., 2007).

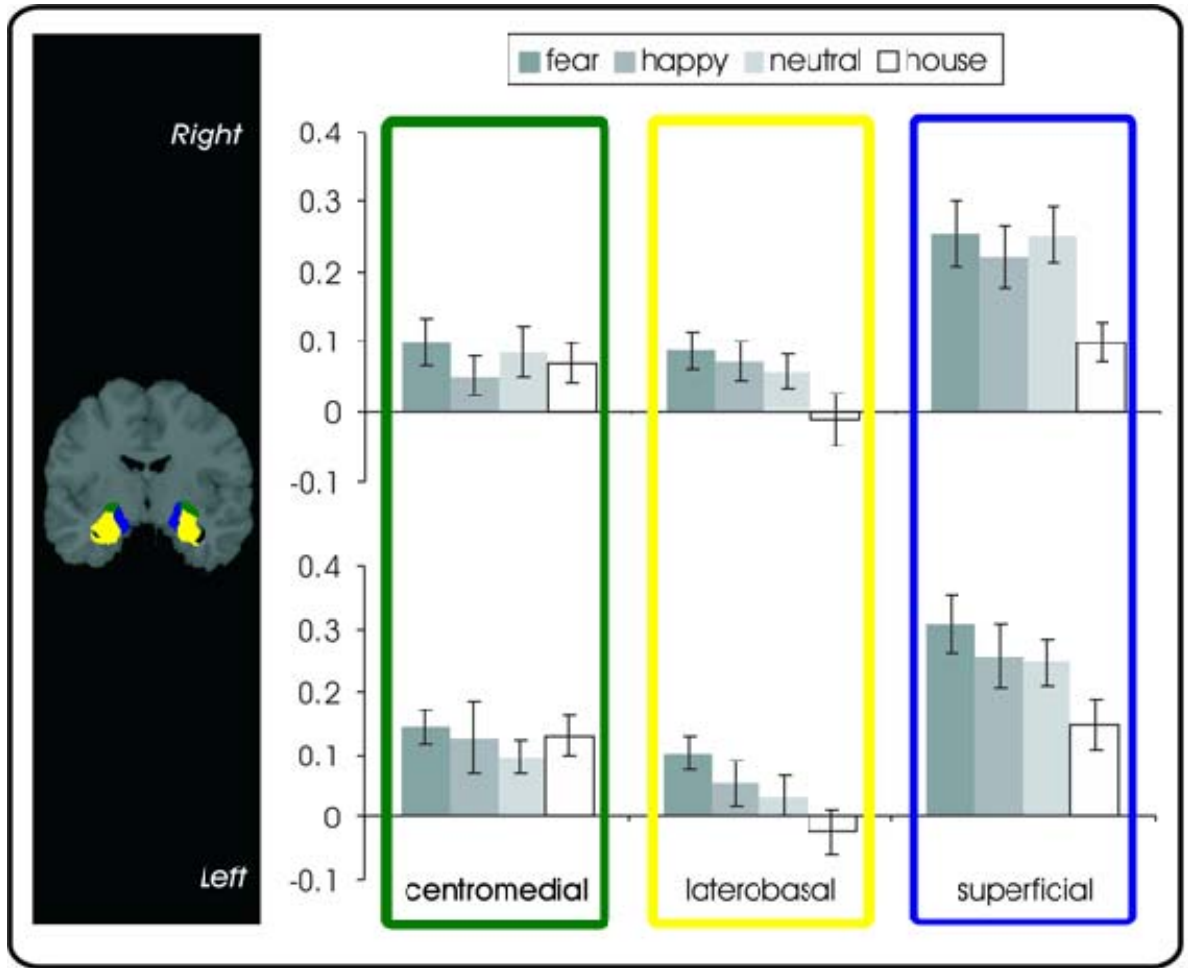

Fig. 3: The coronal slice on the left shows the centromedial (green), the laterobasal (yellow), and the superficial (blue) subregions of the amygdala. The graphs display the mean percentage of signal increase for every condition in each subregion of the amygdala (SEM error bars). 
In conclusion, our results demonstrate that social stimuli, but not nonsocial control stimuli, evoke robust responses of the superficial subregion of the amygdala. It thus appears that this evolutionary well preserved amygdala subregion is a first stage station in the extraction of social value from incoming sensory information. One might extend this interpretation to the superficial amygdala being critically involved in identifying environmental stimuli with an inherent significance for social communication, which is one of the major forces driving human evolution (Humphrey, 1976). 


\section{References}

Adolphs R, Spezio M. 2006. Role of the amygdala in processing visual social stimuli

Progress in Brain Research. In: S. Anders GE, M. Junghofer, J. Kissler and D. Wildgruber, editor. Understanding Emotions. Volume 156 ed: Elsevier. p 363-378.

Amaral DG, Price JL, Pitkanen A, Carmichael ST. 1992. Anatomical organization of the primate amygdaloid complex. In: Aggleton JP, editor. The amygdala: Neurobiological aspects of emotion, memory, and mental dysfunction. New York: Wiley-Liss. p 1-66.

Amunts K, Kedo O, Kindler M, Pieperhoff $\mathrm{P}$, Mohlberg $\mathrm{H}$, Shah NJ, Habel U, Schneider F, Zilles K. 2005. Cytoarchitectonic mapping of the human amygdala, hippocampal region and entorhinal cortex: intersubject variability and probability maps. Anat Embryol (Berl) 210(5-6):343-52.

Ball T, Rahm B, Eickhoff SB, Schulze-Bonhage A, Speck O, Mutschler I. 2007. Response properties of human amygdala subregions: evidence based on functional MRI combined with probabilistic anatomical maps. PLoS ONE 2(3):e307.

Blair RJ. 2003. Facial expressions, their communicatory functions and neuro-cognitive substrates. Philos Trans R Soc Lond B Biol Sci 358(1431):561-72.

Eickhoff SB, Heim S, Zilles K, Amunts K. 2006. Testing anatomically specified hypotheses in functional imaging using cytoarchitectonic maps. Neuroimage 32(2):570-82.

Eickhoff SB, Stephan KE, Mohlberg H, Grefkes C, Fink GR, Amunts K, Zilles K. 2005. A new SPM toolbox for combining probabilistic cytoarchitectonic maps and functional imaging data. Neuroimage 25(4):1325-35.

Fitzgerald DA, Angstadt M, Jelsone LM, Nathan PJ, Phan KL. 2006. Beyond threat: Amygdala reactivity across multiple expressions of facial affect. NeuroImage 30(4):1441-1448.

Goeleven E, De Raedt R, Leyman L, Verschuere B. 2008. The Karolinska directed emotional faces: a validation study. Cogn Emot 22(6):1094-1118.

Gothard KM, Battaglia FP, Erickson CA, Spitler KM, Amaral DG. 2007. Neural responses to facial expression and face identity in the monkey amygdala. J Neurophysiol 97(2):1671-83.

Hariri AR, Tessitore A, Mattay VS, Fera F, Weinberger DR. 2002. The amygdala response to emotional stimuli: a comparison of faces and scenes. Neuroimage 17(1):317-23.

Heimer L, de Olmos JS, Alheid GF, Pearson J, Sakamoto N, Shinoda K, Marksteiner J, Switzer RC. 1999. The human basal forebrain, part 2. The primate Nervous system, part 3. In: Bloom FE, Björklund A, Hökfelt T, editors. Handbook of Chemical Neuroanatomy. Amsterdam: Elsevier. p 57-226.

Hoffman KL, Gothard KM, Schmid MC, Logothetis NK. 2007. Facial-Expression and GazeSelective Responses in the Monkey Amygdala. Current Biology 17(9):766-772.

Holmgren N. 1925. Points of view concerning forebrain morphology in higher vertebrates. Acta Zool 6:413-477.

Humphrey NK. 1976. The social function of intellect. In: Bateson PPG, Hinde RA, editors. Growing Points in Ethology. Cambridge: Cambridge University Press. p 303-317.

Hurlemann R, Rehme AK, Diessel M, Kukolja J, Maier W, Walter H, Cohen MX. 2008. Segregating intra-amygdalar responses to dynamic facial emotion with cytoarchitectonic maximum probability maps. J Neurosci Methods 172(1):13-20.

Izard CE. 1994. Innate and universal facial expressions: evidence from developmental and cross-cultural research. Psychol Bull 115(2):288-99.

Johnston J. 1923. Further contributions to the study of the evolution of the forebrain. J Comp Neurol 35:337-481.

Källén B. 1951. The nuclear devlopment of in the mammalian forebrain with special regard to the forebrain. Kgl Fysiogr Sällsk Lund Handl N F 61:1-43.

Kukolja J, Schlapfer TE, Keysers C, Klingmuller D, Maier W, Fink GR, Hurlemann R. 2008. Modeling a negative response bias in the human amygdala by noradrenergicglucocorticoid interactions. J Neurosci 28(48):12868-76.

Kuraoka K, Nakamura K. 2007. Responses of single neurons in monkey amygdala to facial and vocal emotions. J Neurophysiol 97(2):1379-87. 
Laberge F, Muhlenbrock-Lenter S, Grunwald W, Roth G. 2006. Evolution of the amygdala: new insights from studies in amphibians. Brain Behav Evol 67(4):177-87.

LeDoux J. 2007. The amygdala. Current Biology 17(20):R868-R874.

Leonard CM, Rolls ET, Wilson FA, Baylis GC. 1985. Neurons in the amygdala of the monkey with responses selective for faces. Behav Brain Res 15(2):159-76.

Moreno N, Gonzalez A. 2007. Evolution of the amygdaloid complex in vertebrates, with special reference to the anamnio-amniotic transition. J Anat 211(2):151-63.

Olsson A, Phelps EA. 2007. Social learning of fear. Nat Neurosci 10(9):1095-102.

Pitkanen A. 2000. Connectivity of the rat amygdaloid complex. In: Aggleton JP, editor. The amygdala: a functional analysis. New York: Oxford University Press. p 31-103.

Puelles L, Kuwana E, Puelles E, Bulfone A, Shimamura K, Keleher J, Smiga S, Rubenstein JL. 2000. Pallial and subpallial derivatives in the embryonic chick and mouse telencephalon, traced by the expression of the genes Dlx-2, Emx-1, Nkx-2.1, Pax-6, and Tbr-1. J Comp Neurol 424(3):409-38.

Puelles L, Rubenstein JLR. 2002. Forebrain. In: Ramachandran VS, editor. Encyclopedia of the human brain. Amsterdam: Academic Press. p 299-315.

Reinders AA, den Boer JA, Buchel C. 2005. The robustness of perception. Eur J Neurosci 22(2):524-30.

Sander D, Grafman J, Zalla T. 2003. The human amygdala: an evolved system for relevance detection. Rev Neurosci 14(4):303-16.

Sergerie K, Chochol C, Armony JL. 2008. The role of the amygdala in emotional processing: a quantitative meta-analysis of functional neuroimaging studies. Neurosci Biobehav Rev 32(4):811-30.

Sheehan DV, Lecrubier $\mathrm{Y}$, Sheehan KH, Amorim P, Janavs J, Weiller E, Hergueta T, Baker R, Dunbar GC. 1998. The Mini-International Neuropsychiatric Interview (M.I.N.I.): the development and validation of a structured diagnostic psychiatric interview for DSM-IV and ICD-10. J Clin Psychiatry 59 Suppl 20:22-33;quiz 34-57.

Stephan H, Andy OJ. 1977. Quantitative comparison of the amygdala in insectivores and primates. Acta Anat (Basel) 98(2):130-53.

Swanson LW, Petrovich GD. 1998. What is the amygdala? Trends Neurosci 21(8):323-31.

van der Gaag C, Minderaa RB, Keysers C. 2007. The BOLD signal in the amygdala does not differentiate between dynamic facial expressions. Soc Cogn Affect Neurosci 2(2):93-103.

Vuilleumier P, Armony JL, Driver J, Dolan RJ. 2001. Effects of attention and emotion on face processing in the human brain: an event-related fMRI study. Neuron 30(3):829-41.

Wojciulik E, Kanwisher N, Driver J. 1998. Covert visual attention modulates face-specific activity in the human fusiform gyrus: fMRI study. J Neurophysiol 79(3):1574-8.

Yovel G, Kanwisher N. 2004. Face perception: domain specific, not process specific. Neuron 44(5):889-98. 



\section{CHAPTER VI}

\section{Triggering vital alarms. Administration of $7 \% \quad \mathrm{CO}_{2}$ in panic disorder patients and healthy controls: pilot data}

L. Goossens, G. Esquivel, R. Peeters, I. Knuts, W. Backes, P. Hofman, E. Griez, K. Schruers 


\section{Abstract}

Panic disorder (PD) is a quite common condition (lifetime prevalence is 4\%) that significantly affects people's quality of life. An important theory concerning the nature and cause of PD is the "suffocation false alarm theory" (Klein 1993). According to this theory everyone has such an alarm, but this alarm is supposed to be over-sensitive in people with PD. This alarm can be triggered by carbon dioxide ( $\mathrm{CO} 2)$.

The current pilot study aimed to investigate the neural correlates of $\mathrm{CO} 2$ in PD patients. Subjects comprised 11 patients and 9 healthy controls (HC). Brain activation was measured with functional magnetic resonance imaging (fMRI) during the inhalation of $7 \% \mathrm{CO} 2$.

Both PD patients and HC show an increase in activation in the anterior cingulate and insular cortex during the inhalation of the heightened $\mathrm{CO} 2$ concentration. 


\section{Introduction}

The neurobiology of panic disorder is not yet fully understood. The clinical picture of this disorder is characterized by the occurrence of panic attacks. These attacks are short-lived periods with feelings of extreme fear and dread which are accompanied by marked neurovegetative symptoms.

In exploring the neuroanatomical correlates of panic, ethoexperimental analyses of defence strategies in animals should be taken into account. Results from this kind of studies classify the organisation of defensive mechanisms according to concepts of distance and defensive direction (Blanchard and Blanchard, 1988; Gray and McNaughton, 2000). Different types of defensive strategies can be distinguished depending on the distance to a (potential) threat. Existence of a potential threat, but not actually present, is associated with vigilance and risk assessment on a behavioural level. Distal threat, meaning still at some distance, causes a freezing response. Finally, undirected escape or fight characterizes proximal threat. Studies extrapolating these defence mechanisms towards human behaviour show similar patterns in defensive strategies to non-human mammals (Blanchard et al., 2001; Shuhama et al., 2008).

The hierarchy of defensive behaviours was linked to a matching neural hierarchy by Deakin and Graeff (Deakin and Graeff, 1991; Graeff, 1994). Rostral brain structures such as the prefrontal cortex are linked to potential threat, while more caudal areas like the brainstem play a more prominent role in proximal threat.

Extrapolating to the clinical settings, a panic attack corresponds to the most proximal defensive distance with the threat coming from within the body itself. According to Klein's false suffocation theory, pathological PA's may be false biological alarms, resulting from neuronal misfiring in an evolutionarily evolved, $\mathrm{CO}_{2}$ driven oversensitive suffocation monitor (Klein, 1993).

A research history of almost 30 years, has proven that panic patients are more sensitive to carbon dioxide than healthy people (Griez et al., 1987), and to a lesser extent also more than people with other anxiety disorders (Verburg et al., 2001).

Carbon dioxide and the accompanying changes in $\mathrm{pH}$ are mainly sensed in brainstem regions. $\mathrm{CO}_{2}$-sensitive neurons are demonstrated in the nucleus tractus solitarii (NTS), the serotonergic medullary raphe, the noradrenergic locus ceroeleus (LC), the preBötzinger complex, and the ventrolateral medullary surface with the retrotrapezoid nucleus (RTN) (Feldman et al., 2003; Putnam et al., 2004). Recent exciting evidence shows also serotonergic neurons of the midbrain raphe nuclei which might mediate nonrespiratory responses to increased carbon dioxide, such as arousal (Richerson, 2004). Functional neuroimaging studies administering gas 
mixtures with an elevated $\mathrm{CO}_{2}$ concentration, confirm the involvement of brainstem regions in the human response to hypercapnia (Brannan et al., 2001; Corfield et al., 1995; Gozal et al., 1994). Moreover, several limbic structures, such as the amygdala, anterior cingulate cortex and the insula showed increased activation in response to $\mathrm{CO}_{2}$. Liotti and colleagues correlated these responses to the affective component of air hunger associated with the inhalation of $\mathrm{CO}_{2}$ (Liotti et al., 2001).

The same limbic areas have also been implicated in functional neuroimaging studies on panic disorder (Bremner et al., 2000; De Cristofaro et al., 1993). Structural magnetic resonance imaging studies on panic disorder mainly report on a higher incidence of anatomical abnormalities mainly in the temporal lobe (Massana et al., 2003a; Massana et al., 2003b; Vythilingam et al., 2000).

The present study seeks to investigate differences in functional brain activation in panic disorder patients and healthy individuals in response to $\mathrm{CO} 2$. The focus will lay on limbic structures and the brainstem putatively involved both in panic disorder and in the response to hypercapnia.

The current short report only presents preliminary data from an interim analysis of an ongoing study.

\section{Methods}

\section{Subjects}

Eleven panic disorder patients visiting the outpatient clinic of the Academic Anxiety Center in Maastricht, meeting the DSM-IV criteria for panic disorder (with or without agoraphobia) as main diagnosis, were recruited for this study. Patients were excluded if they had a current comorbid axis I diagnosis, except for specific phobia and hypochondria. They were at least two weeks medication free before the scanning session. An overview of the patients is shown in table I. Two patients had to be excluded from the image analysis due to improper image quality.

Healthy control subjects ( 6 males and 3 females; mean age: 42.2 years, SD: 8.5) were matched in age and sex to the remaining 9 patients ( 6 males and 3 females; mean age: 41.8 years, SD: 8.7). The healthy controls were free of any psychopathology, assessed by a structured psychiatric interview [Mini International Neuropsychiatric Interview, MINI, (Sheehan et al., 1998)]. Control subjects were excluded if they had a positive result on the $35 \% \mathrm{CO}_{2}$ inhalation test. A positive response was defined by an increase of $20 \mathrm{~mm}$ or more on the visual analogue scale of anxiety (VAS-A) and a rise of at least 4 symptoms on the panic symptom list (PSL) (Schruers et al., 2000). 
Table I. PD patient overview

\begin{tabular}{c|c|c|c}
\hline Patient & Age (years) & Sex & Duration of PD (years) \\
\hline 1 & 55 & M & n.k. \\
2 & 52 & F & n.k. \\
$\mathbf{3}$ & $\mathbf{2 5}$ & $\mathbf{F}$ & $\mathbf{2}$ \\
$\mathbf{4}$ & $\mathbf{2 3}$ & M & $\mathbf{7}$ \\
5 & 44 & M & 4 \\
6 & 35 & M & 6 \\
7 & 45 & M & 3 \\
8 & 35 & F & 13 \\
9 & 37 & M & 4 \\
10 & 28 & M & 3 \\
11 & 45 & F & 28 \\
\hline
\end{tabular}

n.k. = not known, marked in bold: patients excluded from analysis

\section{Study design}

The study design was adapted from van der Zande et al. (van der Zande et al., 2005). All subjects were scanned three times 4 minutes during which they breathed through a mouthpiece. The 4 minutes were divided in a two-minute continuous flow of $100 \%$ oxygen and the following 2 minutes a high $\mathrm{CO}_{2}$ gas mixture $\left(7 \% \mathrm{CO}_{2}, 93 \% \mathrm{O}_{2}\right)$ was delivered. A fitted nose clip ensured that the subject breathed through the mouthpiece.

The gas mixture was released in an open circuit at a rate of $15 \mathrm{lt} / \mathrm{min}$, designed to allow ad libidum breathing with minimal positive pressure or resistance. Subjects

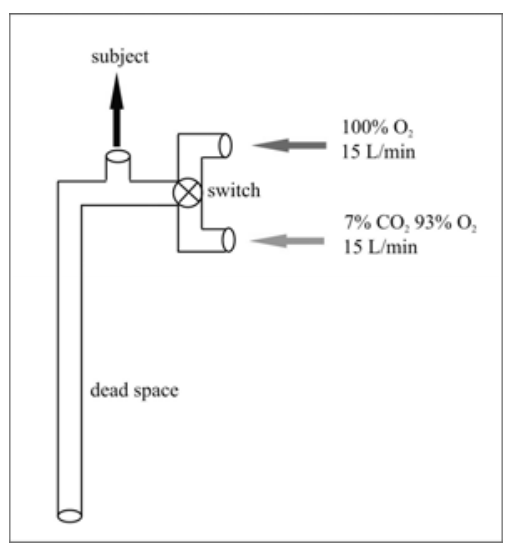

Fig. 1: Schematic drawing of the breathing device were instructed to breathe normally. Compliance was monitored by capnometry at the mouthpiece level which shows the respiratory rate and the amount of $\mathrm{CO} 2$ in the system. Furthermore, a researcher was always present in the scanning room to ensure a continuous breathing through the mouthpiece. A schematic of the breathing device can be found in fig. 1 . 


\section{Scanning procedure}

Brain images were acquired using a 3.0 Tesla Philips Intera scanner equipped with a standard head coil for radiofrequency transmission and signal reception. T2*-weighted echoplanar images (EPI) with bloodoxygenation level-dependent (BOLD) contrast, echo time $(T E)=33 \mathrm{~ms}$, repetition time $(T R)=3000 \mathrm{~ms}$, flip angle $=90^{\circ}$, slice thickness $4.0 \mathrm{~mm}$, interslice gap $0 \mathrm{~mm}$, field of view (FoV) $=230 \times 230 \times 136 \mathrm{~mm}$, matrix size 80 $x 80$, in-plane resolution $=2.88 \mathrm{~mm} \times 2.88 \mathrm{~mm}$. 34 Sagital slices per volume were positioned at an angle between the line crossing the anterior and posterior commissure (AC-PC line) and a line paralleling the medial tentorium cerebelli in order to reduce susceptibility artefacts. In addition, a high-resolution T1 anatomical image was obtained for each subject using a standard 3D MP-RAGE sequence.

\section{Data Analysis}

The functional images were realigned to the first volume of the time series to correct for head movements (four dummy images at the beginning of each time series were discarded for further analysis). After co-registering the functional images to the anatomical image, they were spatially normalized to the standard space of the Montreal Neurological Institute brain (MNI-brain). All functional images were sub-sampled to a voxel size of $2 \times 2 \times 2 \mathrm{~mm}$. Global signal changes induced by overall perfusion changes and blood oxygen content changes from the challenges or other sources were removed using a voxel-level linear model of the global signal (LMGS) (Macey et al., 2004). Detrended normalized images were smoothed with a Gaussian kernel of $6 \mathrm{~mm}$ full width at half maximum (FWHM).

First-level statistical analysis was done for all subjects in the context of the General Linear Model. In a first analysis path the $7 \% \mathrm{CO}_{2}$ condition was modeled as a single event (event-related design), and in a second path as a boxcar epoch-related function. In both pathways the models were convolved with a hemodynamic response function (hrf) and its time derivatives in the general linear model (GLM). This was done to visualize on the one hand brain areas which show a transient stimulus-induced hemodynamic response to the rise in $\mathrm{CO}_{2}$ and on the other hand brain areas with a steady-state synaptic activity and hemodynamics during the $\mathrm{CO}_{2}$ administration.

Individual contrast images were used in a second-level random effects analysis, which accounts for both scan-to-scan and subject-to-subject variability, to determine $\mathrm{CO}_{2}$-specific regional responses for within- and between-group statistical comparisons.

Because of an a priori hypothesis regarding the response in the amygdala, the insula, the anterior cingulate and the brainstem, a region of interest (ROI) analysis was conducted in these areas of the brain. ROIs were defined using the WFU Pick-Atlas (Maldjian et al., 2004; Maldjian et al., 
2003). The significance level was set at $P<0.05$, and corrected for multiple comparisons using the False Discovery Rate (Genovese et al., 2002).

\section{Results}

Modelling the $7 \% \mathrm{CO}_{2}$ condition as a single event in the within-group analyses showed significant increased activation in the anterior cingulate cortex (ACC, Brodmann area 32) and bilateral in the insula (Brodmann area 13) relative to the $\mathrm{O}_{2}$ baseline as well in PD patients (Talairach coordinates and statistical values of peak activation: ACC $[4,-24,27], t=4.93$; insula left $[-$ $36,21,3], \mathrm{t}=5.54$; insula $\left.a_{\text {right }}[40,19,1], \mathrm{t}=4.59\right)$ as in control subjects (Talairach coordinates and statistical values of peak activation: ACC $[4,-24$, 27], $\mathrm{t}=4.93$; insula left $[-42,13,-2], \mathrm{t}=4.35$; insula right $[40,16,-1], \mathrm{t}=4.76$ ) (fig.2). There were no significant epoch-related contributions in both groups. The between-groups analysis with a two sample t-test comparing the patients and the control subjects revealed no difference in brain activation in response to the $\mathrm{CO}_{2}$.

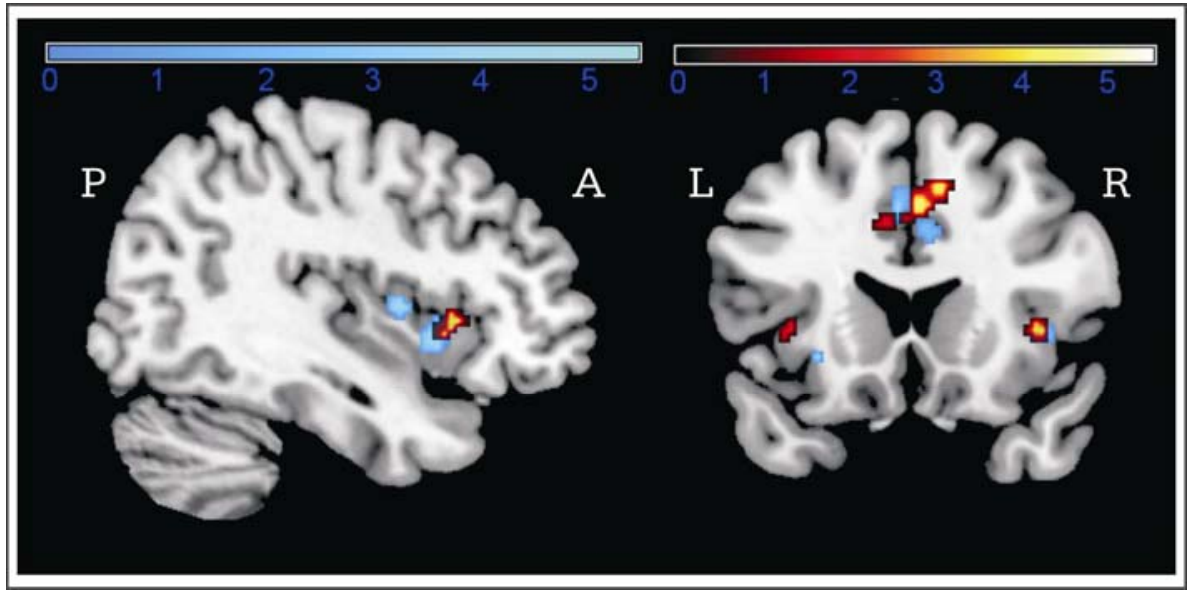

Fig. 2: The left panel shows a sagital activation map with significantly more blood oxygenation level dependent (BOLD) signal in the right insula during $\mathrm{CO}_{2}$ inhalation. The coronal slice in the left panel displays the increased actvation in the ACC. Activation for the HCs is designated in blue, and in orange for the PDs

\section{Discussion}

The present study shows in these preliminary analyses that both panic disorders patients and healthy control subjects have increased transient activation in the insular and anterior cingulate cortex in response to $\mathrm{CO} 2$ 
administration. There was no brainstem activation found, nor did the groups differ in their response.

\section{I nsula and ACC}

The insula and the anterior cingulate are usually activated in concert during states of autonomic arousal (Critchley et al., 2003). Both structures have direct and indirect connections with subcortical brain regions associated with homeostasis and autonomic control (Mesulam, 1985; Nieuwenhuys et al., 2008; Ongur et al., 1998). Increases in global cerebral blood flow in similar regions have been found in panic provocations studies with CCK and lactate (Benkelfat et al., 1995; Javanmard et al., 1999; Reiman et al., 1989). Moreover, activations in the insular cortex and the ACC have been reported in previous studies on hypercapnia (Banzett et al., 2000; Brannan et al., 2001; Corfield et al., 1995; Liotti et al., 2001). Liotti et al. (2000) and Banzett et al. (2001) correlated the involvement of these brain areas more specifically to the associated sense of breathlessness. Most probably, this will be the case in the present study as well. The majority of the subjects subjectively reported 'difficulties in breathing' as the most pronounced effect of the $\mathrm{CO}_{2}$ administration.

\section{Limitations}

Surprisingly, the present preliminary data don't show significant findings in brainstem regions, neither in within- nor in between-group comparisons. This can be due to the lack of power. The current short report only presents preliminary data with 9 subjects. With a total sample size of 15 in each group, a one way analysis of variance will have $90 \%$ power to detect at the 0.05 level a difference in means characterized by a variance of means in cerebral blood flow $(\mathrm{ml} / \mathrm{min} / 100 \mathrm{~g}), \mathrm{V}=\Sigma\left(\mu_{\mathrm{i}}-\mu\right)^{2} / \mathrm{G}$ of 75.00 , assuming that the common standard deviation is 15.00 [sample size calculated from a previous positron emission tomography study (Reiman et al., 1986)].

However, it is worth mentioning that previous studies reporting on the response to hypercapnia show inconsistencies in brainstem results. A previous study with a comparable set-up (Harper et al., 2005) found a significant decrease in the dorsal pons in response to 2 minutes of $5 \% \mathrm{CO} 2$ in healthy children. Brannan et al. (2001), on the other hand, showed increases in similar brainstem regions in adults. Furthermore, the lack of brainstem activation can be due to a bad signal-to-noise ratio in this area. It is susceptible to respiratory (Van de Moortele et al., 2002) and cardiac (Dagli et al., 1999) noise due to varying effects of blood and cerebrospinal fluid flow during the cardiac cycle (Friese et al., 2004), and due to magnetic field changes caused by the varying lung volume during the respiratory cycle (Windischberger et al., 2002). Also swallowing can contribute to motion artefacts in the brainstem. This was caused by the sense of a 'dry mouth' as 
reported by most participants. This is a limitation inherent to the present breathing device set-up.

\section{Future directions}

The present ongoing study will recruit more subjects in order to gain more power. Further analyses will include modelling the hemodynamic response with other functions than the basic hrf supplied in SPM to make a better fit of the response to increased $\mathrm{CO}_{2}$. Also, correlation analyses can be done with the subjective measures of the VAAS and PSL.

Furthermore, a first rough visual inspection of the end tidal $\mathrm{CO}_{2}$ percentages shows subjects to respond to the $\mathrm{CO}_{2}$ with a deeper breathing overcoming the dead space. During the first 30 seconds, inspiratory and end tidal levels of $\mathrm{CO} 2$ remain well high around $6.5 \%$. Afterwards, although end tidal $\mathrm{CO} 2$ remains at this level, respiratory levels of $\mathrm{CO} 2$ begin to decrease as room air enters the circuit via the dead space tube as a result of the subject's deep breaths. This can be overcome by future experiments delivering a larger quantity of air (perhaps more than $201 / \mathrm{min}$ ) or using a closed circuit allowing subjects to rebreath. The difference in the first 30s of $\mathrm{CO} 2$-inhalation and the remaining seconds can be taken into account in future analyses as well. 


\section{References}

Banzett RB, Mulnier HE, Murphy K, Rosen SD, Wise RJ, Adams L. 2000. Breathlessness in humans activates insular cortex. Neuroreport 11(10):2117-20.

Benkelfat C, Bradwejn J, Meyer E, Ellenbogen M, Milot S, Gjedde A, Evans A. 1995. Functional neuroanatomy of CCK4-induced anxiety in normal healthy volunteers. Am J Psychiatry 152(8):1180-4.

Blanchard DC, Blanchard RJ. 1988. Ethoexperimental approaches to the biology of emotion. Annu Rev Psychol 39:43-68.

Blanchard DC, Hynd AL, Minke KA, Minemoto T, Blanchard RJ. 2001. Human defensive behaviors to threat scenarios show parallels to fear- and anxiety-related defense patterns of non-human mammals. Neurosci Biobehav Rev 25(7-8):761-70.

Brannan S, Liotti M, Egan G, Shade R, Madden L, Robillard R, Abplanalp B, Stofer K, Denton D, Fox PT. 2001. Neuroimaging of cerebral activations and deactivations associated with hypercapnia and hunger for air. Proc Natl Acad Sci U S A 98(4):2029-34.

Bremner JD, Innis RB, White T, Fujita M, Silbersweig D, Goddard AW, Staib L, Stern E, Cappiello A, Woods S and others. 2000. SPECT [I-123]iomazenil measurement of the benzodiazepine receptor in panic disorder. Biological Psychiatry 47(2):96-106.

Corfield DR, Fink GR, Ramsay SC, Murphy K, Harty HR, Watson JD, Adams L, Frackowiak RS, Guz A. 1995. Evidence for limbic system activation during CO2-stimulated breathing in man. J Physiol 488 ( Pt 1):77-84.

Critchley HD, Mathias CJ, Josephs O, O'Doherty J, Zanini S, Dewar BK, Cipolotti L, Shallice T, Dolan RJ. 2003. Human cingulate cortex and autonomic control: converging neuroimaging and clinical evidence. Brain 126(Pt 10):2139-52.

Dagli MS, Ingeholm JE, Haxby JV. 1999. Localization of cardiac-induced signal change in fMRI. Neuroimage 9(4):407-15.

De Cristofaro MTR, Sessarego A, Pupi A, Biondi F, Faravelli C. 1993. Brain perfusion abnormalities in drug-naive, lactate-sensitive panic patients: A SPECT study. Biological Psychiatry 33(7):505-512.

Deakin JF, Graeff FG. 1991. 5-HT and mechanisms of defence. J Psychopharmacol 5(4):305315.

Feldman JL, Mitchell GS, Nattie EE. 2003. Breathing: rhythmicity, plasticity, chemosensitivity. Annu Rev Neurosci 26:239-66.

Friese S, Hamhaber U, Erb M, Kueker W, Klose U. 2004. The influence of pulse and respiration on spinal cerebrospinal fluid pulsation. Invest Radiol 39(2):120-30.

Genovese CR, Lazar NA, Nichols T. 2002. Thresholding of statistical maps in functional neuroimaging using the false discovery rate. Neuroimage 15(4):870-8.

Gozal D, Hathout GM, Kirlew KA, Tang H, Woo MS, Zhang J, Lufkin RB, Harper RM. 1994. Localization of putative neural respiratory regions in the human by functional magnetic resonance imaging. J Appl Physiol 76(5):2076-2083.

Graeff FG. 1994. Neuroanatomy and neurotransmitter regulation of defensive behaviors and related emotions in mammals. Braz J Med Biol Res 27(4):811-29.

Gray JA, McNaughton N. 2000. The Neuropsychology of Fear. Oxford: Oxford University Press.

Griez EJ, Lousberg H, van den Hout MA, van der Molen GM. 1987. CO2 vulnerability in panic disorder. Psychiatry Res 20(2):87-95.

Harper RM, Macey PM, Woo MA, Macey KE, Keens TG, Gozal D, Alger JR. 2005. Hypercapnic exposure in congenital central hypoventilation syndrome reveals CNS respiratory control mechanisms. J Neurophysiol 93(3):1647-58.

Javanmard M, Shlik J, Kennedy SH, Vaccarino FJ, Houle S, Bradwejn J. 1999. Neuroanatomic correlates of CCK-4-induced panic attacks in healthy humans: a comparison of two time points. Biol Psychiatry 45(7):872-82.

Klein DF. 1993. False suffocation alarms, spontaneous panics, and related conditions. An integrative hypothesis. Arch Gen Psychiatry 50(4):306-17. 
Liotti M, Brannan S, Egan G, Shade R, Madden L, Abplanalp B, Robillard R, Lancaster J, Zamarripa FE, Fox PT and others. 2001. Brain responses associated with consciousness of breathlessness (air hunger). Proc Natl Acad Sci U S A 98(4):2035-40.

Macey PM, Macey KE, Kumar R, Harper RM. 2004. A method for removal of global effects from fMRI time series. Neuroimage 22(1):360-6.

Maldjian JA, Laurienti PJ, Burdette JH. 2004. Precentral gyrus discrepancy in electronic versions of the Talairach atlas. Neuroimage 21(1):450-5.

Maldjian JA, Laurienti PJ, Kraft RA, Burdette JH. 2003. An automated method for neuroanatomic and cytoarchitectonic atlas-based interrogation of fMRI data sets. Neuroimage 19(3):1233-9.

Massana G, Serra-Grabulosa JM, Salgado-Pineda P, Gasto C, Junque C, Massana J, Mercader JM. 2003a. Parahippocampal gray matter density in panic disorder: a voxel-based morphometric study. Am J Psychiatry 160(3):566-8.

Massana G, Serra-Grabulosa JM, Salgado-Pineda P, Gasto C, Junque C, Massana J, Mercader JM, Gomez B, Tobena A, Salamero M. 2003b. Amygdalar atrophy in panic disorder patients detected by volumetric magnetic resonance imaging. Neuroimage 19(1):80-90.

Mesulam MM. 1985. The insula of Reil in man and monkey. In: Jones EG, Peters AA, editors. Cerebral Cortex. New York: Plenum Press.

Nieuwenhuys R, Voogd J, van Huijzen FMAA. 2008. The human central nervous system. Berlin: Springer-Verlag.

Ongur D, An X, Price JL. 1998. Prefrontal cortical projections to the hypothalamus in macaque monkeys. J Comp Neurol 401(4):480-505.

Putnam RW, Filosa JA, Ritucci NA. 2004. Cellular mechanisms involved in $\mathrm{CO}(2)$ and acid signaling in chemosensitive neurons. Am J Physiol Cell Physiol 287(6):C1493-526.

Reiman EM, Raichle ME, Robins E, Butler FK, Herscovitch P, Fox P, Perlmutter J. 1986. The application of positron emission tomography to the study of panic disorder. Am J Psychiatry 143(4):469-77.

Reiman EM, Raichle ME, Robins E, Mintun MA, Fusselman MJ, Fox PT, Price JL, Hackman KA. 1989. Neuroanatomical correlates of a lactate-induced anxiety attack. Arch Gen Psychiatry 46(6):493-500.

Richerson GB. 2004. Serotonergic neurons as carbon dioxide sensors that maintain pH homeostasis. Nat Rev Neurosci 5(6):449-61.

Schruers K, Klaassen T, Pols H, Overbeek T, Deutz NE, Griez E. 2000. Effects of tryptophan depletion on carbon dioxide provoked panic in panic disorder patients. Psychiatry Res 93(3):179-87.

Sheehan DV, Lecrubier Y, Sheehan KH, Amorim P, Janavs J, Weiller E, Hergueta T, Baker R, Dunbar GC. 1998. The Mini-International Neuropsychiatric Interview (M.I.N.I.): the development and validation of a structured diagnostic psychiatric interview for DSM-IV and ICD-10. J Clin Psychiatry 59 Suppl 20:22-33;quiz 34-57.

Shuhama R, Del-Ben CM, Loureiro SR, Graeff FG. 2008. Defensive responses to threat scenarios in Brazilians reproduce the pattern of Hawaiian Americans and non-human mammals. Braz J Med Biol Res 41(4):324-32.

Van de Moortele PF, Pfeuffer J, Glover GH, Ugurbil K, Hu X. 2002. Respiration-induced B0 fluctuations and their spatial distribution in the human brain at 7 Tesla. Magn Reson Med 47(5):888-95.

van der Zande FH, Hofman PA, Backes WH. 2005. Mapping hypercapnia-induced cerebrovascular reactivity using BOLD MRI. Neuroradiology 47(2):114-20.

Verburg K, Perna G, Griez EJL. 2001. A case study of the 35\% CO2 challenge. In: Griez EJL, Faravelli C, Nutt DJ, Zohar J, editors. Anxiety disorders: an introduction to clinical management and research Chichester: John Wiley \& Sons, Ltd.

Vythilingam M, Anderson ER, Goddard A, Woods SW, Staib LH, Charney DS, Bremner JD. 2000. Temporal lobe volume in panic disorder--a quantitative magnetic resonance imaging study. Psychiatry Res 99(2):75-82. 
Triggering Vital Alarms

Windischberger C, Langenberger H, Sycha T, Tschernko EM, Fuchsjager-Mayerl G, Schmetterer L, Moser E. 2002. On the origin of respiratory artifacts in BOLD-EPI of the human brain. Magn Reson Imaging 20(8):575-82. 
CHAPTER VI I

Summary \& Concluding Remarks 
The aim of the present thesis was to map the neural correlates of fear and panic in the human brain using experimental models for psychopathology.

The first part was mainly concentrated on fear and the pivotal role of the amygdala. At the starting point of this work, most data on the involvement of the amygdala in the defensive response was derived from animal research. Especially fear conditioning studies in rodents implicated the amygdala in processes such as fear acquisition and the mobilisation of fear responses (Davis, 1997; LeDoux, 1994). The rise of neuroimaging techniques in the late nineties offered new opportunities. The human amygdala was shown to be responsive to fearful faces (Morris et al., 1996). Also in humans, fear conditioning seemed to be associated with the amygdala (Buchel et al., 1998; LaBar et al., 1998).

Looking into pathological models of fear, and bearing the theory of the defensive hierarchy in mind, amygdala involvement in specific phobia is to be expected. People suffering from this disorder show an exaggerated fear response to a well defined stimulus. However, previous studies on phobia did not demonstrate amygdala activation. By using an adapted eventrelated paradigm for functional MRI, we were able to show heightened amygdala activation in phobic subjects when viewing pictures of spiders compared to healthy controls. Activation of the anterior cingulate (ACC) and the insular cortex was also found and interpreted in the light of the 'limbic motor and sensory cortex' (Craig, 2003).

The fear seen in specific phobia can be diminished or extinguished by exposure therapy. The functional changes in this kind of 'safety learning' can give a major contribution to the underlying fear circuit. Data presented in the third chapter revealed that the amygdala hyperreactivity could be overcome by a single intensive session of cognitive-behavioural therapy. It was the first study in humans to show that this kind of desensitisation acted on the subcortical level. Moreover, a positive linear correlation between amygdala activity and the amount of fear was also found, indicating a direct relationship between amygdala reactivity and therapy success.

The following chapter showed that the extinction not only induces functional changes on the level of the grey matter structures, but also influences the white matter connections. Although the exact molecular mechanisms behind a change in FA-value are still unclear, the robust decrease in FA values point to the fact the effect of behaviour on the connections between different structures can not be ignored.

The above described first part of the present thesis confirms the pivotal role of the amygdala in the human fear process. However, it is important to keep two things in mind concerning the amygdala. First, it is worth mentioning that this structure is not only important for fear processing, but also for other stimuli or situations which are essential for an individual's 
survival (Sander et al., 2003). Second, we have to realise that the amygdala is not a single uniform structure, but rather consists of different subgroups of nuclei. From animal studies it was already clear that different parts of the amygdala support different processes in for example fear acquisition [(LeDoux, 2007) see introduction].

By means of probabilistic maps of the different subgroups of the amygdala, the proof of concept study in chapter five shows that facial stimuli are preferentially processed in the superficial group of the amygdala, regardless of the valence or the expressed emotion on the faces.

The final chapter concerns neural responses at the closest defensive distance, namely: bodily internal stimuli. The preliminary results show that the administration of $7 \% \mathrm{CO}_{2}$ activates the ACC and the insular cortex, both in panic disorder patients and in healthy control subjects.

Although the experimental model for panic of $\mathrm{CO}_{2}$ inhalation has already been described since the 1980s (Gorman et al., 1984; Van den Hout and Griez, 1984), the exact underlying neurobiological mechanisms still remain still unclear. Neuroimaging studies on $\mathrm{CO}_{2}$ mainly implicate brainstem and limbic structures (Brannan et al., 2001). The ACC and insula are more specifically associated with the consciousness of breathlessness provoked by hypercapnia (Liotti et al., 2001). These structures are also implicated in the process of other primal emotions such as thirst and hunger. Primal emotions rise from vegetative systems and completely occupy our consciousness with a singular compelling sensation and intention. They are largely interoceptor driven and in this way signal that the individual's existence is immediately threatened (Denton, 2005). The brain structures found to be responsive to $\mathrm{CO} 2$ inhalation in the last chapter, ACC and the insula, could give rise to the conscious state of these emotions. There seems to be no difference in the consciousness processing of breathlessness in panic disorders patients and healthy individuals. Due to several technical limitations, we were not able to study the effect of hypercapnia in more caudal brainstem regions. As shown from animal studies, the periaqueductal gray and the dorsal raphe nuclei can be implicated in panic (Graeff, 2004). Therefore, it makes sense to study the brainstem in more detail by adjusting imaging techniques and breathing devices in the future.

The present thesis only shows a tip of the iceberg in the process of fear and panic. Many questions are still left to be answered. Especially given the importance of these processes in the underlying neurobiology of anxiety disorders, future research is necessary.

In today's ever-changing society, it is important to be able to adjust our behaviour depending on the variety of threatening situations. This ability is impaired in people suffering from anxiety disorders. They show an 
inappropriate response to current circumstances. Expanding our focus to the biological mechanisms of fear and safety learning can be an excellent starting point in disentangling the maladaptiveness of the defensive response in anxiety disorders.

It is not only important to know which structures are involved but also which biological underlying processes play a role in the formation of such memories, and even further how they are genetically determined. Data from both animal and human studies support the hypothesis that genetic factors may influence conditionability (Hettema et al., 2003).

Studies combining genetics and neuroimaging have recently shown great promise as an avenue to gain insight into the neurobiology of affective dysfunction. Functional polymorphisms might be more strongly related to functional and structural integrity of underlying neural systems than to externally observable changes in affect or behaviour. Genes offer the potential to identify at-risks individuals and biologic pathways for the development of new treatments.

Combining the paradigms of fear conditioning and extinction in a neuroimaging setting together with genetic polymorphisms can bring us a step closer to identify individuals vulnerable to the development of anxiety disorders or in a next step might us even show which patients might profit from psychotherapy.

An interesting starting point in this line of research can be found in the involvement of $\mathrm{N}$-methyl-D-aspartaat (NMDA) receptors in the acquisition and extinction of fear. The fact that NMDA receptors in the amygdala are critical not only for excitatory but also for inhibitory fear conditioning has been known for a long time (Falls et al 1992). Recently, extending these findings to humans, it became clear that these NMDA receptors may also be a target for drugs to facilitate fear extinction in the framework of psychological therapies for anxiety and fear disorders. The partial NMDA receptor agonist, D-cycloserine (DCS), given prior to the exposure therapy, tends to improve fear reduction of social phobia and fear of heights in these human studies (Guastella et al., 2007; Kushner et al., 2007).

Combining the used magnetic resonance imaging techniques in the present thesis with genotyping and pharmacological challenges can be a further step to unravel the neurobiological underpinnings of fear and safety learning. 


\section{References}

Brannan S, Liotti M, Egan G, Shade R, Madden L, Robillard R, Abplanalp B, Stofer K, Denton D, Fox PT. 2001. Neuroimaging of cerebral activations and deactivations associated with hypercapnia and hunger for air. Proc Natl Acad Sci U S A 98(4):2029-34.

Buchel C, Morris J, Dolan RJ, Friston KJ. 1998. Brain systems mediating aversive conditioning: an event-related fMRI study. Neuron 20(5):947-57.

Craig AD. 2003. Interoception: the sense of the physiological condition of the body. Current Opinion in Neurobiology 13(4):500-505.

Davis M. 1997. Neurobiology of fear responses: the role of the amygdala. J Neuropsychiatry Clin Neurosci 9(3):382-402.

Denton D. 2005. The primordial emotions. The Dawning of consciousness. New York: Oxford University Press Inc.

Gorman JM, Askanazi J, Liebowitz MR, Fyer AJ, Stein J, Kinney JM, Klein DF. 1984. Response to hyperventilation in a group of patients with panic disorder. Am J Psychiatry 141(7):85761.

Graeff FG. 2004. Serotonin, the periaqueductal gray and panic. Neurosci Biobehav Rev 28(3):239-59.

Guastella AJ, Dadds MR, Lovibond PF, Mitchell P, Richardson R. 2007. A randomized controlled trial of the effect of D-cycloserine on exposure therapy for spider fear. J Psychiatr Res 41(6):466-71.

Hettema JM, Annas P, Neale MC, Kendler KS, Fredrikson M. 2003. A twin study of the genetics of fear conditioning. Arch Gen Psychiatry 60(7):702-8.

Kushner MG, Kim SW, Donahue C, Thuras P, Adson D, Kotlyar M, McCabe J, Peterson J, Foa EB. 2007. D-cycloserine augmented exposure therapy for obsessive-compulsive disorder. Biol Psychiatry 62(8):835-8.

LaBar KS, Gatenby JC, Gore JC, LeDoux JE, Phelps EA. 1998. Human amygdala activation during conditioned fear acquisition and extinction: a mixed-trial fMRI study. Neuron 20(5):937-45.

LeDoux J. 2007. The amygdala. Current Biology 17(20):R868-R874.

LeDoux JE. 1994. Emotion, memory and the brain. Sci Am 270(6):50-7.

Liotti M, Brannan S, Egan G, Shade R, Madden L, Abplanalp B, Robillard R, Lancaster J, Zamarripa FE, Fox PT and others. 2001. Brain responses associated with consciousness of breathlessness (air hunger). Proc Natl Acad Sci U S A 98(4):2035-40.

Morris JS, Frith CD, Perrett DI, Rowland D, Young AW, Calder AJ, Dolan RJ. 1996. A differential neural response in the human amygdala to fearful and happy facial expressions. Nature 383(6603):812-5.

Sander D, Grafman J, Zalla T. 2003. The human amygdala: an evolved system for relevance detection. Rev Neurosci 14(4):303-16.

Van den Hout MA, Griez E. 1984. Panic symptoms after inhalation of carbon dioxide. $\mathrm{Br}$ J Psychiatry 144:503-7. 

NEDERLANDSE SAMENVATTI NG 
Vanuit ethologische experimenten wordt een onderscheid gemaakt tussen de fenomenen angst, vrees en paniek naargelang de afstand die bestaat tussen een mens of dier en een bron van gevaar. De reactie die optreedt bij een potentieel gevaar op vrij grote afstand noemt men angst. De respons op een nabije, actuele bedreiging heet vrees. De reactie op gevaar afkomstig vanuit het eigen lichaam, met afstand nul dus, noemen we paniek.

Het doel van dit proefschrift is het in kaart brengen van de neurale mechanismen van vrees en paniek. Hiertoe werd gebruik gemaakt van een combinatie van experimentele psychopathologie en magnetische resonantie beeldvorming.

Het grootste gedeelte van de studies gaat over de rol van de amygdala in vrees. Uit dierstudies blijkt dat de amygdala een centrale rol heeft in de hersencircuits die defensieve responsen sturen. Activatie van deze amandelvormige structuur leidt tot een fysiologische mobilisatie cascade, verhoogde waakzaamheid, en de neiging tot vluchten uit een gevaarlijke situatie.

Specifieke fobie kan beschouwd worden als een naturalistisch en realistisch model om vrees te bestuderen. Fobische mensen vertonen een overdreven vreesrespons op een welbepaalde stimulus en hebben meestal geen andere psychiatrische klachten. In hoofdstuk twee tot vier gebruiken we specifieke fobie dan ook als pathologisch model voor vrees.

De studie in hoofdstuk twee maakt gebruik een aangepast 'event-related' fMRI paradigma. Er wordt aangetoond dat fobische individuen verhoogde amygdala activiteit vertonen vergeleken met controle personen bij het kijken naar foto's van spinnen. Ook is er verhoogde activiteit in de gyrus cinguli anterior en de insula. Deze laatste hersengebieden maken deel uit van de limbische motorische en sensorische cortex.

In een volgende stap werden fobische patiënten behandeld voor hun fobie door middel van gedragstherapie. Hoofdstuk drie tracht dan ook te achterhalen welke hersengebieden betrokken kunnen zijn bij het afleren van vrees. De reactie op visuele presentatie van spinnen werd onderzocht tijdens een fMRI scan zowel voor als na de gedragstherapie. Het blijkt dat de hyperreactiviteit in de amygdala verminderd kan worden door een éénmalige intensieve sessie gedragstherapie. Bovendien is het klinische succes van de behandeling recht evenredig met de reactiviteit van de amygdala op deze bedreigende stimuli. Dit is een eerste studie die erop wijst dat er sprake is van desensitisatie ter hoogte van subcorticale structuren en niet van een toegenomen remming door hogere prefrontale hersengebieden.

Hoofdstuk vier gaat nog een stap verder. Deze studie toont aan dat er niet enkel functionele veranderingen optreden na therapie, maar ook structurele veranderingen in de witte stof die de verbinding verzorgt tussen verschillende hersengebieden. Door middel van 'diffusion tensor imaging' (DTI) werd een consistente daling in de fractionele anisotropie (FA) waarde 
gevonden rondom de amygdala na gedragstherapie. De exacte onderliggende moleculaire mechanismen van de FA-waarde bij DTI zijn nog niet helemaal duidelijk. Toch wijst de studie in hoofdstuk 4 erop dat veranderingen in gedrag op korte termijn kunnen leiden tot structurele veranderingen in de hersenen.

De amygdala wordt vaak beschouwd als een uniform geheel. Deze structuur bestaat echter uit verschillende subgroepen van kernen. Uit dierstudies blijkt dat deze subgroepen verschillende processen ondersteunen tijdens vreesconditionering (kort beschreven in hoofdstuk 1).

De subgroepen zijn niet goed te onderscheiden wanneer alleen gebruik gemaakt wordt van de huidige beeldvormingtechnieken. We kunnen wel een goed idee krijgen door gebruik te maken van een zogenaamde probabilistische kaart van de amygdala. Op basis van postmortem studies is er een probabilistische kaart gemaakt van de amygdala.

De studie beschreven in hoofdstuk vijf combineert deze kaart met een fMRI paradigma dat bekend staat om zijn robuuste amygdala activatie, namelijk: het kijken naar foto's van menselijke gezichten. Het blijkt dat gezichten vooral de superficiële subgroep van de amygdala activeren, onafhankelijk van de emotionele expressie.

Hoofdstuk zes gaat over paniek, de defensieve respons op bedreigingen vanuit het eigen lichaam. Het is reeds lang bekend dat inhalatie van een verhoogde concentratie van $\mathrm{CO}_{2}$ een paniekaanval kan veroorzaken. De exacte onderliggende neurobiologische mechanismen hiervan zijn echter nog steeds onduidelijk.

De preliminaire resultaten van hoofdstuk zes tonen aan dat het toedienen van $7 \% \mathrm{CO}_{2}$ de gyrus cinguli anterior en de insula activeert, zowel in mensen met een paniekstoornis als in controle personen. Deze hersengebieden worden geassocieerd met het bewuste gevoel van ademnood dat uitgelokt wordt door $\mathrm{CO}_{2}$. Ademnood kan gezien worden als een zogenaamde primaire emotie waartoe bijvoorbeeld ook honger en dorst behoren. Het beleven van deze laatste emoties gaat gepaard met activiteit in dezelfde hersengebieden.

Uit dierstudies blijkt dat ook de substantia grisea centralis en de nuclei raphes een rol hebben in paniek. Door technische limitaties kon deze studie echter nog geen uitsluitsel bieden over de implicaties van $\mathrm{CO}_{2}$ op deze meer caudale hersenstam gebieden. Deze studie zal dus in de toekomst verder uitgebreid worden.

Dit proefschrift belicht slechts een klein deel van de onderliggende processen van vrees en paniek.

In onze snel veranderende omgeving is het zeer belangrijk om gedrag aan te passen aan verschillende situaties. Het vermogen tot aanpassen is 
verstoord bij mensen met angststoornissen. Zij vertonen een overreactie in situaties die in werkelijkheid niet bedreigend zijn.

Om meer inzicht te krijgen in deze stoornissen is het dan ook wenselijk om in de toekomst verder onderzoek te verrichten naar de biologische mechanismen van het aan- en afleren van vrees. Deze processen vormen een uitstekend startpunt om de neurobiologie te onderzoeken van zulk een defensieve overreactie. Voorstellen voor verder onderzoek worden gesuggereerd in hoofdstuk zeven. 


\section{DANKWOORD}


Eindelijk aangekomen bij het laatste gedeelte van dit proefschrift: het Grote Dankwoord. Al deze jaren zijn er ettelijke personen de revue gepasseerd die op één of andere manier hebben bijgedragen tot het tot stand brengen van dit werk. Meerdere malen heb ik nagedacht hoe ik iedereen speciaal aan bod kan laten komen in dit dankwoord. Het zal een hele boterham worden, dus: here we go ...

Als eerste gaat mijn dank uit naar mijn promotor professor Griez.

Beste Eric, bedankt voor alle kansen die u me geboden heeft deze afgelopen jaren. Ondanks dat het een tijdje duurde vooraleer er resultaten kwamen uit de studies met die 'grote machine', heb ik me steeds gesteund gevoeld door $u$. $U$ heeft me niet enkel laten ontplooien op het gebied van onderzoek, maar ook op het gebied van organisatie toen u me de rol als academisch coördinator aanbood bij de Master of Affective Neuroscience. De contacten die ik hierdoor kon leggen, hebben me al heel snel laten proeven van de internationale wetenschapswereld. Bedankt voor de leuke samenwerking, u heeft me veel wijsheid bijgebracht deze afgelopen jaren. bedankt voor alles!

$\mathrm{Nu}$ zou ik moeten schrijven 'als tweede gaat mijn dank uit naar', maar eigenlijk is het nog steeds als eerste: Koen, mijn copromotor.

Koen, waar moet ik beginnen? Ik kan echt zeggen: "moest jij er niet geweest zijn, dan stond ik hier nu niet vandaag". Niet alleen door het feit dat jij me naar Maastricht gehaald hebt, maar vooral door de manier waarop je me de afgelopen jaren begeleid en bijgestaan hebt. Ik kon steeds bij je binnenlopen om de meest uiteenlopende zaken te bespreken en te bediscussiëren, al ging het nu over onderzoek of 'welke wijn past het beste bij dat soort gerecht'. Ook als ik even het bos niet meer door de bomen zag, was jij daar om me op te krikken en me met raad en daad bij te staan. Bedankt voor je vertrouwen in mij dat steeds mijn zelfvertrouwen weer de boost gaf die ik nodig had.

Voordat ik in Maastricht ben aanbeland, heb ik mijn eerste stapjes in het onderzoek gezet op de afdeling radiologie van het UZ Leuven onder de begeleiding van mijn tweede co-promotor Stefan Sunaert.

Stefan, jij hebt me zes jaar geleden aangespoord om aan het Maastrichtavontuur te beginnen en het onderzoeksleven in te gaan. Bedankt dat je hierin mijn co-promotor wou zijn en zo ook mogelijkheden creëerde om samen verder onderzoek uit te voeren op fase 3.

Ik heb je steeds bewonderd om je inzicht en didactisch vermogen. Je kon de meest ingewikkelde dingen zeer simpel laten lijken. Bedankt om me wegwijs te maken in de wereld van imaging. Ondanks je drukke agenda vond je altijd toch wel even tijd om analyses te bekijken, papers te lezen, DTIprincipes duidelijk te maken, ... noem maar op. Dankjewel! 
Aan de Leuvense zijde gaat er ook een dikke merci uit naar Ronald Peeters. Ron, man, man, hoeveel keer heb ik jou niet bestookt met mailtjes en telefoontjes, of met bezoekjes, als matlab en SPM (of beter gezegd mijn vermogen tot programmeren) het weer eens lieten afweten. Jij had altijd wel een oplossing klaar. Niets was te veel. Bedankt voor alle geduldige hulp en de bijbehorende PIMs momenten. Je hebt wel 100 -en dozen verdiend ... met appelsien, framboos of chocomousse, kies maar!

Aangekomen in Maastricht, kreeg ik een kamer op de onderzoeksgang. In het begin was het hier wat eenzaam, maar dat veranderde allemaal met de komst van de beste Mexicaanse collega ooit.

Gabriel, actually I should express my thanks to you in Dutch now. However, I will not tease you and just continue in English. You were the one who finally brought some life in the research hallway. Thanks for being just you: patient and always time to explain things. Especially thanks for sacrificing several evenings to scan in the azM. And thank you Tineke for borrwing him to me $\odot$. . Gabriel, it was, and stil is, fun to have you as a colleague, and on top of that as a friend. Thank you for standing next to me today. I will share food with you any time and you are always welcome to have a Bicky Burger at my place!

Even later werd het nog gezelliger op de gang toen Marlies van beneden naar boven verhuisde. Eindelijk had ik een kamergenote. Marlies, jij bent waarschijnlijk de meest geduldigste persoon die ik ken. Ik wou dat ik maar half zo rustig als jou kon blijven. Bedankt voor alle babbeltjes over vanalles en nog wat. Hopelijk kunnen we nog een tijdje doorgaan.

Mede door jou, Marlies, kreeg ik wat meer contact met de meiden van beneden. Ook de toffe summer course met Klara en Jaimie zat hier voor iets tussen. Bedankt Klara, Cindy, Femmie, Jaimie en Nicole voor de AACmeiden-etentjes, en niet te vergeten de geweldige sinterklaas momenten. Volgend jaar moeten er wel weer badspeeltjes tussen zitten hé ... nu heb ik met Karlijn eindelijk een geldig excuus.

Een extra dankjewel voor Klara, mijn carpool-maatje van tijd tot tijd. Je deed me twee keer nadenken voor ik iets zei, want anders werd ik erop gepakt door de eeuwig aanwezige psycholoog in jou. Klara, hopelijk wil je mijn gegrommel in het verkeer nog wat verder aanhoren.

In 2007 werd ons onderzoeksteam uitgebreid met een nieuwe psychiater, Inge Knuts. Inge, ik wens je veel succes met jouw promotie-traject. Binnen enkele jaren zitten we hier in de zaal, luisterend naar jouw verdediging. Dankjewel Inge voor al je hulp met de patiënten voor de $\mathrm{CO}_{2}$ scan studie. Door jou kreeg ik een mooi overzicht van welke patiënten konden en wouden deelnemen aan de studie, en wanneer en hoe ik ze kon bereiken.

Ook een dankjewel aan de andere AAC-teamleden. Ondanks het feit dat ik niet veel beneden kwam, hebben jullie er toch voor gezorgd dat ik me geen buitenstaander voelde. Vooral jullie bereidheid om een screening van mij te 
koppelen aan jullie afspraken heeft me enorm vooruit geholpen om op gang te geraken met de laatste studie. Thea en Judith, jullie waren, en zijn, hier vooral zeer goed in doordat jullie ook deel uitmaken van het onderzoeksteam. Dankjewel!

In deze high-tech tijden lijk je alleen maar vooruit te kunnen als je computer ook wil meewerken. Ik had nog al dikwijls ruzie met die van mij. Gelukkig hebben wij een flying doctor voor zulke problemen: Ron Mengelers, altijd en overal bereikbaar. Dankjewel Ron!

En zonder secretariaat draait de hele boel niet. Jolanda, Ine en Trees, dankjewel dat ik steeds kan binnenlopen met allerlei praktische vragen en ook voor een vlug babbeltje.

Voor het vervolledigen van dit werk heb ik veel tijd in Leuven doorgebracht. Ook daar waren er mensen die het werken aangenaam maakten. Frederik en Ilse, samen met Ron waren jullie mijn vaste lunchgenoten, en soms vervoegde Vincent ons nog. Vaak genoeg heeft er een extra broodje of soepje op jullie plateau gelegen. Bedankt voor alle leuke momenten de afgelopen jaren. Ilse, nog veel sterkte daar met die 2 mannen ;-). Silvia en Caroline, veel succes met jullie verdere stappen, maar dat zal wel geen probleem zijn. Judith, jij kwam er pas in mijn laatste jaar bij. Ik heb ontzettend genoten van jouw gezelschap in het Louvre. Gelijkaardig ervaringen op hetzelfde moment zorgden natuurlijk voor extra stof om te babbelen. Veel geluk met je gezinnetje en natuurlijk ook in het vervolledigen van je doctoraat! Sabine, bedankt dat ik van je bureau gebruik mocht maken op de dagen dat je er niet was.

Ook aan Leuvense zijde, maar niet in verband met MRI, gaat er een grote dankjewel uit naar Deb Vansteenwegen. Bedankt voor al je tijd en hulp met de conditionering. We hebben de studie uiteindelijk niet tijdig kunnen uitvoeren binnen mijn doctoraat, maar hopelijk komt het er wel nog van!

Also a special thanks to René Hurlemann. Dear René, I got to know you during this wonderful master seminar week in Florence. I admire your enthusiasm and passion for your research. Thank you for giving me the opportunity to perform research at the Forschungszentrum in Jülich. I'm looking forward to do more joint research in the future.

I couldn't have done the study in Jülich without the help of Juraj Kukolja. Dear Juraj, thank you very much for all you help. Because of you we were able to finish the study just in a very short period. Also thanks to Özgür Onur for your help with the figures and the resubmission.

Leni, lieve Leni, je staat hier speciaal op de overgang tussen werk aan de ene kant en vrienden en familie aan de andere kant. Dankjewel voor al je goede zorgen van de afgelopen jaren. Ik kon je altijd alles vragen, niets was te veel. Je denkt steeds aan de verjaardagen en je zorgt dat er af en toe 
wat lekkers op de tafel verschijnt, tijdens de mastervergaderingen of gewoon in de keuken. Kortom, je creëert een aangename huiselijke sfeer. Bedankt om met me mee te leven al deze jaren. Niet enkel in het promotietraject, maar ook de grote gebeurtenissen in mijn dagelijkse leven: bouwen, trouwen, ... . Dankjewel voor al je lieve attenties.

Niet alleen collega's zorgen dat je zulk werk tot stand kan brengen. De schwung waarmee je door je leven gaat wordt grotendeels bepaald door je achterban, je vrienden en familie. Dit reflecteert zich ook in je werk.

Mama, papa, hier sta ik dan. Eindelijk krijgen jullie het resultaat te zien van de afgelopen jaren. Jullie hebben altijd geweten dat ik het kon en er steeds in geloofd. Jullie steun was en is onmisbaar. Zelfs al bellen we maar vijf minuutjes op voorhand, of helemaal niet, er kan steeds een bordje bij geschoven worden als we het zelf te druk hebben om ook nog eens eten te maken. Ook de kleinkinderen zijn steeds welkom. Bedankt voor alles.

De vriendengroep zorgde voor de leuke ontspanning. Roel, Tessa, Annelies, Wouter, Birgit, Tim, Niels en Ellen, met jullie viel er elk weekend wel iets te beleven: van een gezellige zondagse pannekoek tot een BBQ-ke. Dat het nog lang zo mag blijven! Ik zou zeggen dat ik nu de tijd heb om op tijd te komen, ... maar ik ga geen valse beloftes maken (:).

Niels, we hebben samen geravot toen we klein waren, samen op kot gezeten, je bent mijn getuige geweest op 08-08-08, bijna gelijktijdig mama/papa geworden en nu vandaag sta je hier weer. Wat is het volgende ;-) ? Laten we hopen dat Lenne en Karlijn het even goed met elkaar kunnen vinden!

Purple girls en Vamos-mannen, mercikes voor de heerlijke tenniszomers.

Last but not least, Stijn. Ik zou hier oneindig veel woorden kunnen gebruiken, maar ik denk dat je wel weet dat je al die jaren mijn grootste steun bent geweest. Ik zie u graag!

En Karlijntje, lieve schat, jij bent ons grootste meesterwerk. Lieve kusjes en een dikke knuffel van mama! 

CURRI CULUM VITAE 
Liesbet Goossens was born on March 211981 in Hasselt, Belgium. In 1999, she graduated from secondary school at Humaniora Kindsheid Jesu (Hasselt, Belgium.

In September 1999 she started her studies in Biomedical Sciences at the Limburgs Universitair Centrum (now Hasselt University, Belgium) and obtained her candidate (bachelor) diploma in 2001. She continued her studies at the Catholic University Leuven (Belgium) from which she received her master diploma in Biomedical Sciences Cum Laude in June 2003. For this degree she performed a research internship at the department of radiology concerning functional MRI experiments. It was during this internship that she gained interest in performing research.

In October 2003 she started her PhD research at the School of Mental Health and Neurosciences (MHeNS, division Mental Health) of the Maastricht University. In the framework of this research, she performed several studies in cooperation with the Medical Imaging Research Center of the Catholic University Leuven (Belgium). From January to March 2008, she performed fMRI research at the Institute of Neurosciences and Biophysics of the Forschungszentrum Jülich, Germany.

Since December 2003 she works as academic coordinator for the professional International Master of Affective Neurosciences of the MHeNS (Maastricht University, The Netherlands).

Following the defence of the present thesis, the author will continue her work as academic coordinator. Furthermore, she has obtained a one-year postdoc position in order to develop further research projects on fear and safety learning. 


\section{Papers}

L. Goossens, K. Schruers, R. Peeters, E. Griez, S. Sunaert. Visual presentation of phobia-relevant stimuli results in activation of the amygdala via an extrageniculostriate pathway. Psychiatry Research. 2007 Jul 15; 155(2):113-20.

L. Goossens, S. Sunaert, R. Peeters, E. Griez, K. Schruers. Amygdala Hyperfunction in phobic fear normalizes after exposure. Biological Psychiatry. 2007 Nov 15; 62(10): 1119-25.

L. Goossens, J. Kukolja, O.A. Onur, G.R. Fink, W. Maier, E.J.L. Griez, K. Schruers, R. Hurlemann. Selective processing of social stimuli in the superficial amygdala. Accepted for publication in Human Brain Mapping (2009)

L. Goossens, K. Schruers, R. Peeters, E. Griez, S. Sunaert. Evidence for changes in brain connectivity following single session behavioural therapy. Submitted

K. Schruers, G. Esquivel, MA. Van Duinen, M. Wichers, G. kenis, A. Colasanti, I. Knuts, L. Goossens, N. Jacobs, J. van Rozendaal, J. Van Os, E. Griez. Genetic moderation of $\mathrm{CO} 2$ induced negative affectivity. Submitted

\section{Abstracts \& Posters}

L. Goossens, S. Sunaert, R. Peeters, P. Van Hecke, K. Schruers. Functional MRI of simulated deception. The International Journal of Neuropsychopharmacology. 2004; 7 suppl.1: 305

M. Van Duinen, K. Schruers, M. Maes, L. Goossens, E. Griez. Possible gender differences in cortisol levels in panic disorder. The International Journal of Neuropsychopharmacology. 2004; 7 suppl.1: 199.

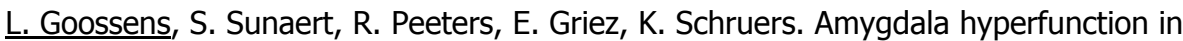
phobic fear normalizes after exposure. Poster op Instituutsdag Hersenen \& Gedrag 2007

\section{Book Chapter}

E. Griez, L. Goossens, K. Schruers. The two faces of anxiety. In: M.I. Botez. Neuropsychologie clinique et neurology du comportement. Montréal: Les presses de I'Université de Montréal (2005) 